\title{
الاستفادة هن أسلوبي الطباعة والتطريز في إثراء زخارف الفن الشعبي لملابس الأطفال"
}

إعلاد

$$
\begin{aligned}
& \text { أ. د / رشا عباس محمد متولمسل الجموهريح } \\
& \text { أستاذ الملابس والنسيج }
\end{aligned}
$$

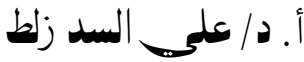

$$
\begin{aligned}
& \text { أستاذ النسيج والملابس المتفرغ } \\
& \text { كلية التربية النوعية- جامعة المنصورة } \\
& \text { وكيل شئون التعليم والطلاب السابق } \\
& \text { كلية التربية النوعية- جامعة المنصورة } \\
& \text { أ.م.ده/ نورا حسر. العدوكي } \\
& \text { أستاذ النسيج والملابس المساعد } \\
& \text { كلية التربية النوعية- جامعة المنصورة }
\end{aligned}
$$

مجلة بحوث التربية النوعية ـ جامعة المنصورة

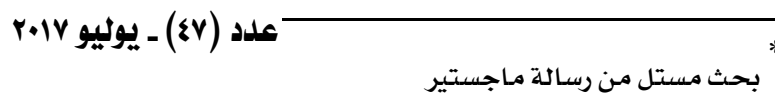


تتجه ملابس الأطفال ِِْ مرحلة الطفولة المتوسطة ِِِ الآونة الأخيرة إلى التقليد الغربي

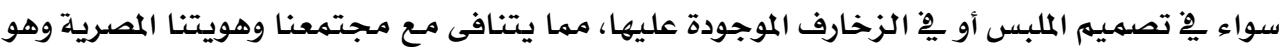

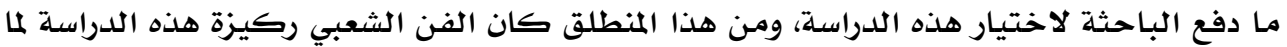

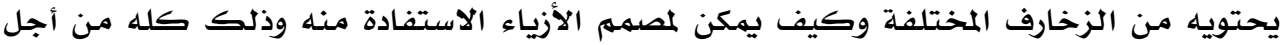
النهوض بصناعة الملابس ولتتمية الحس الجمالي والحفاظ على هويتنا المصرية.

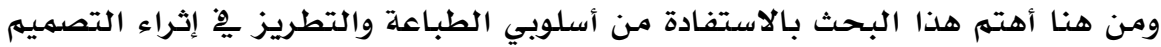

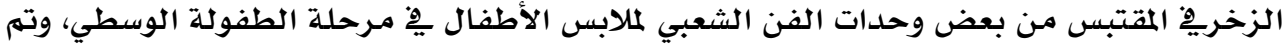

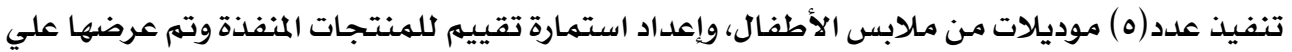

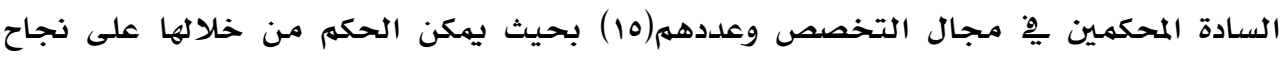
التصميمات المنفذة ،وكذلك تم إعداد استمارة تقييم المنتجات للمستهلكين من الأمهات وعددهينم

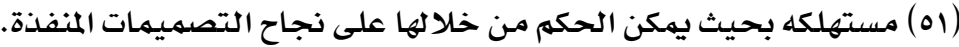
وتوصل البحث إلى أنه: توجد فروق ذات دلالة إحصائية بين الموديلات المنفذة ِِّ تحقيق

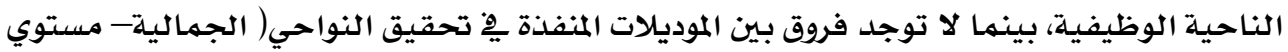

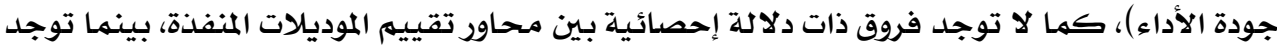

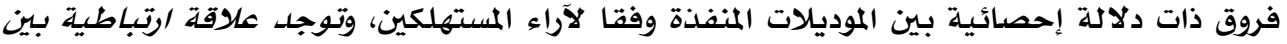

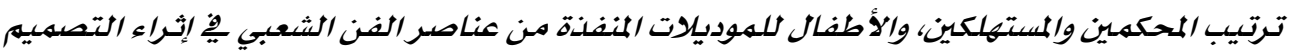
الزخربِ لمابس الأطفال.

*أستاذ النسيج والملابس المتفرغ وكيل شئون التعليهم والطلاب السابق - كلية التربية النوعية- جامعة المنصورة

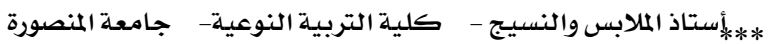

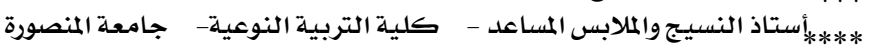

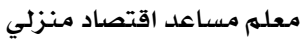


إن حضارة الأممر والشعوب لا تقاس بما لديها من تطور علمي وتقني واقتصادي بل تقاس بما يوجد فيها من إرث وتاريخ زاخر بالتراث، وقدرة أبناءها على المحافظة على هلى هذا الإرث وتحديثيث. والفن الشعبي هو روح الثقافة الأصلية النقية لشعب ما، كما إن الفن الشعبي لغة عالمية

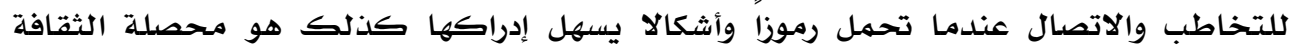

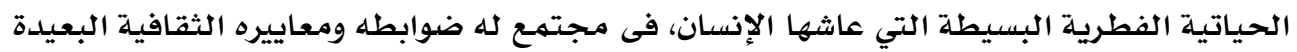

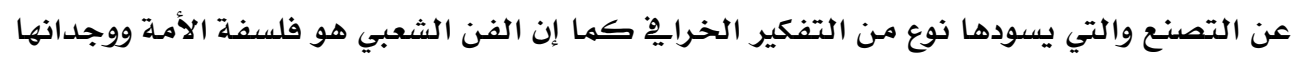
ونبضها الحقيقي (يوسف خليفة ونجوى حسين، ب. ب. r). والملبس يعتبر من أهم العوامل المؤثرة على نمو الطفل الجسمي والنفسي والاجتماعي، لذا

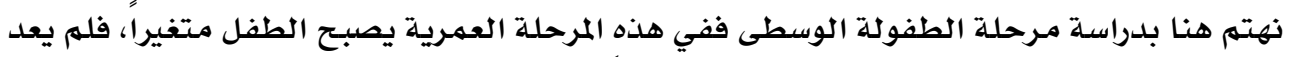

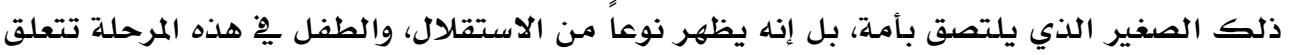

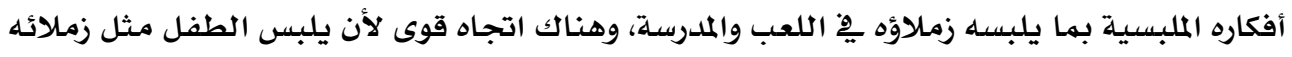

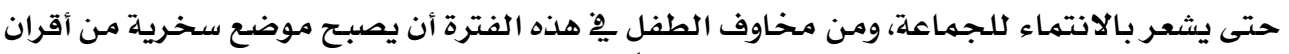

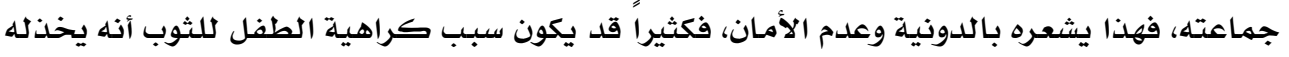

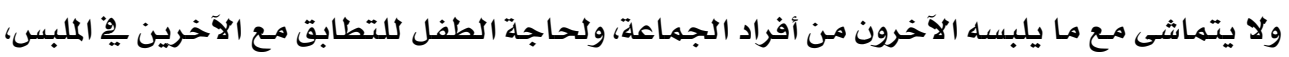

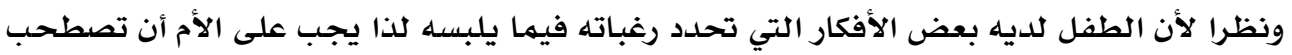

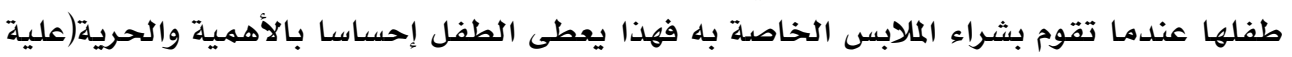

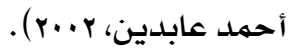

فالطفل فى مرحلة الطفولة الوسطى من(ب:9) سنوات يحاول اتخاذ قراراته الملبسية بنفسـه

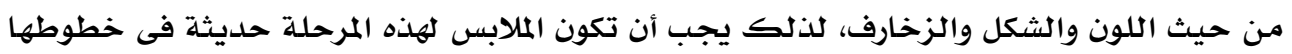

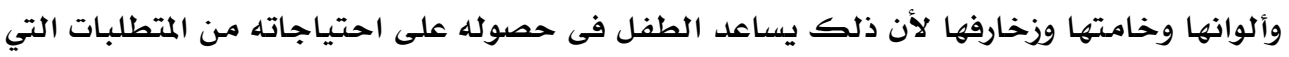

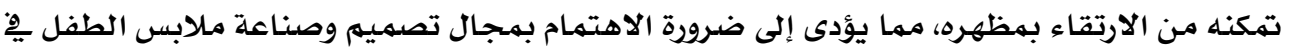

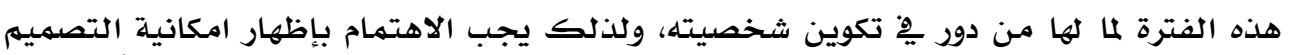

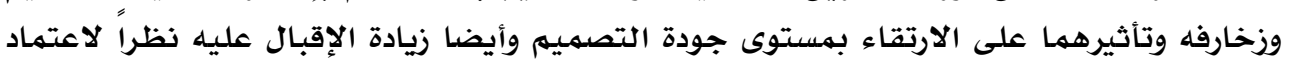

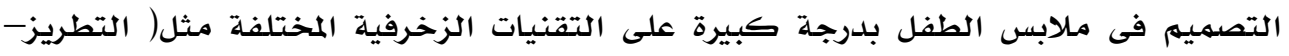

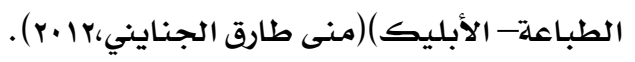

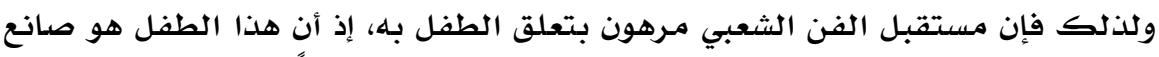

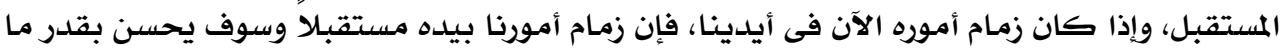

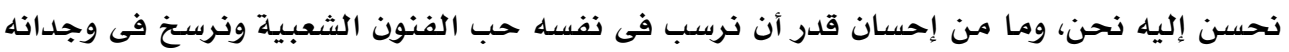

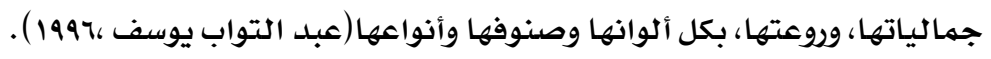


مجلة بحوث التربية النوعية - علدد

لذلك فقد اهتهم البحث باستخدام مجموعة من الوحدات الزخرفية من الفن الفنات الشعبي

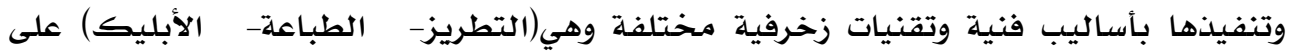

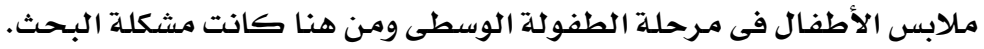

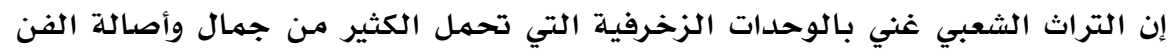

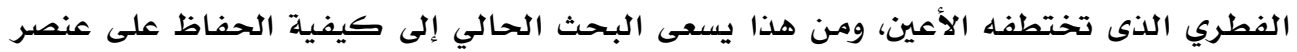

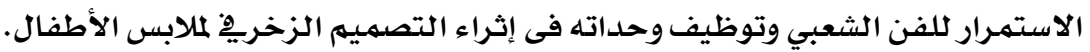
ويناء عليه يمكن تحديد مشكلة البحث فى التساؤل الرئيس التالي:ما إمكانية الاستفادة من أسلوبي( الطباعة- والتطريز) فى إثراء التصميه الزخريف

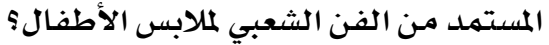

\section{ويتفرع من هذا التساؤل أسئلة فرعية كما يلي:-}

ا. ما إمكانية الاستفادة من أسلوب الطباعة يِّ إثراء زخارف الفن الشعبي لمابس الأطفال هِيْ

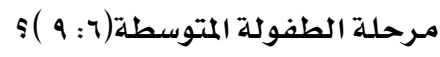

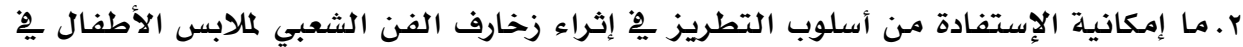

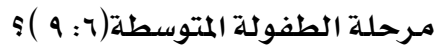

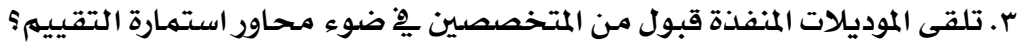

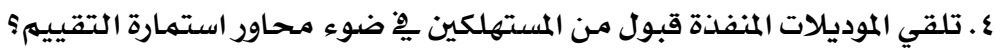

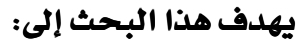

ا.التعرف على الفن الشعبي المصري وجمالياته وأشكاله المنتقاة وعلاقتها بإثراء التصميم الزخريِ لملابس الأطفال.

ץ.التعرف على التقنيات التي تثري التصميم الزخريفّ" الفن الشعبي" لمابلابس الأطفال فى مرحلة

$$
\text { الوسطى من (7: 9: ) سنوات. }
$$

ب.التأكيد علي جماليات أسلوبي(الطباعة- التطريز) والاستفادة منهما يِّ إثراء أزياء الأطفال.

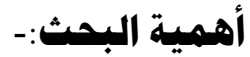

$$
\text { تتركز أهمية البحث فى النقاط التالية:- }
$$

ا.إعداد تصميمات زخرفية مستمدة من الزخارف الشعبية المصرية لإثراء الجانب الجمالي

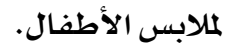

r. إثراء الجانب الجمالي لملابس الأطفال باستخدام زخارف الفن الشعبي المطبوعة والمطرزة.

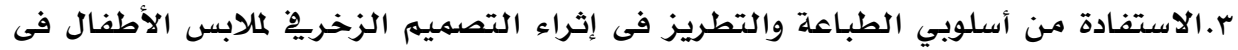

$$
\text { مرحلة الطفولة الوسطى من (7: 9) سنوات. }
$$




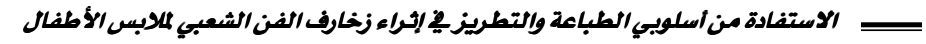 \\ فروض البحث:}

ا. توجد فروق ذات دلالة إحصائية بين الموديلات المنفذة يْ تحقيق الناحية الوظيفية وفقا لآراء

المحكمين.

r.توجد فروق ذات دلالة إحصائية بين الموديلات المنفذة ِِّن تحقيق الناحية الجمالية وفقا لآراء

المحكمـين.

r.توجد فروق ذات دلالة إحصائية بين الموديلات المنفذة يِّ تحقيق مستوي الجودة وفقا لآراء

المحكمين.

ع . توجد فروق ذات دلالة إحصائية بين الموديلات المنفذة وفقا لآراء المحكمين.

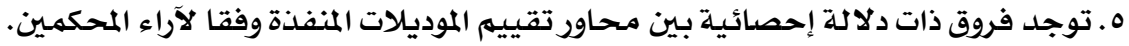

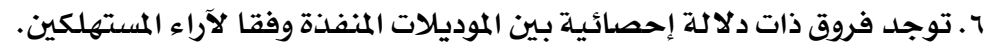

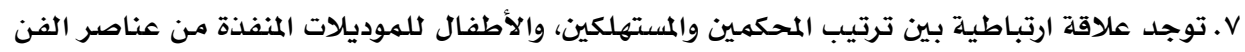

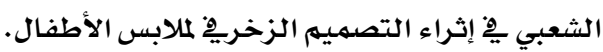

هدود البمث:-

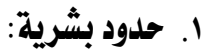

أ- الأطفال(البنات ) في مرحلة الطفولة الوسطى من (7 إلى 9 ) ) سنوات.

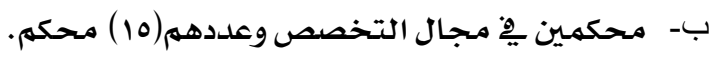

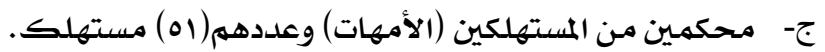
r. أسلوب الطباعة اليدوية: (طريقة الرسمى المباشر).

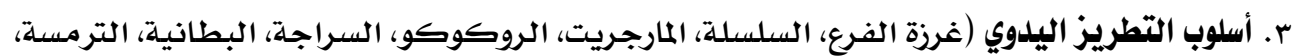

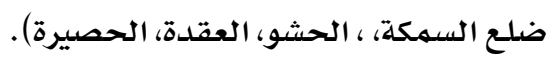

\section{أدوات البحث:}

ا. استمارة تقييي الموديلات المنفذة موجهه للمتخصصين في مجال التخصص، واحتوت الاستمارة على مجموعة

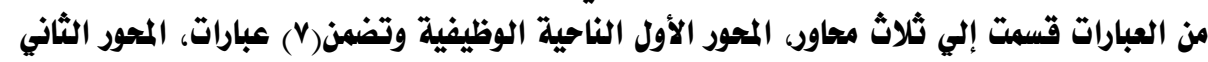

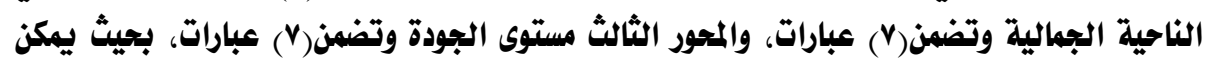

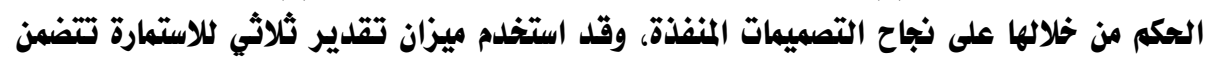
ثلاث مستويات للإجابة وهي( موافق، موافق إلى حلد ما، غير موافق) بحيث تعطي الإجابة على موافي ثلى ثلاث

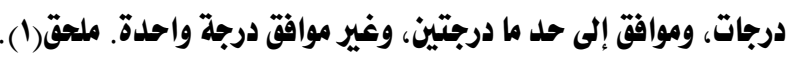

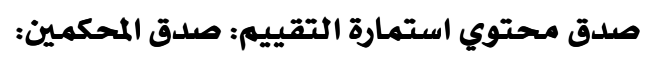

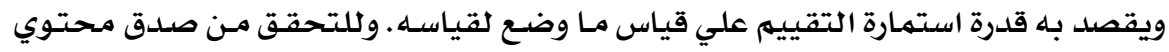

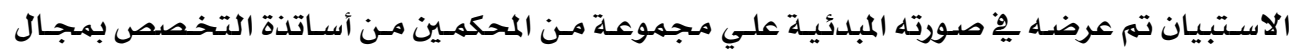

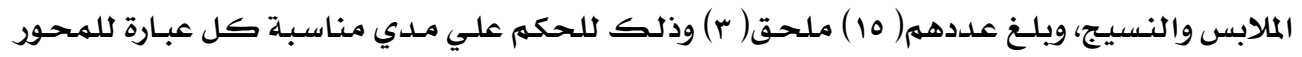




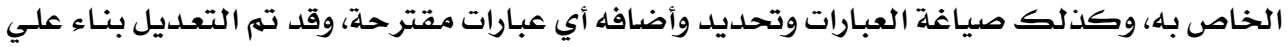

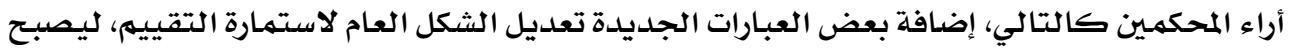

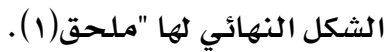
الصدق باستخدام الاتساق الداخلي بين الدرجة الكلية لكل محوروالدرجة الكلية لاستمارة التقييم: تم حسـاب الـصدق باسـتخدام الاتسـاق الــاخلي وذلـك بحســاب معـامـل الارتبـاط (معامـل ارتباط بيرسون) بين الدرجة الكلية لكل محور (الناحية الوظيفية، الناحية الجمالية، مستوى الجية الجودة)

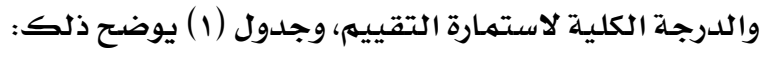
جدول(1) : قيم معاملات الارتباط بين درجة كل محورودرجة استمارة التقييم

\begin{tabular}{|c|c|c|}
\hline 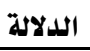 & الارتباط & \\
\hline$\cdot,+1$ & $\cdot, \mathrm{va}$ & المحور الأول: الناحية الوظيفية \\
\hline$\cdot, \cdot 1$ & $\cdot, \wedge 1$ & المحور الثاني: الناحية الجمالية \\
\hline$\cdot, \cdot 1$ & $\cdot, \wedge \varepsilon$ & المحور الثالث: مستوى الجودة \\
\hline
\end{tabular}

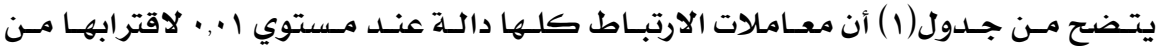

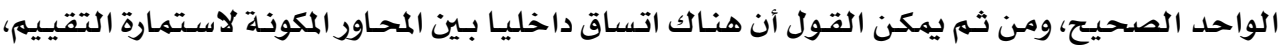

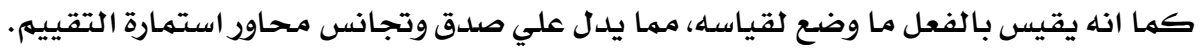
اختبار ثبات استمارة التقييم:

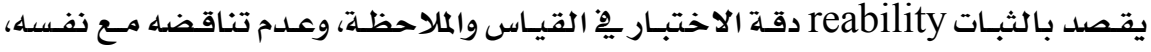

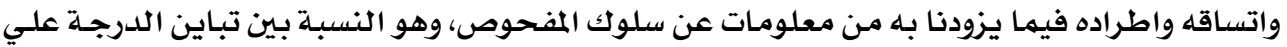

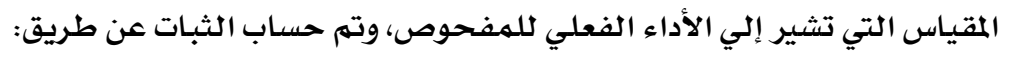

Alpha Cronbach المعامل ألفا كرونباخ

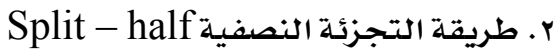

\begin{tabular}{|c|c|c|}
\hline التجزئة النصفية & معامل ألفا & \\
\hline$\cdot, A Y I \ldots, Y \leqslant Y$ & •, Yor & المحور الأول: الناحية التصميمة \\
\hline$\bullet, \wedge$ • _-, А५• & $\cdot$, A & المحور الثاني: الناحية الجمالية \\
\hline$\cdot, \wedge \vee r \_-, \wedge \leqslant 0$ & - AVO & المحور الثاثث: الناحية الوظيفية \\
\hline$\cdot, \Lambda 7 r-\cdot, \Lambda \cdot 0$ & $\cdot$, Arr & ثبات استمارة التقييي ككل \\
\hline
\end{tabular}

يتضـح مـن جـدول(r ) أن جميـع قيم معـاملات الثبـات، معامـل ألفـا، التجزئــة النصفية، دالـة

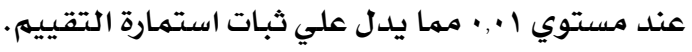


r. استمارة تقييه منتجات البحث موجه للمستهلكين(الأمهات)، واحتوت الاستمارة علي(Iا) عبارة، بحيث

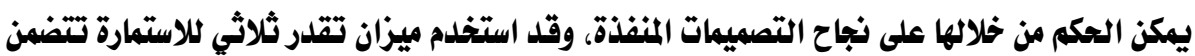

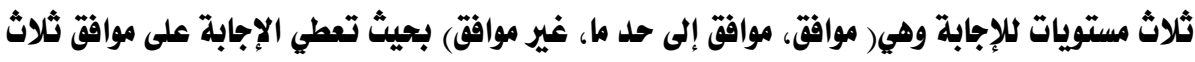

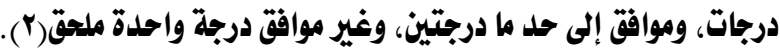
صدق محتوي استمارة التقييه: صدق المحكمين:

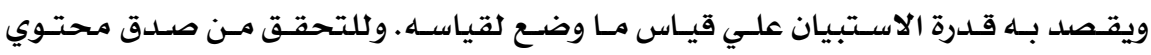

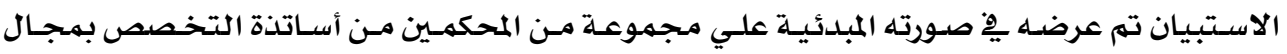

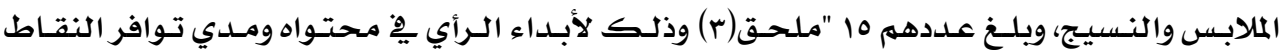

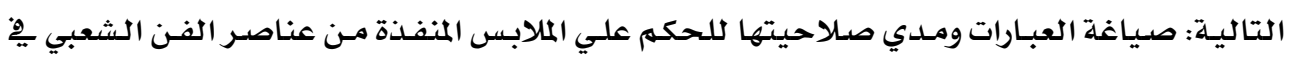
إثراء التصميه الزخريخ لملابس الأطفال.

الصدق باستخدام الاتساق الداخلي بين درجة كل عبارة والدرجة الكلية لاستمارة التقييم:

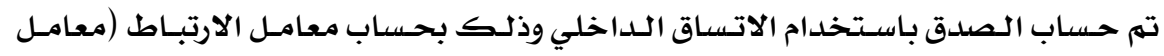

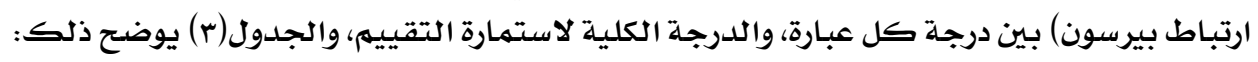
جدول(r): قيم معاملات الارتباط بين درجة كل عبارة ودرجة استمارة التقييم

\begin{tabular}{|c|c|c|}
\hline الدلالة & الارتباط & العبارة \\
\hline$\cdot, \cdot 1$ & $\cdot, \wedge \leqslant 0$ & 1 \\
\hline$\cdot, \cdot 1$ & - „A9r & $r$ \\
\hline$\cdot, \cdot 1$ & $\cdot, 107$ & $r$ \\
\hline$\cdot, \cdot \cdot$ & $\cdot, \wedge 0 \varepsilon$ & $\varepsilon$ \\
\hline$\cdot, \cdot 1$ & $\cdot, \wedge \leqslant 7$ & 0 \\
\hline$\cdot, \bullet \xi 0$ & $\cdot, \wedge 1$. & $y$ \\
\hline$\cdot, \cdot 0$ & - 1999 & $r$ \\
\hline •, & - ATr & $\Lambda$ \\
\hline$\cdot, \cdot 1$ & $\cdot$, Arr & 9 \\
\hline$\cdot, \cdot 1$ & $\cdot, \wedge 0$. & 1. \\
\hline$\bullet,+1$ & $\cdot, \wedge 7 \varepsilon$ & 11 \\
\hline
\end{tabular}

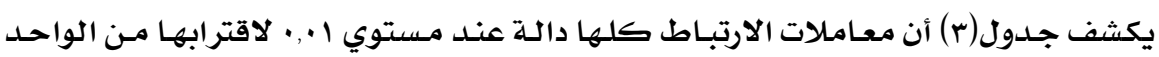

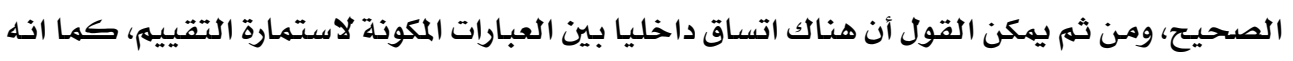

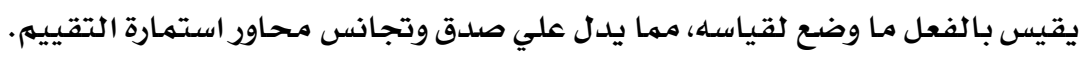




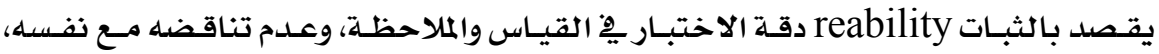

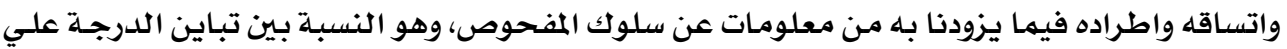
المقياس التي تشير إلي الأداء الفعلي للمفحوداده، وتهن معلومات عنس سلوكاب الثبات عن طريق: ا ـ معامل ألفا كرونباخ Alpha Cronbach Split - half r طريقة التجزئة النصفية جدول(ع): قيم معامل الثبات لمحاور استمارة التقييم

\begin{tabular}{|c|c|c|}
\hline التجزئة النصفية & معامل ألثا & \\
\hline$\cdot, \wedge 9 r_{-}, \wedge \leqslant r$ & $\cdot, \wedge \leqslant 0$ & ثبات استمارة التقييي ككل \\
\hline
\end{tabular}

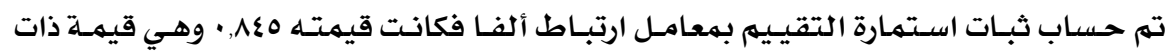

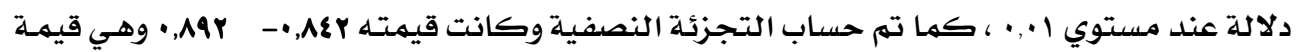

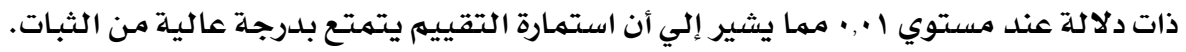

\section{إبراs|ت البمث:}

I. تحديد الموديلات التي سوف يتهم تنفيذها وعددها خمس موديلات.

r. تحديد العناصر الزخرفية الشعبية وطرق توزيعها على الموديلات.

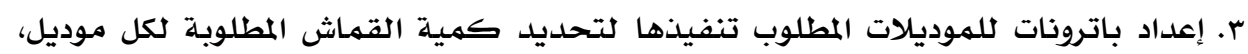
وشراء القماث اللازم لكل موديل. ع. قص الموديلات وطباعة التصميم الزخربِّ على الموديالات وتحديد الأساليب المناسبة للكل موديل

$$
\text { وتصميم زخريِ. }
$$

ه. استخدام أسلوب الطباعة بطريقة(الرسهم المباشر ) واختيار الألوان الطباعة المناسبة للتصميم

$$
\text { الزخريف. }
$$

7. استخدام غرز التطريز المناسبة واختيار نوع الخيوط المناسبة للغرزوالخامـة وألوانها.

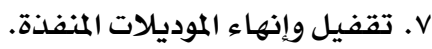


جدول(ه ) يوضح توصيف الموديلات المنفذة بتقنيات (الطباعة والتطريز).

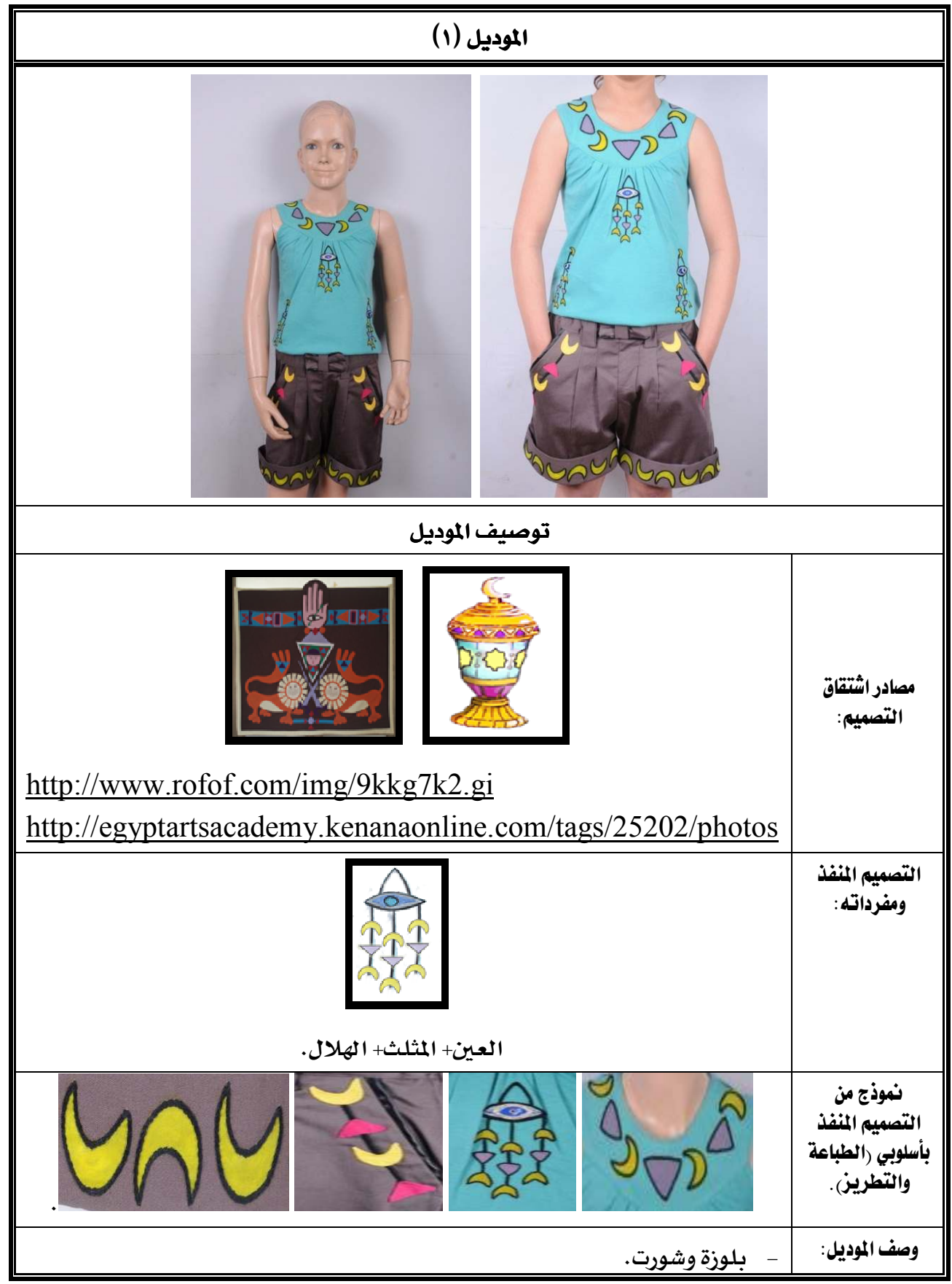


مجلة بحوث التربية النوعية - عدد

البلوزة كت بسفرة أمامية وخلفية موزع على السفرة بالتبادل بين وحدتي

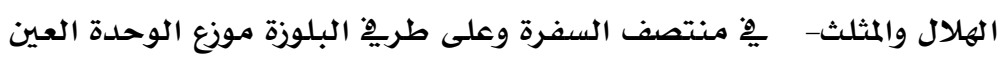
والهلال والمثلث.

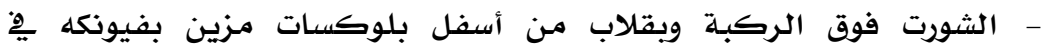

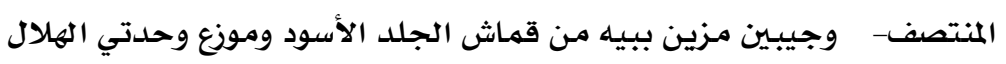

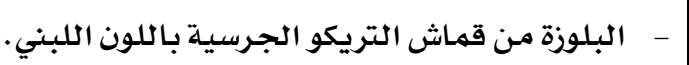

$$
\begin{aligned}
& \text { الشورت من قماش الجبر دين باللون الرمادي. }
\end{aligned}
$$

الخامة واللون:

قمماث من الجلد باللون الأسود لعمل بيه للجيب الجيب والفيونكة.

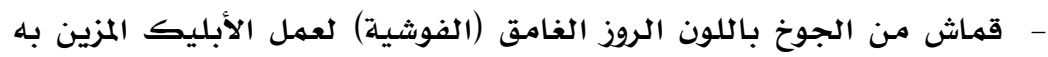

$$
\text { جانبي الجيب. }
$$

قماش التريكو الجرسية باللون الأصفر لعمل الأبليك المزين به جانبي الجيب.

$$
\text { أسلوب التنفيذ: }
$$

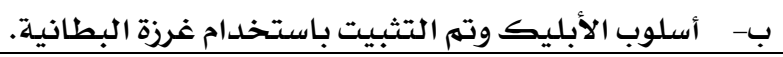

$$
\text { أولاً: الأدوات والخامات الخاصلة بالطباعة: }
$$

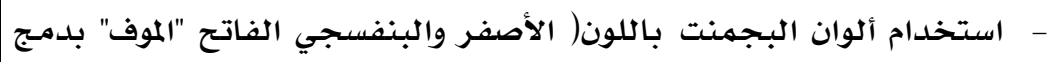

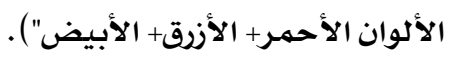

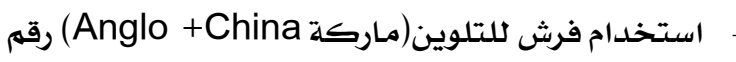

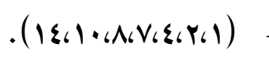

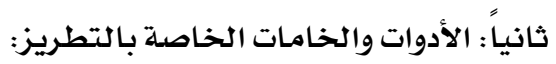

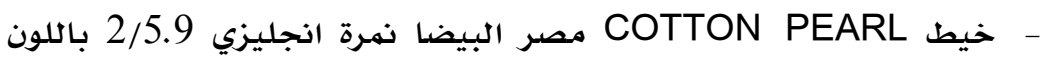

$$
\text { الأسود والأصفر. }
$$

خيط مالونية (DMC) باللون الأزرق الفاتح "اللبني" رقم . - ـــ.

$$
\text { إبرة للتطريز من معدن الصلب نهمرة } 7 .
$$




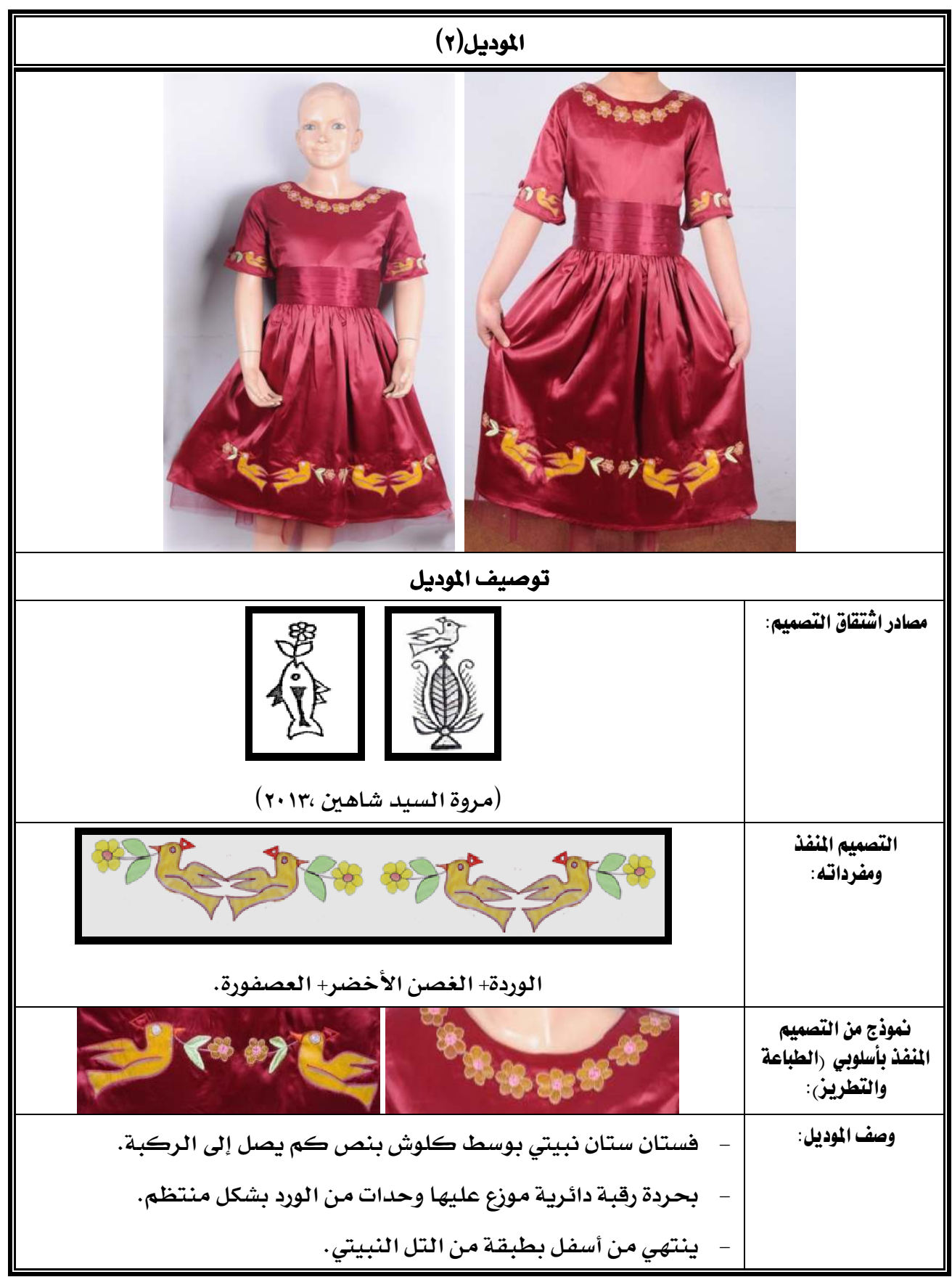




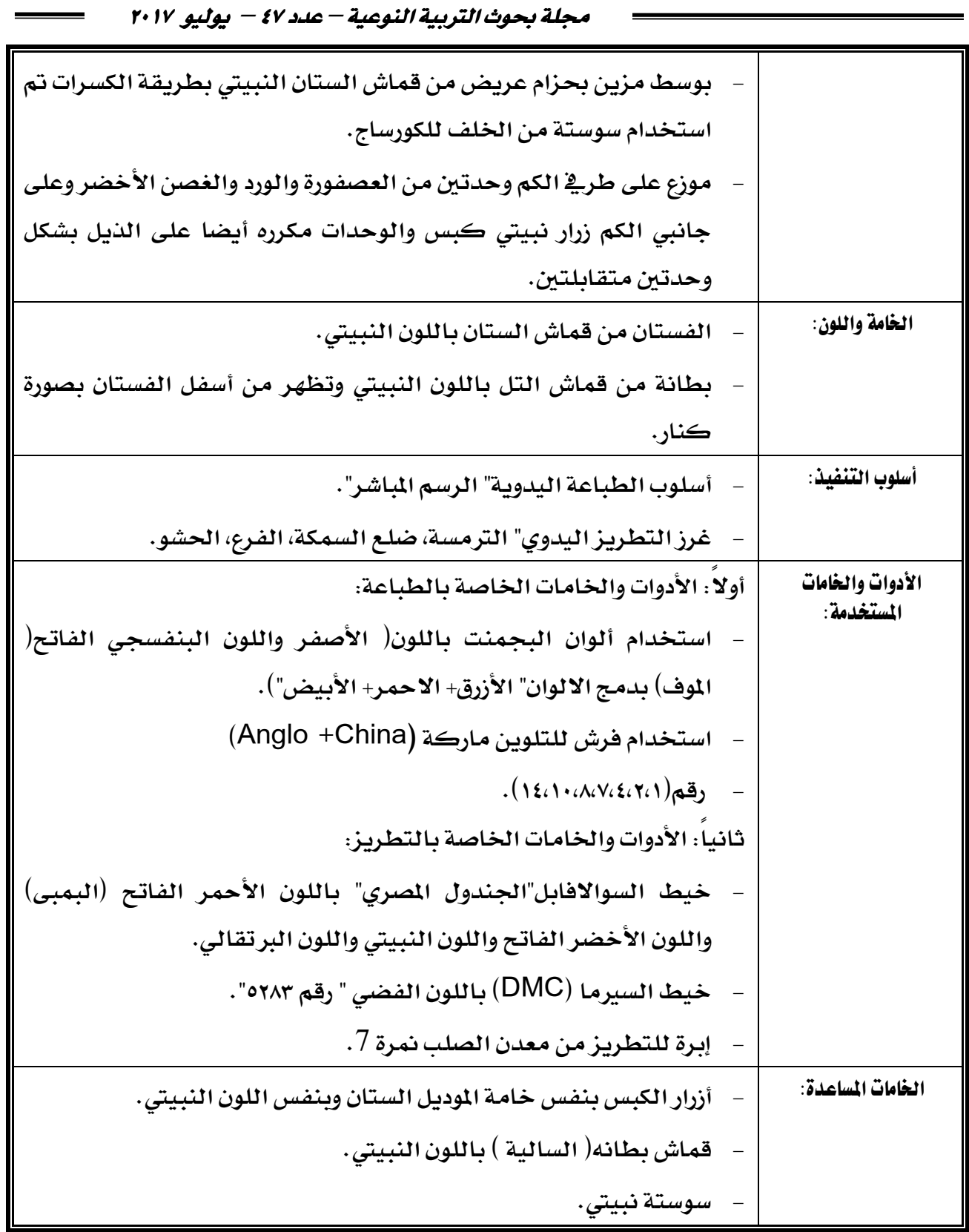




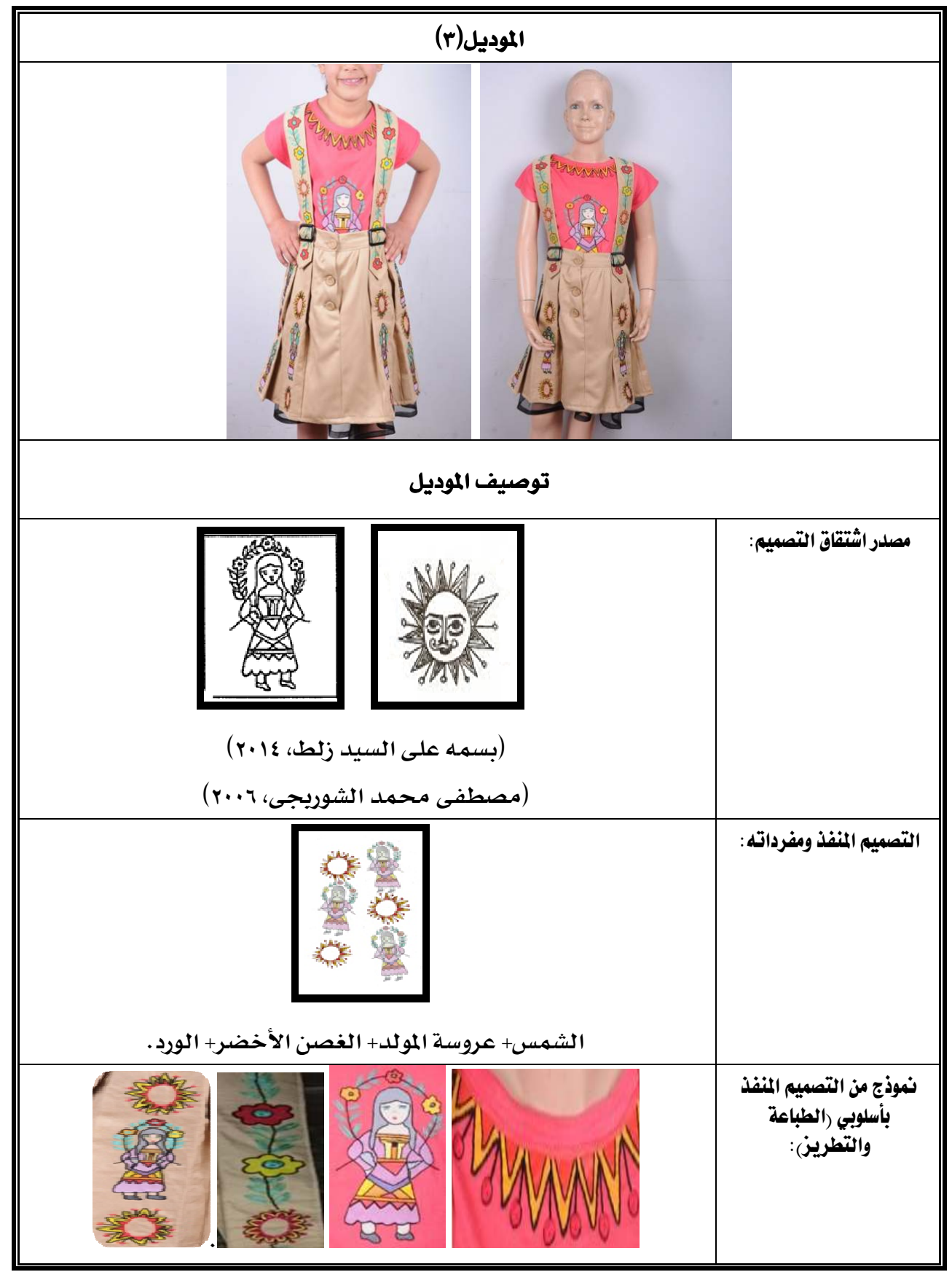




\begin{tabular}{|c|c|}
\hline 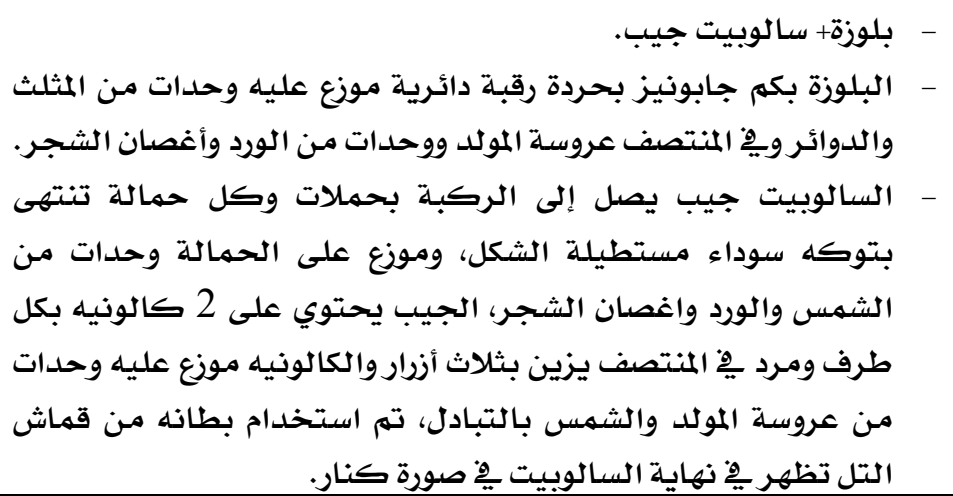 & وصف الموديل: \\
\hline 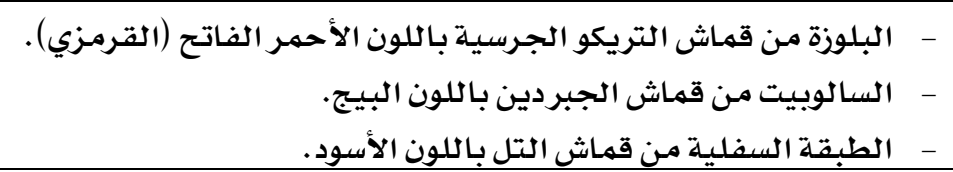 & الخامة والللون: \\
\hline - - غرز التطربز الطباعة اليدوية" الرسمى المباشر". & أسلوب التنفيذ: \\
\hline 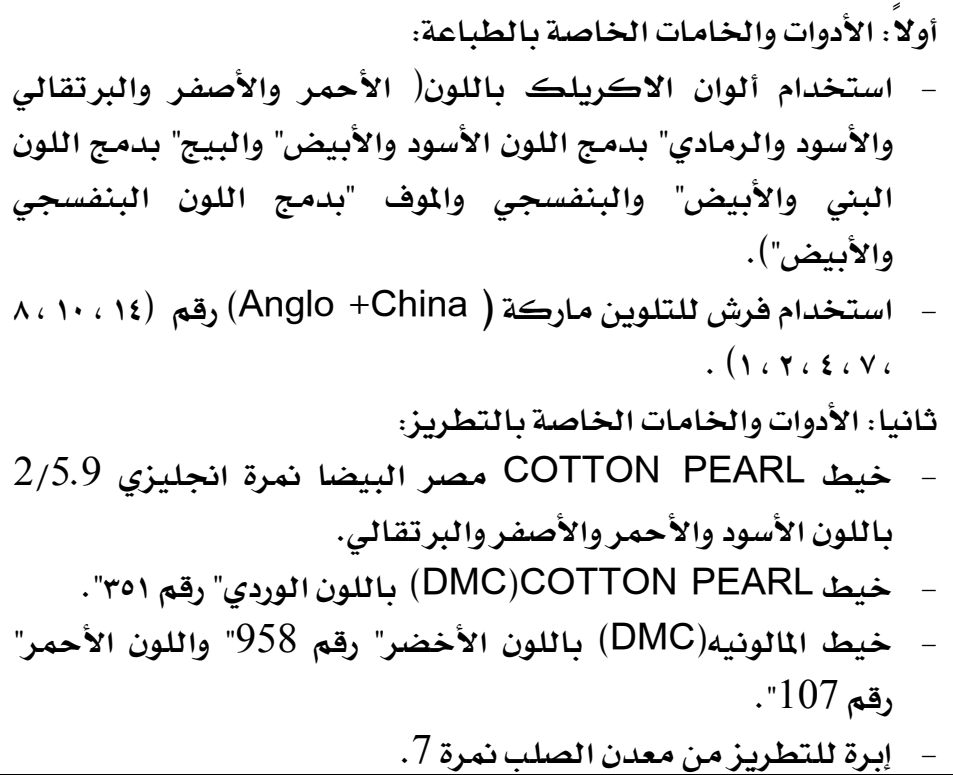 & 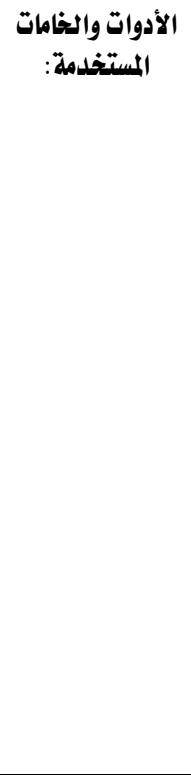 \\
\hline - - - - أزرار دائرية باللون البيجج. & الخامات المساعدة: \\
\hline
\end{tabular}




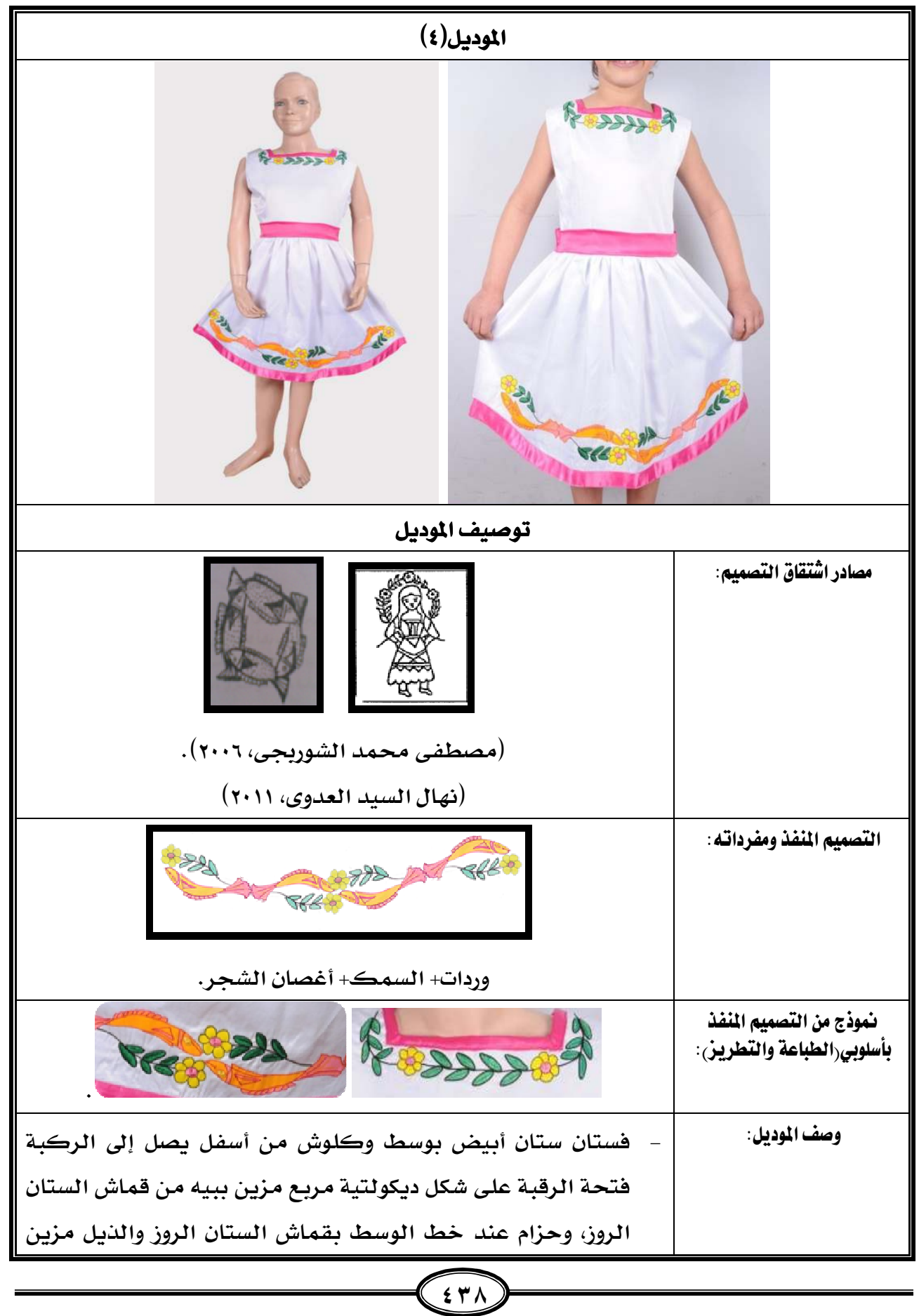




\begin{tabular}{|c|c|}
\hline 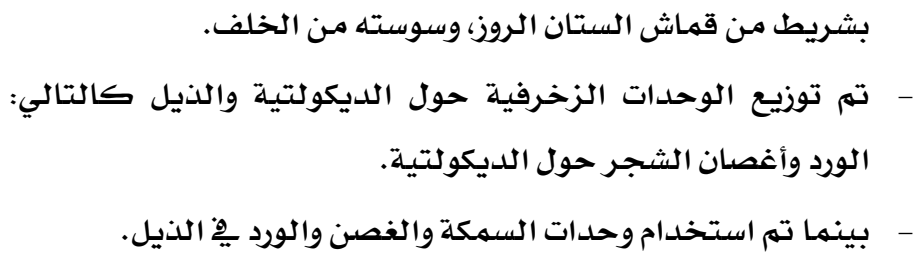 & \\
\hline - - الفستان من قماش الستان باللون الأبيض. & الخامة واللون: \\
\hline - - أسلوب الطباعة اليدوية"' الرسهم المباشر". & أسلوب التنفيذ: \\
\hline 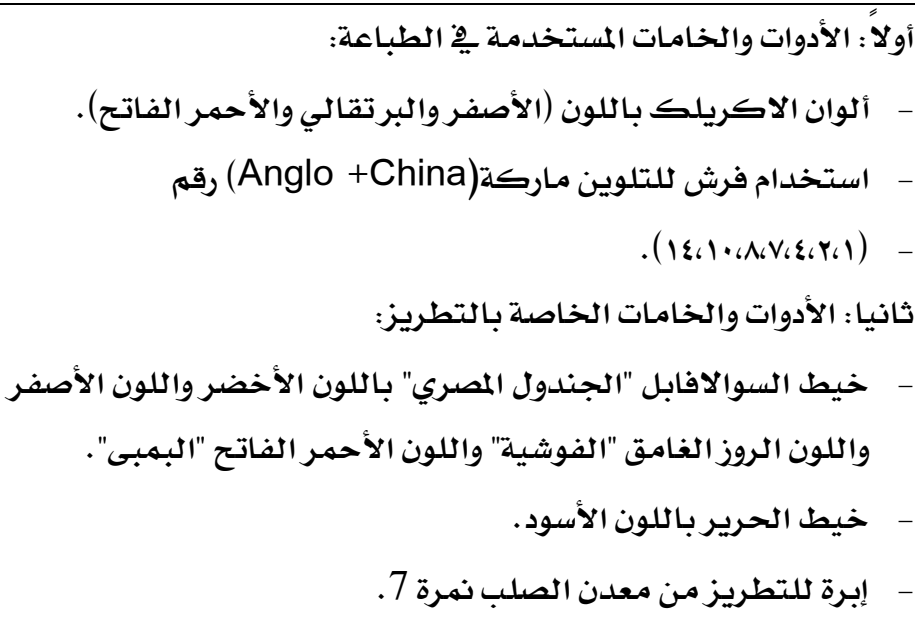 & الأدوات والخامات المستخدمة: \\
\hline - - - مهاش بطانة سالية باللون الأبيض. & 8ـ الخامات المساعدة: \\
\hline
\end{tabular}




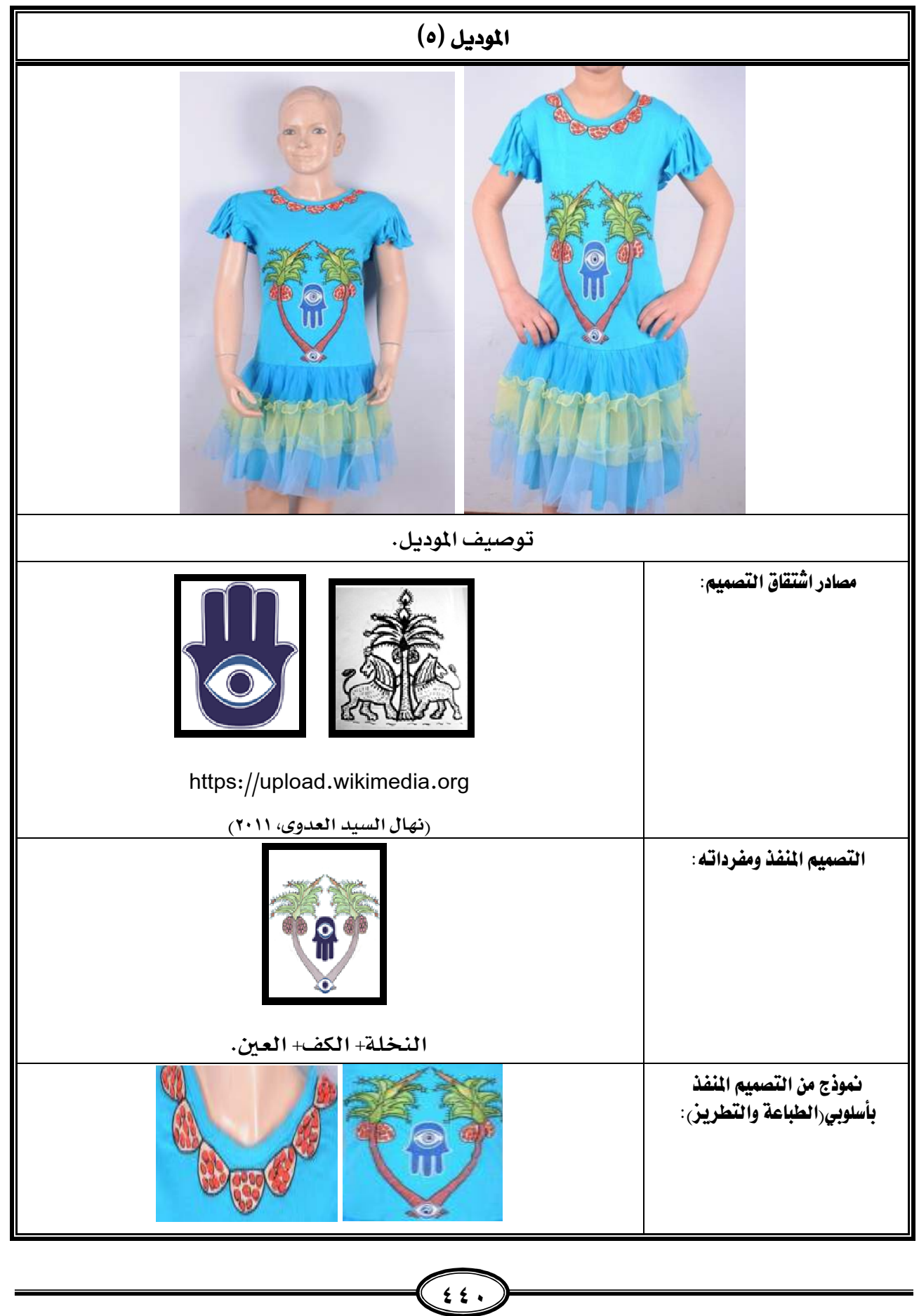




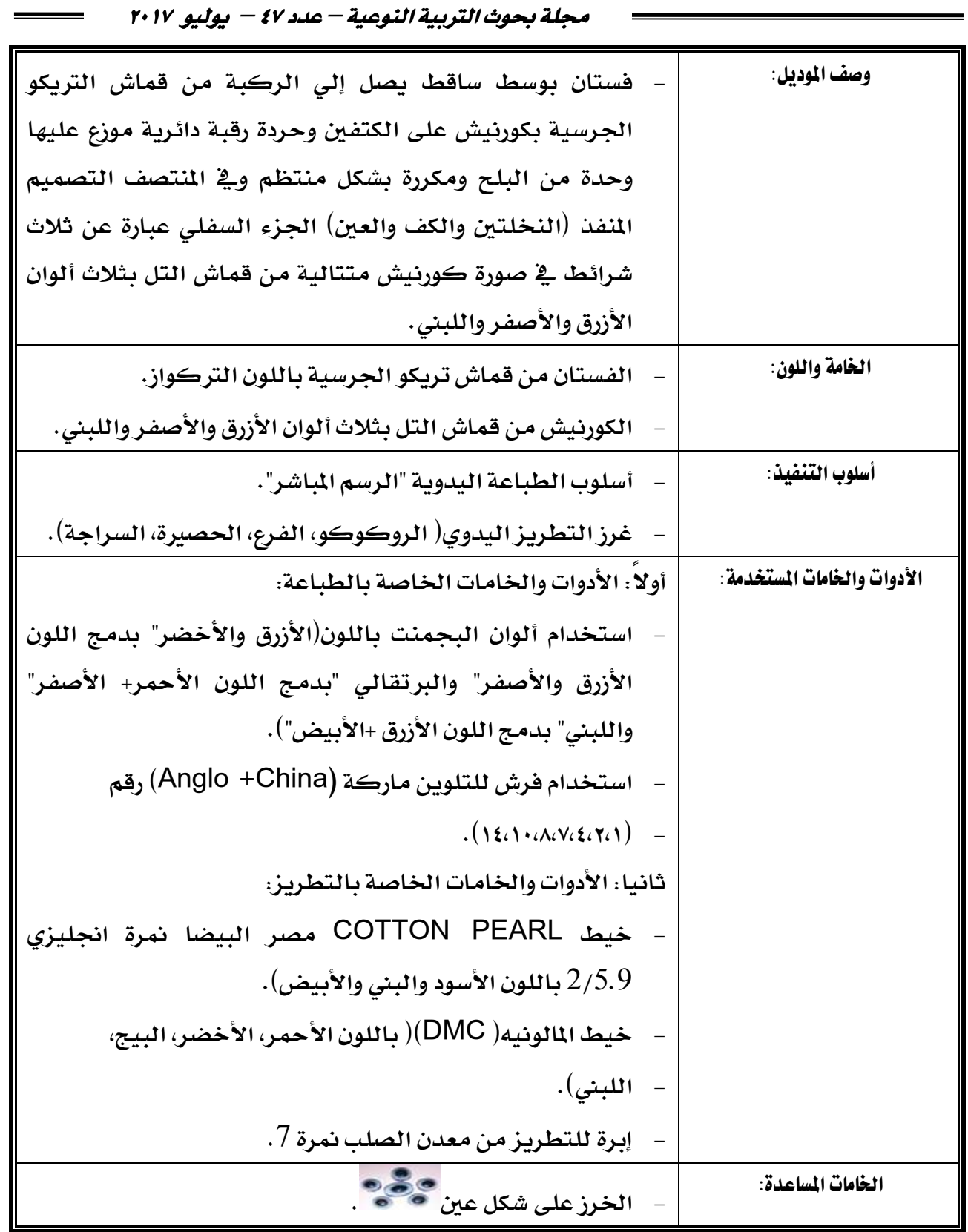

^. إعداد استمارة تقييم لتقييم الموديلات المنفذة من قبل المحكمين.

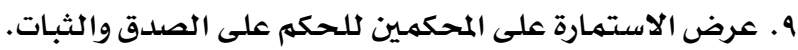

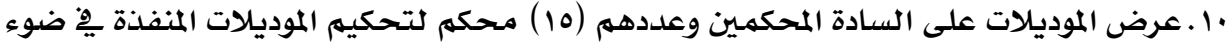

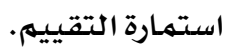


ا إ إعداد استمارة تقييم للمستهلكين( الأمهات) لتقييم الموديلات المنفذة.

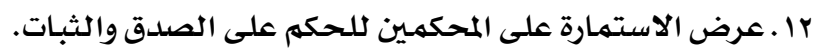

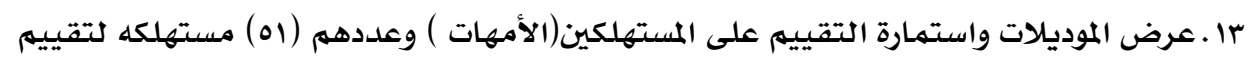
الموديلات المنفذة.

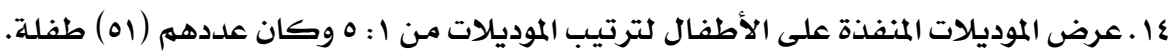

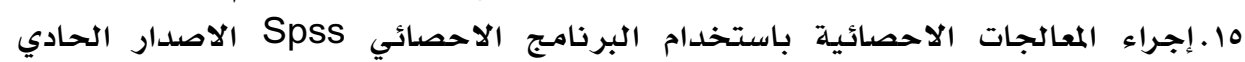
والعشرون(حسن عوض الجندي، ؟اء ·r). منههج البحث: المنهج الوصفي والتجريبي. همطات البمث:

ا ـ الفن الشعبي: Folk Art" هو الفن النقي المرتبط بفكر ووجدان شعب ما ويعبر عن هويته الثقافية المتراكم رصيدها

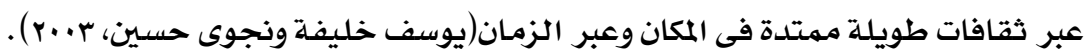
والفن الشعبي هو فن فطري يخضع لتقاليد متوارثة عبر الأجيال ويقوم بـه أناس من عامـة

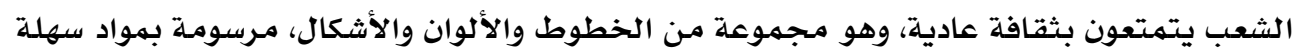

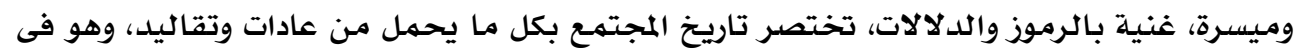

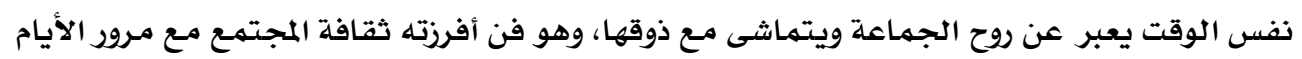

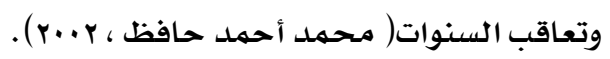

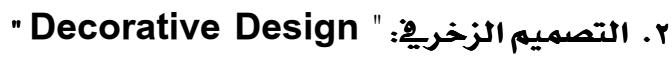

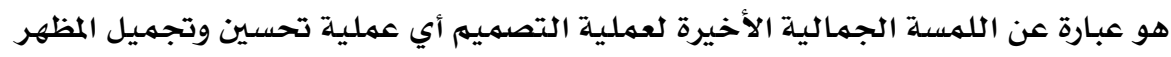

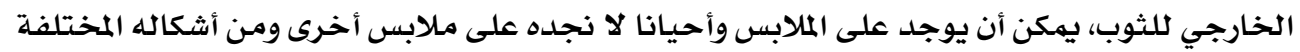

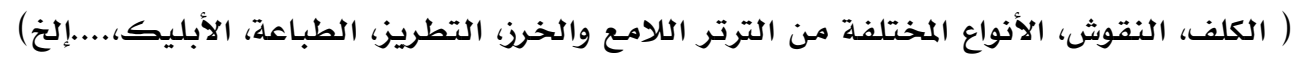

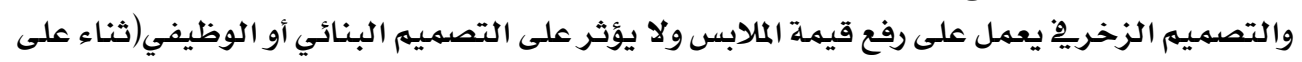

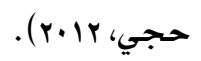

" Clothes " الملابس: "

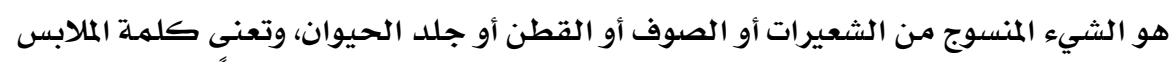

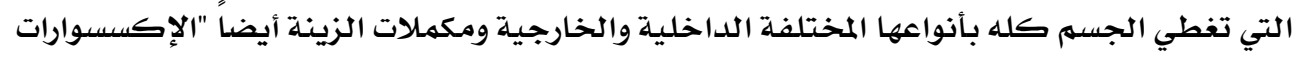

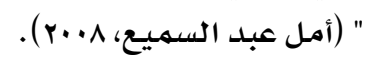




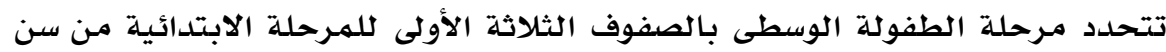

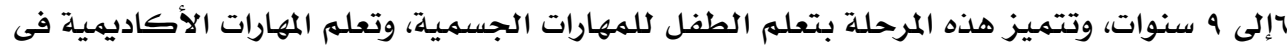

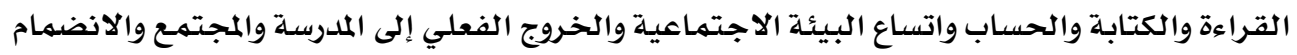

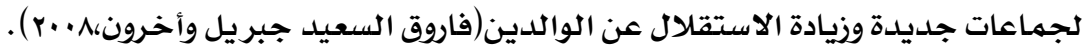

هـ التطريز:"Embroidery"

التطريز اسه أعجمي مشتق من الكلمهة الفارسية( ترازيدان) وهو مرادف الكلمسة الإنجليزية Embroidery

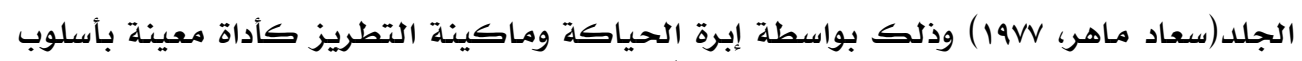

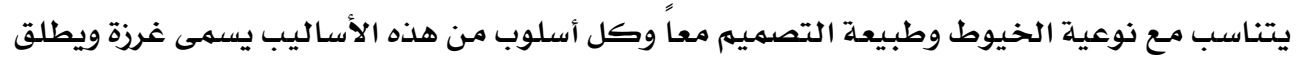

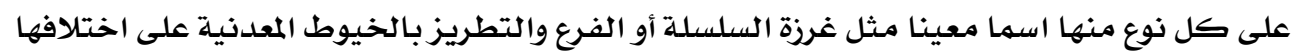
يسمى (زركشة) والفعل يزركش.

7.

يطلق مصطلح طباعة المنسوجات على العمليات التي تجرى على الخامـات النسجية بقصد

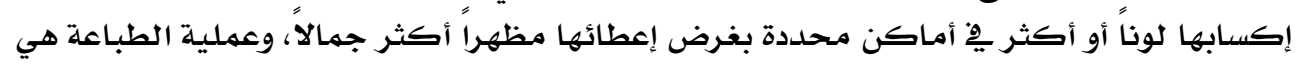

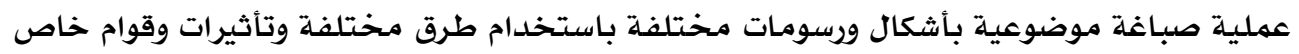

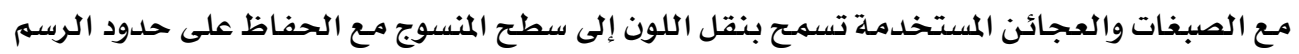

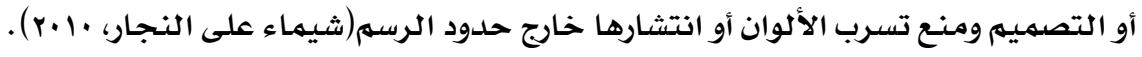

الدراسات السابقة:

تنقسم الدراسات السابقة إلى ثلاث محاور هما:• • أولا : دراسات اهتمت بالفن الشعبي.

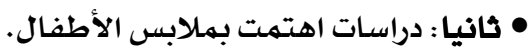
• • ثالثا: دراسات اهتمت بالتصميم الزخريف. أولا: دراسات اهتمت بالفن الشعبي: ا ـ دراسة: نورا السيد السيد الأثموني( درن (2013).

بعنوان: " إثراء التصميم الزخريِّ لملابس السيدات الخارجية بمزج التراث الشعبي المصري والخليجي".

هدفت هذه الدراسة إلى: مزج الزخارف الشعبية المصرية والزخارف الشعبية الخليجية معاً

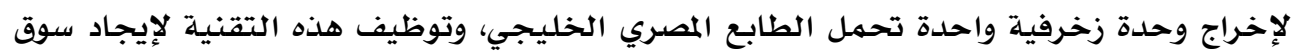

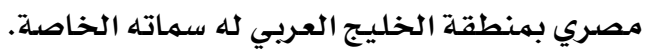




\section{وقد توصلت هذه الدراسة إلى مجموعة من النتائج من أهمها:إمكانية دمج الزخارف}

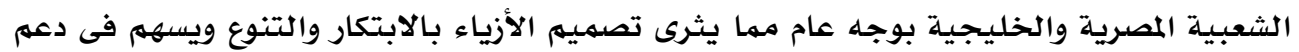

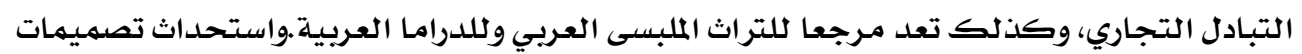

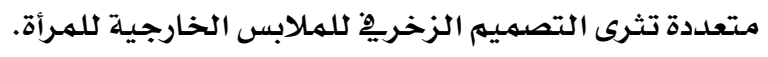
r. براسة نجوى كامل محمد بصيلة (2012).

بعنوان: " استحداث تصميمات مستوحاة من التراث الشعبي المصري والسعودي لإثراء

$$
\text { التصميم الزخربِ للملابس الخارجية للمرأة ". }
$$

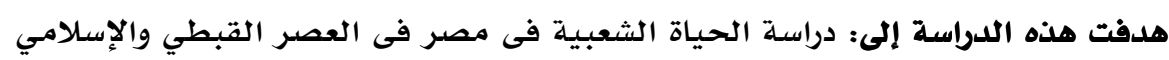

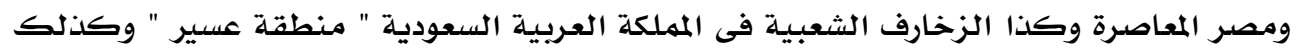

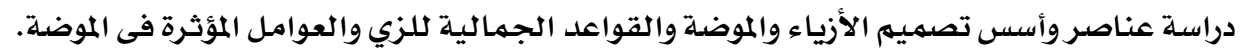
وقد توصلت الدراسة إلى مجموعة من النتائج أهمها:إمكانية الدمـج بين التراثين المصري

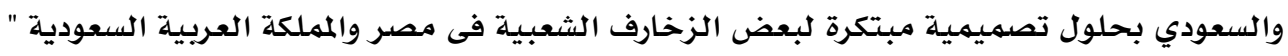

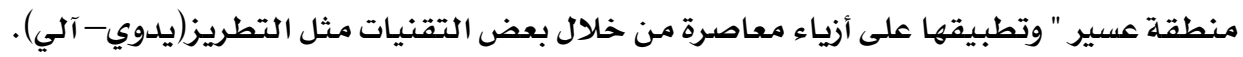

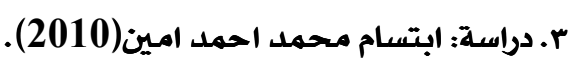
بعنوان: " دراسة أثر تغيير عناصر الوحدة الزخرفية الشعبين الشعبية المصرية على القيهم الجمالية

لأقمشة ملابس السيدات الصيفية المطبوعة".

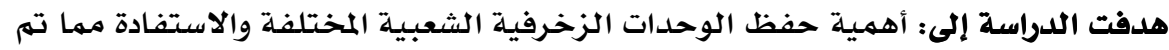

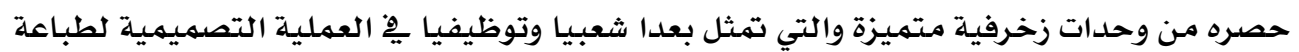

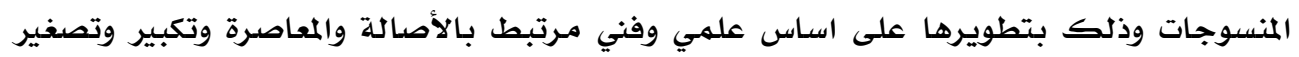

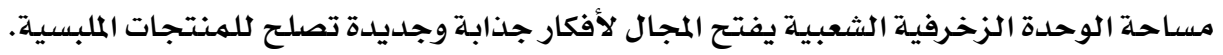

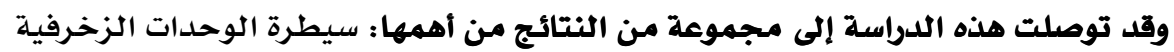

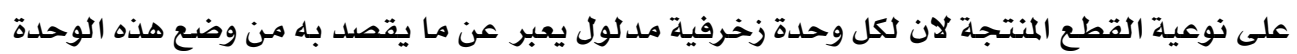

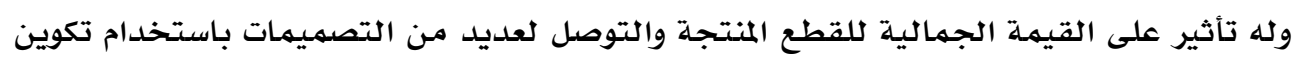

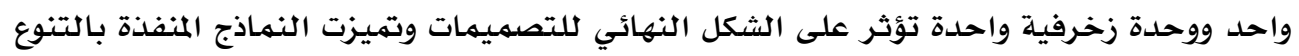

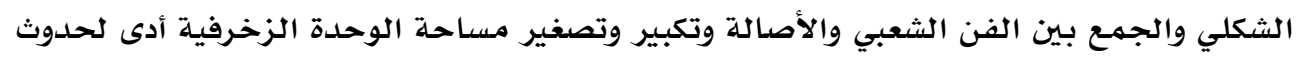

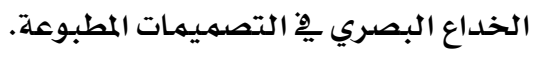
ع. دراسة: عبير إبراهيم عبد الحميد ومنى عزت حامد (2006).

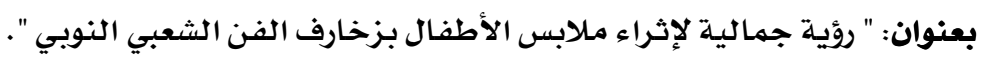
هدفت هذه الدراسة إلى: تحقيق أبعاد جمالية جديدة فى مجال ملابس الأطفال من خلاءل

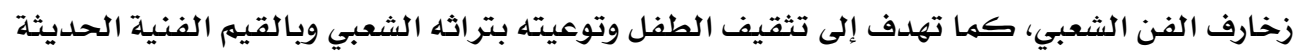

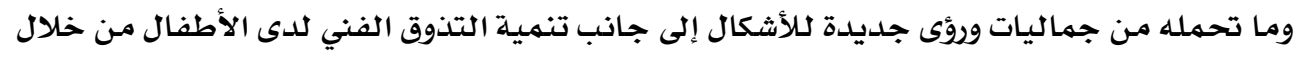

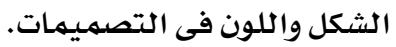


ب مجلة بحوث التربية النوعية - علدد

وقد توصلت هذه الدراسة إلى مجموعة من النتائج من أهمها: إمكانية تطويع الزخارف

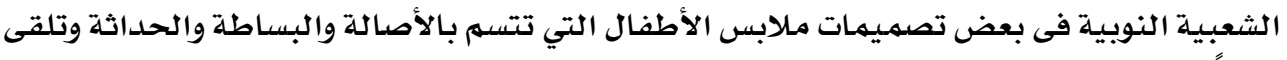

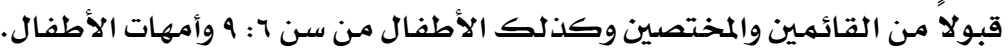
ثانيا: دراسات أهتمت بهلابس الأطفال: ا ـ دراسة: ألهام العزب السباعي بيومي(2015).

بعنوان: " الاستفادة من الحروف العربية يِّ اثراء ملابس الطفل وتثقيفه هِّ مرحلة مـا قبل المدرسة".

هدفت هذه الدراسة إلى: استخدام حروف الخط العربي يِ الحصول علي تصميمات ملبسية

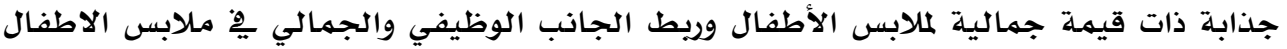

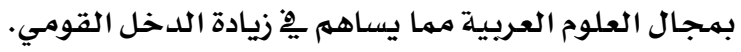
وقد توصلت هذه الدراسة إلى مجموعة من النتائج من أهمها: اضافة رؤية جديدة لمالابس

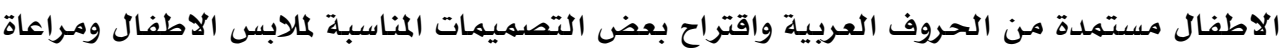

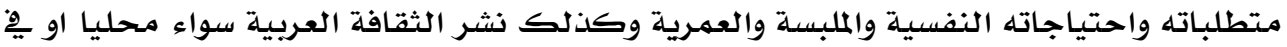
الاسواق الخارجية. r r دراسة أسماء فوزى محمد السيد(2013). بعنوان: " دراسة تحليلية تطبيقية لفنون الأطفال لاستحداث تصميمات جديدة لملابس الأطفال ومكملاتها". هدفت هذه الدراسة إلى: إلقاء الضوء على أهمية تصميهم ملابس للأطفال وأثرائها برسوم

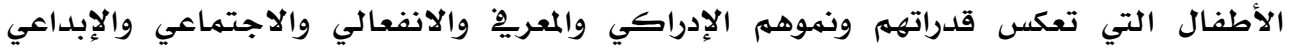

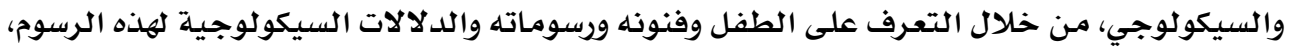

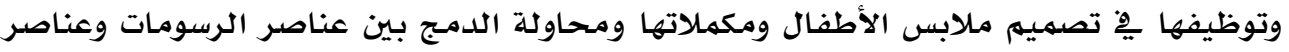

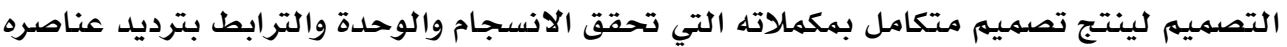

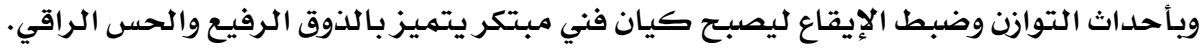

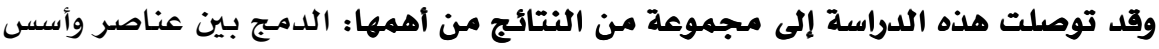

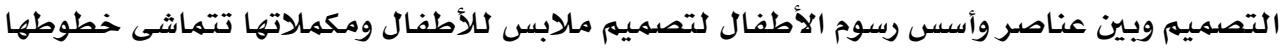

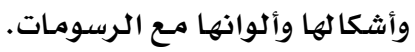
r. دراسة ثناء على رجب حجى (2012).

بعنوان:" إثراء التصميهم الزخريٌّ لزى الطفل المصري باستخدام برامج الحاسب الآلي ". هدفت هذه الدراسة إلى: تحديد سمات وخصائص رسوم الأطفال خلال المرحلة

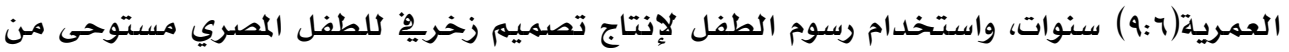

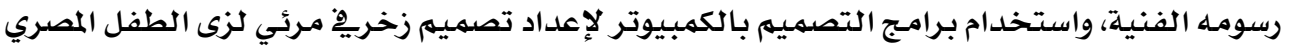




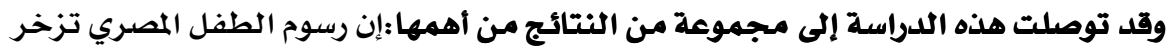

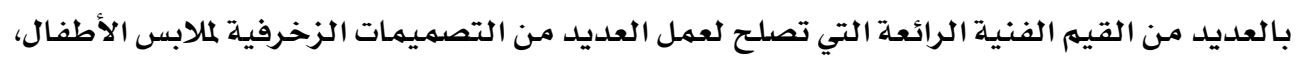

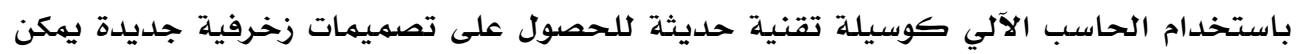

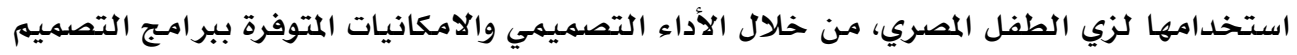

الآلية.

ع ـ دراسة: منى طارق حامد الجنايني( (2012).

بعنوان:" تصميمات زخرفية مبتكرة مستوحاة من الفن الإسلامي وأساليب تنفيذها على

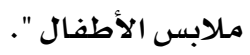

هدفت هذه الدراسة إلى:ابتكار تصميمات زخرفية جديدة تصلح لأزياء الأطفال فى مرحلة

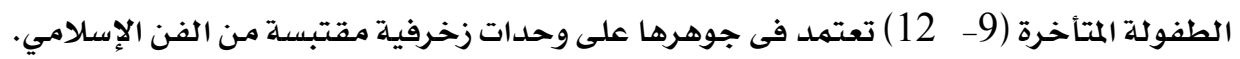

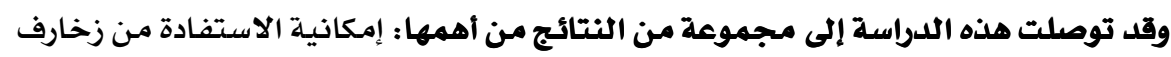

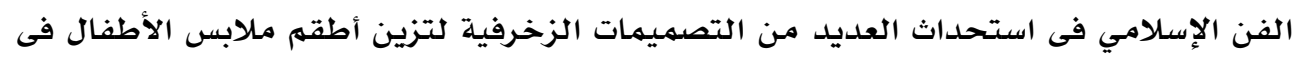

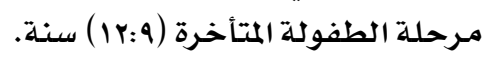
ثاثثا: دراسات أهتمت بالتصميم الزخرفي.

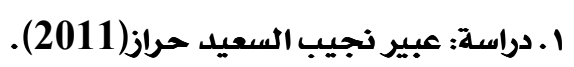

بعنوان: " إمكانية الاستفادة من بعض الزخارف الفرعونية يِّ استحداث تصميمات لإثراء الجانب الجمالي للمفروشات المنزلية".

هدفت هذه الدراسة إلى: دراسة عناصر الفن الفرعوني النباتية، الهندسية، والكتابية،

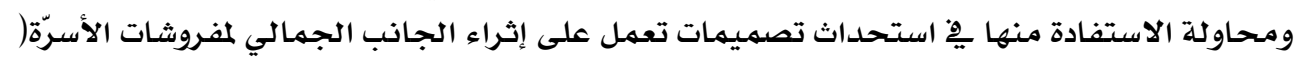
ملاءات ومفارث الأسرّة ) باستخدام بعض إمكانيات الحاسب الآلي برنامجج (Adobe Photoshop).

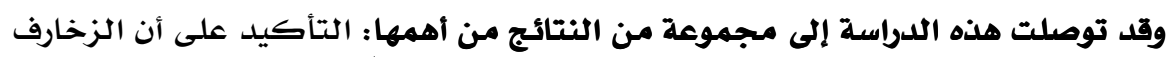

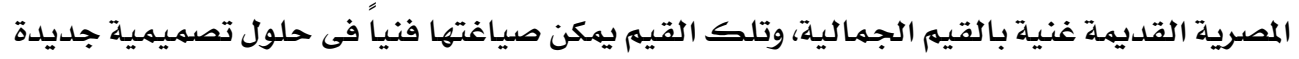

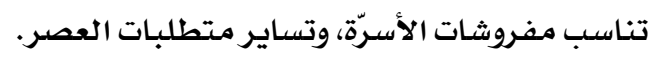
r. رنا محمد رضا محمد عيد فودة(2010).

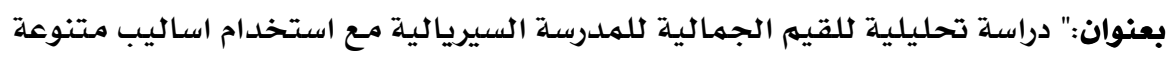
من التطريزوالطباعة لعمل تصميمات لتي شيرت الاطفال. هدفت هذه الدراسة إلى:الاستفادة من بعض التصميمات السيريالية واستخدامها لعمل

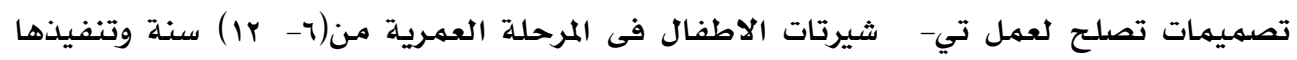

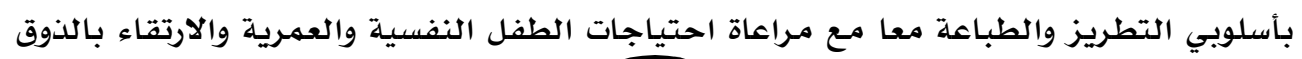


مجلة بحوث التربية النوعية - علدد

الملبسى ونشر الوعى الملبسى للطفل واستخدام الخامات الطبيعية فى تنفيذ تي- شيرتات الاطفال لتحقيق الراحة الوظيفيـة.

وقد توصلت هذه الدراسة إلى مجموعة من النتائج من أهمها: من خلال الدمـج بين الطباعة

والتطريز فى زخرفة مـلابس الاطفال يهكن الوصول الى الجودة الملبسيـة المطلوبـة وخاصسة مـع استخخدام الخامات الطبيعية التي تحقق الراحة الوظيفية للطفل. r. دراسـة: نجلاء محمد أحمد ماضي(2009) .

بعنوان:" ابتكار وحدات زخرفية مستمدة من العصر المملوكي والاستفادة منها ِِّ إثراء

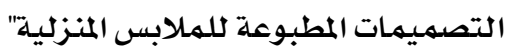

هدفت هذه الدراسة إلى: إلقاء الضوء على جماليات الفنون الإسلامية يِّ العصر المملوكي وكيفية معالجتها ببساطة، مها يؤكد الأصالة والمعاصرة وإمكانية استخدام عناصر العصر المملوكي بأسلوب فني تشكيلي يفي بالأغراض الجمالية والوظيفية ِِّ التصميهم الطباعي الزخريخ للمهلابس المنزلية. وقد توصلت هذه الدراسة إلى مجموعة من النتائج من أهمها: استخدام اسلوب الطباعة بالنقل الحراري يِّنفيذ الملابس المنزليـة. ع. دراسة: صفاء صبري إبراهيم الصعيدي(2007). بعنوان :"الإفادة من الزخارف الفرعونية يخ تصميهم وتطريز بعض القطع الملبسية لدعم

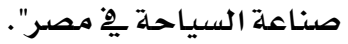

هدفت هذه الدراسة إلى:دراسـة زخارف التراث المصري القديه وكيفية تطويعها لعمل تصميمات مبتكرة تصلح للتطريز وتساهم فِ تسويق المنتج السياحي، مها يشجـع على قيام صناعات صغيرة تساهم مِ حل مشكلة البطالة. وقد توصلت هذه الدراسة إلى مجموعة من النتائج من أهمها : نجاح أسلوب التطريز اليدوي يتوقف على الاختيار الأمثل للتركيب النسجي كلأقمشة الحلديثة كما يتوقف على طبيعة الوحدة الزخرفية والأيدي المدريسة والواعية لأبعاد التصميهم والتنفيذ لكى تصلح يخ عمل تصميمات زخرفية مطرزة على قطع ملبسيـة تسـاهم مِّن تنوع المنتج السياحي.

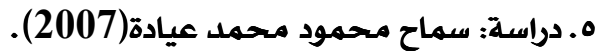

بعنوان: "الاستفادة من التطريز يِّ دعم وإثراء الصناعات الصغيرة بهـحافظة المنوفيـة". هدفت هذه الدراسة إلي: توضيح أهميـة التطريز بأسلوبين (الآلي واليدوي) يِّ مـجال صناعة الملابس الجاهزة، أدى إلى خفض تكلفة عينـة التطريز مـ إعطائها شكل جمالي أفضل وذلك من خلال تطبيق أسلوب التطريز الجديد. وقد توصلت هذه الدراسـة إلى مجموعة من النتائج من أهمها: إضافة التطريز الجديد حقق شكل جمالي أفضل على الملابس والمكمالات، وكذلك خفض تكلفة العينة المطرزة على الملابس والمكماتلات. 
بعنوان "إمكانية الاستفادة من مهارات التصميم والتطريز والكروثيه لطلاب الاقتصاد الكام المنززي".

هدفت هذه الدراسة إلى: تقديم مجموعة من المنتجات الملبسية المبتكرة والمزينـة باستخدام

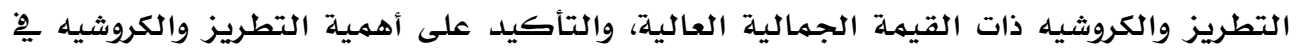

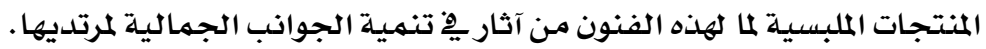

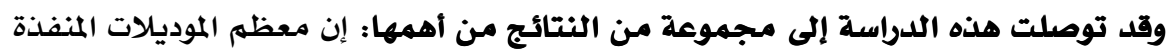

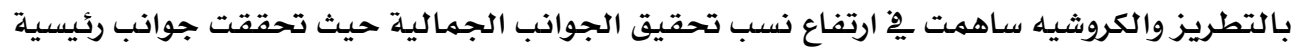

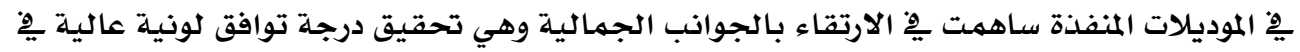

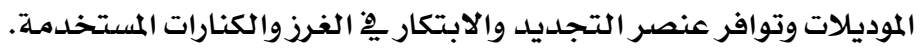
V V دراسة صافيناز سمير محمد (2003).

بعنـوان: " اسـتحداث وحسدات زخرفيـة معاصـرة وتطبيقهـا بأسـاليب التطريـز والطبـاعـة معـا لإثراء جماليات ملابس الطفل ".

هدفت هذه الدراسة إلى:تحقيق قيم جمالية فنية تشكيلية عن طريق استحداث تصميمات

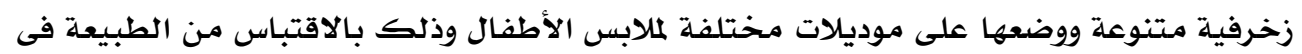

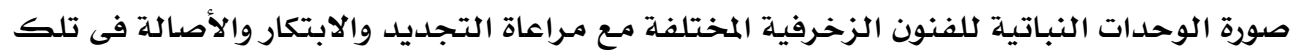
التصميمات المستحدثة. وقد توصلت الدراسة إلى مجموعة من النتائج من أهمها: هناك دلالة إحصائية بين درجة

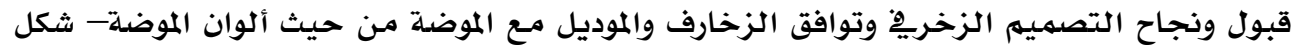

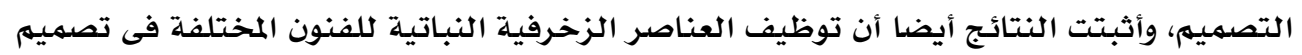

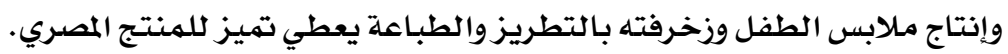

الدراسة النظرية الأساليب المستخدمة في إثراء التصميم الزخرفي: تعتبر الزخرفة من أهم الفنون التشكيلية وأعظمها اثرا ِِّ إكساب معظم المنتجات

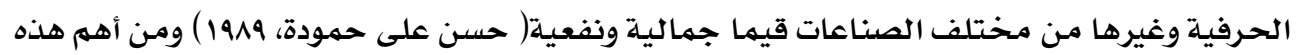

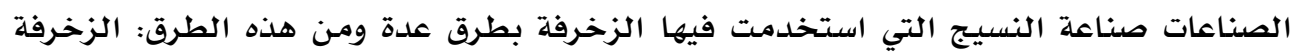

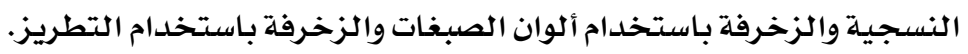
طرق إحداث الزخرفة:

\section{الزخرفة النسجية: Decoration Of Textile}

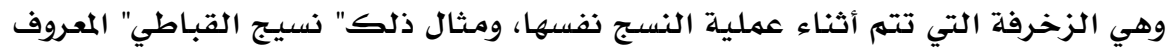

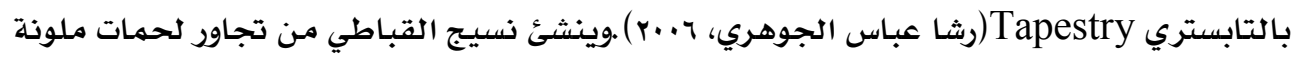


مجلة بحوث التربية النوعية - علدد VI - بوليو P.lV

تنسج بطريقة غير ممتدة ِِّ عرض المنسوج أحدهما تمثل الأرضية واللحمات الأخرى تمثل الزخرفة

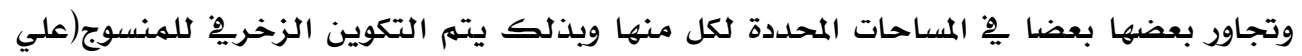

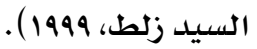

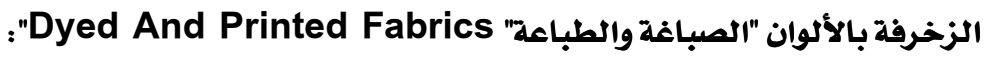

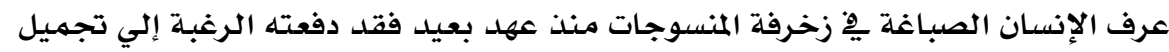

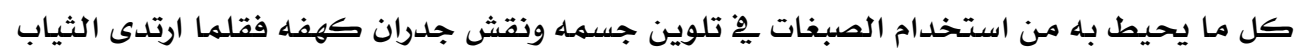

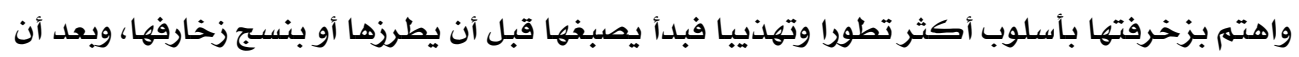

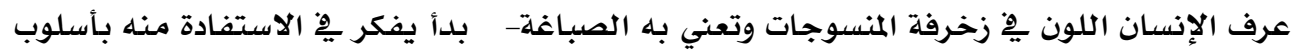
زخريف.

يستطيع عن طريقه تسجيل بعض المظاهر الطبيعية التي تحيط بـه فاخترع طباعة

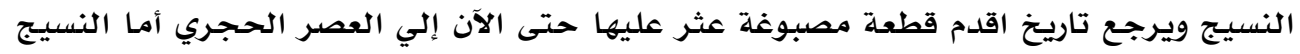

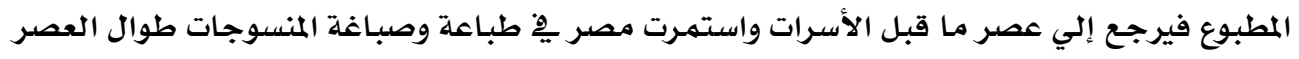

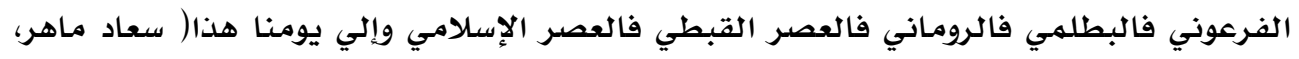

(1979

\section{الزخرفة بالتطريز (19)، : Embroidery:}

التطريز أساسا هو زخرفة المنسوجات بعد أن يتم نسجها وقد تتم عملية التطريز بواسطة

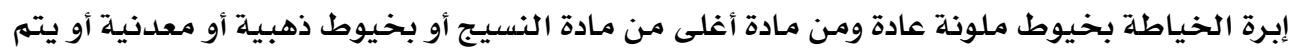

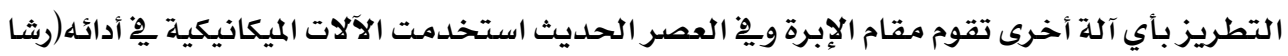

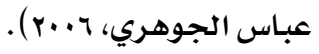

التقنيات المبتفدهة في البرزء التطبيقي:

أولا التطريز::

غرز التطريز:

تعريف الغرزة:

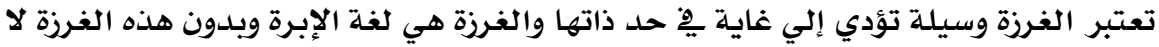

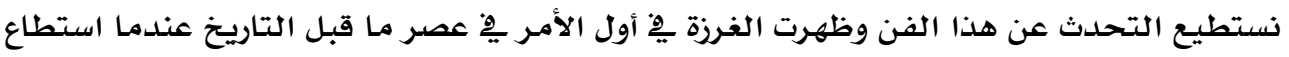

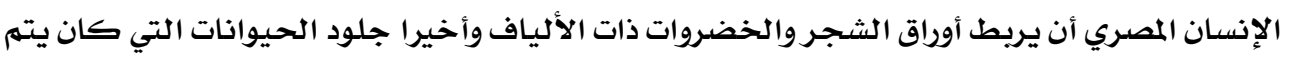

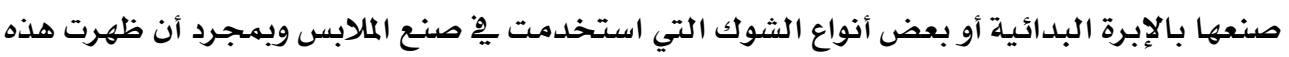

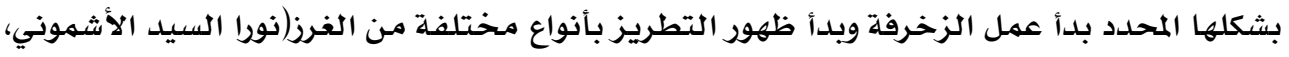
. r. r r r 
يتضمن التطريز اليدوي العديد من الغرز التي تستخدم بأساليب مختلفة وبهمهارة عالية

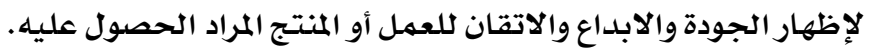

ويمكن تقسيمها كالاتي كما يِ المخطط (1) الذي يوضح انواع غرز التطريز اليدوي.

مخطط (1) يوضح انواع غرز التطريز اليدوي(صافيناز سمير محمد، ب...r)
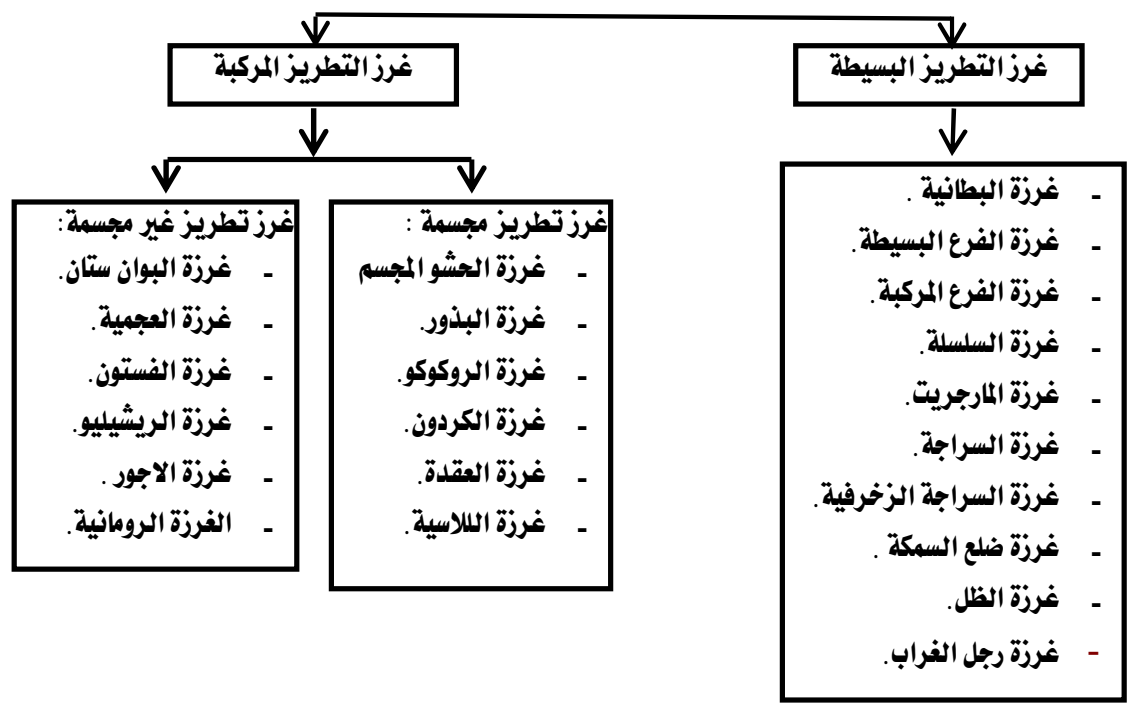

غرز التطريز المستخدمة بالبحث:

تستند الدراسة إلي استخدام بعض غرز التطريز اليدوي بما يتناسب مـع المنتج المنفذ، وفيما

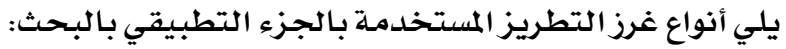

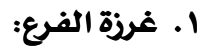

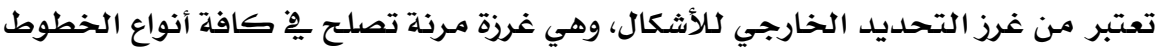

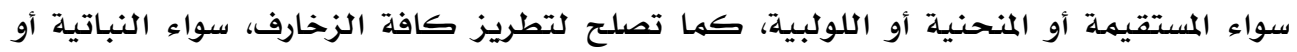

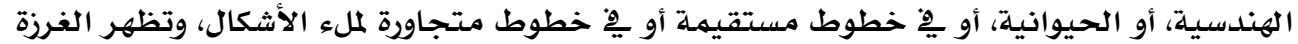

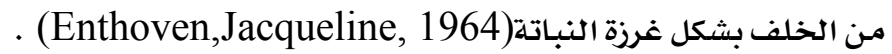

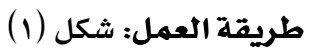

$$
\text { ا ـ يثبت طرف الخيط من الجهة اليسرى. }
$$

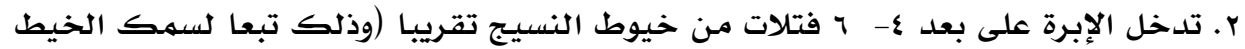

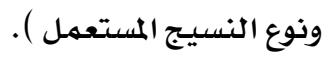


r. تخرج الإبرة من منتصف المسافة وهذا بالنسبة للغرزة الأولى فقط.

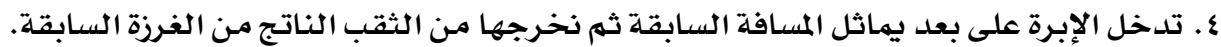

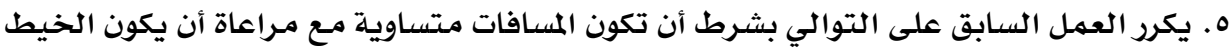
مِّ2 اتجاه واحد) (John, Edith, 1973).

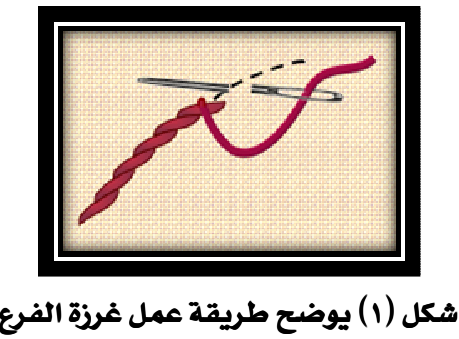

(https://crafty4all.com/archives/5308 28/1/2107 1:38Bm)

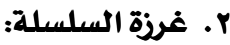

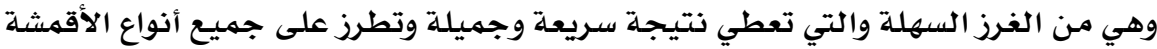

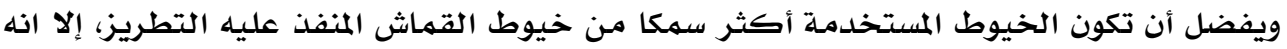

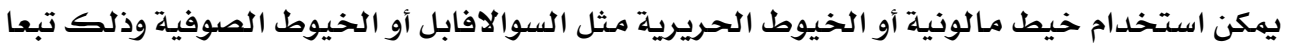

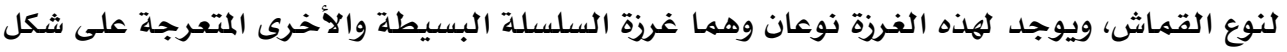

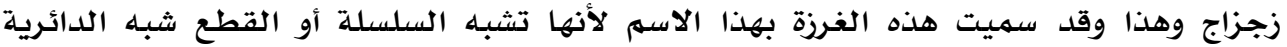

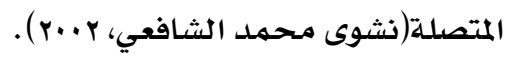

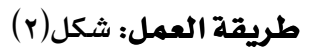

ا.تبدأ الغرزة من اليسار إلي اليمـين بتثبيتها يْ ظهر القماش ثم تخرج عند أول الخط المراد

$$
\text { تطريزه. }
$$

r. من نفس النقطة وعلى بعد ع فتلات تقريبا تبدأ أول غرزة ويكون الخيط أسفل الإبرة ثم تجذب

$$
\text { الإبرة. }
$$

r.مِّ الغرزة التالية توضع الإبرة دائما عند النقطة التي خرجت منها آخر غرزة كل مـرة، وإذا

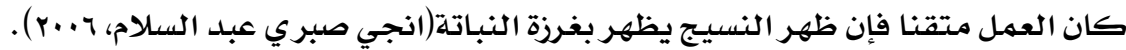

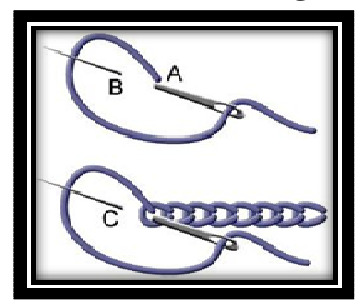

شكل (r) يوضح طريقة عمل غرزة السلسلة

(https://www.pinterest.com/pin/47491872319147844628/1/20171:55) 
تطرز بهذه الغرزة رسم وردة المارجريت وهي طريقة سهلة وتعطي نتيجة سريعة وجميلة

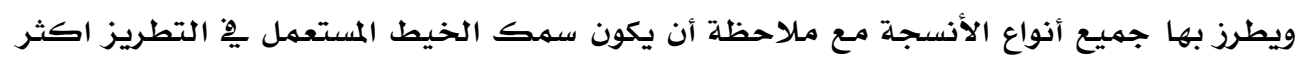

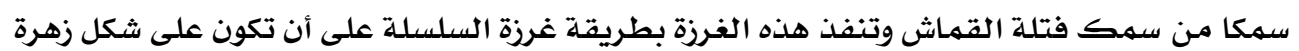

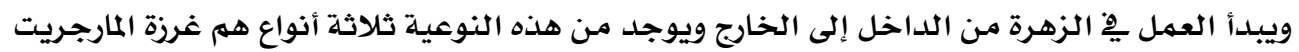

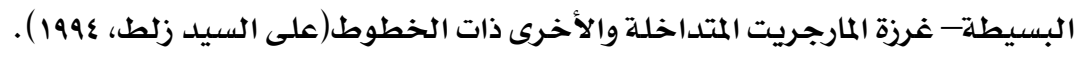
طريقة العمل: شكل(r) البطيطة ا . بعد تثبيت الخيط خلف القماش عند إحدى وريقات الوردة من الداخل تخرج الإبرة مكان

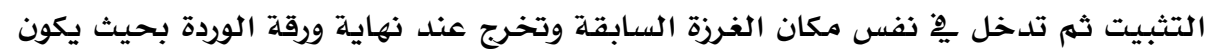

$$
\text { الخيط تحت الإبرة. }
$$

r. يشد الخيط برفق حتى لا تقفل الغرزة ثم تدخل إلي الإبرة الخلف خارج الغرزة المتكونة

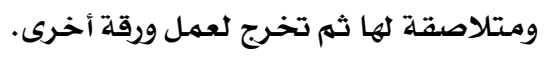

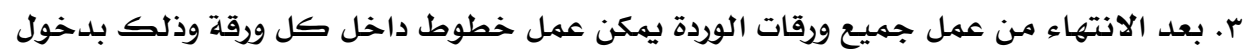

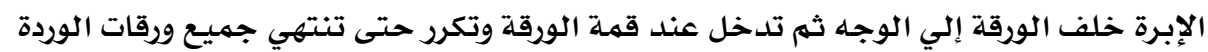

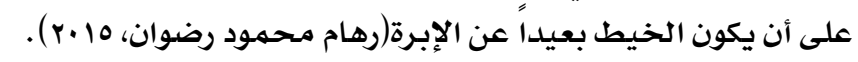

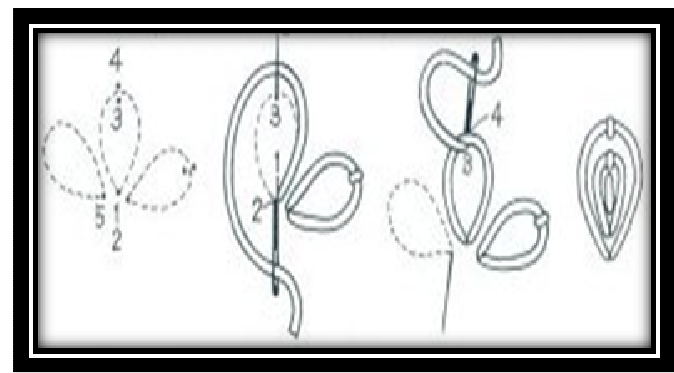

$$
\text { شكل (r) يوضح طريقة عمل غرزة المارجريت }
$$

1:57)http://legrenierdebibiane.com/Broderie/point_de_bouclette.html 28/1/2017 (

$$
\text { ع. غرزة الروكوكو: }
$$

عبارة عن مجموعة من اللفات التي تعطي خط حلزوني على القماث وتعطي شكلاً رقيقاً

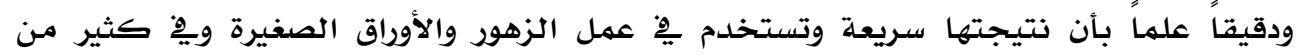

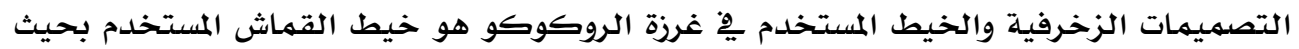

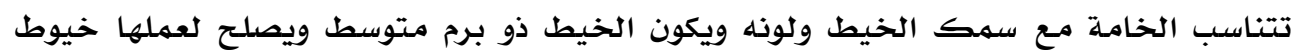

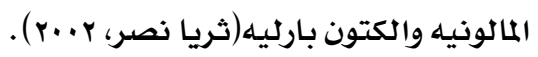


ا. يتم تثبيت الخيط ِِّ النسيج، ثم يأخذ مسافة من أرضية النسيج تحدد هذه المسافة حسب

$$
\text { طول الغرزة المطلوبة وارتفاعها. }
$$

r. يتم لف الخيط حول الإبرة عدد من اللفات بحيث تغطي هذه اللفات المسافة المأخوذة من أرضية

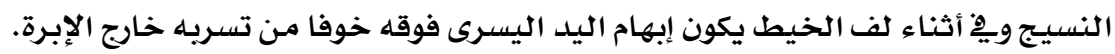

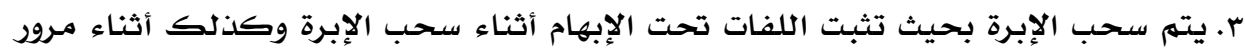

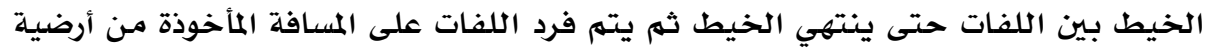

النسيـج.

ع. وبعد ذلك تثبت الغرزة، وتكرر هذه الطريقة يِّ المساحة المطلوبة(word ,Lock, 1962).

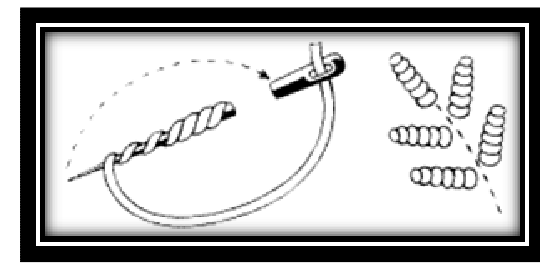

شكل (๕) يوضح طريقة عمل غرزة الروكوكو

(https://forum.hawahome.com/t190207.html 28/1/20171:50)

0. غرزة السراجة: شكل(0)

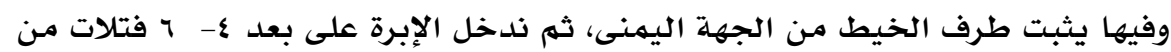

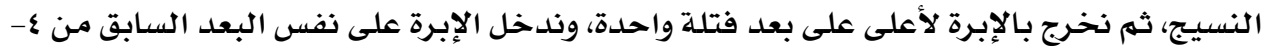

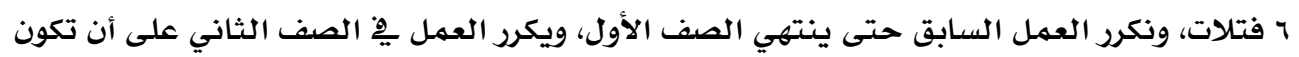

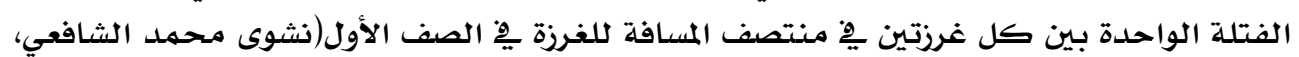
. ( r... r

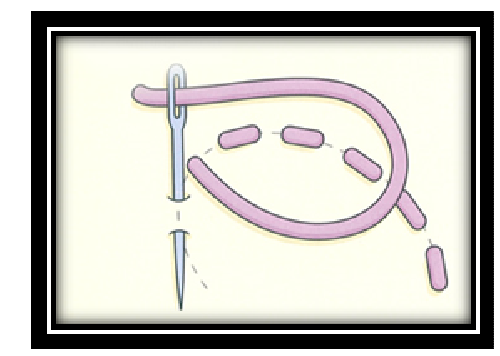

$$
\text { شكل (0) يوضح طريقة عمل غرزة السراجة }
$$

(https://crafty4all.com/archives/5308 at 28/1/2017 2;00) 
تستخدم هذه الغرزة يِّ إنهاء أطراف القماث غير قابل للتنسيل أو لتثبيت القماش المضاف

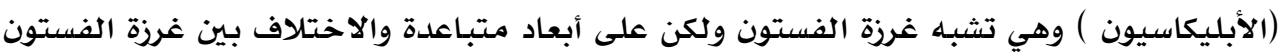

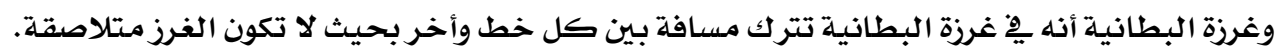

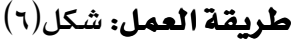

ا ـ يثبت الخيط ِِّ طرف القماش ويوضـع الخيط تحت إبهام اليد اليسرى ونبدأ من جهة اليسار.

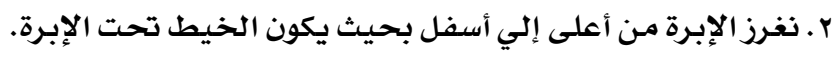

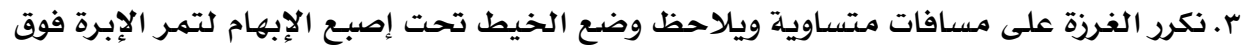

$$
\text { الخيط(علا على علوان، ..... بـ). }
$$

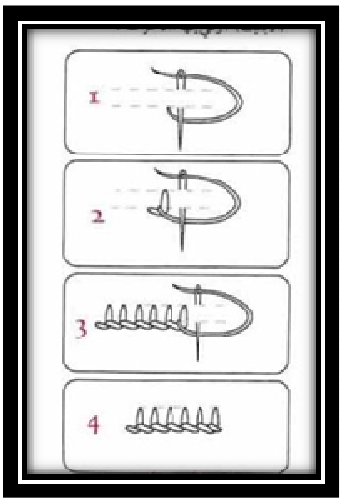

$$
\text { شكل (7) يوضح طريقة عمل غرزة البطانية }
$$

(http://www.bntmofeid.com/vb/showthread.php?t=17144 at 28/1/2017 2:09)

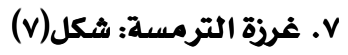

هي نفس غرزة البطانية مـع عدم ترك مسافات ويفضل دائما عمل غرزة شلاله قبل غرزة

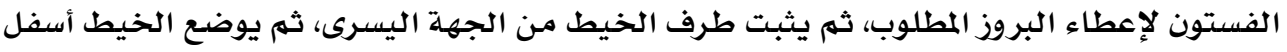

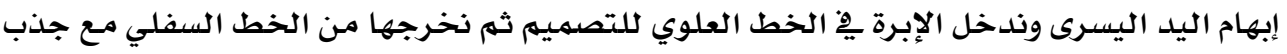

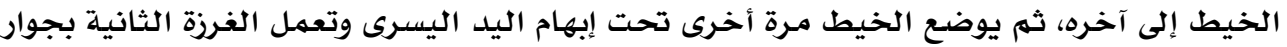

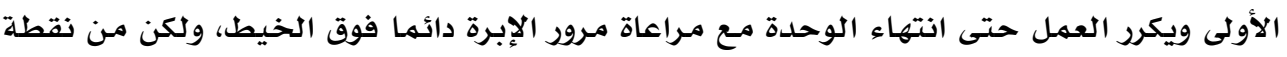

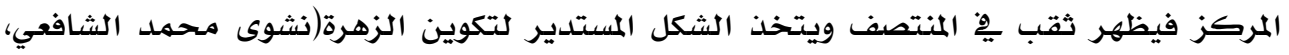




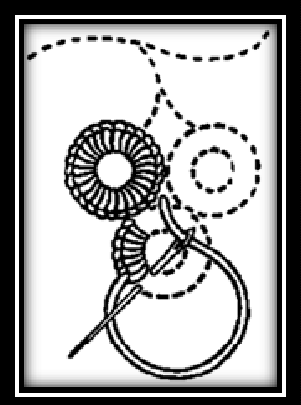

ثكل (v) يوضع طريقة عمل غرزة الترمسة

(http://www.bntmofeid.com/vb/showthread.php?t=17144 at 28/1/2017 2:07)

1. غرزة ضلع السمكة:

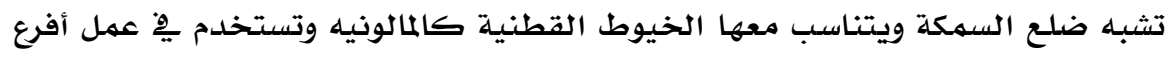

الشجر وبعض التصهيمات الأخرى ويناسبها خيط المالونيه وهي من الغرز السهلة السريعـة التنفيذ

والجميلة الشكل ويطلق عليها اسهم الغرزة المرجانية وتستخدم عادة يْ ملء الأثرطة والكنارات

وكذلك يخ تطريز أوراق الشجر والزهور وسميت بهذا الاسهم نظرا لتشابهها بضلع السهكة.

طريقة العمل: شكل(ی)

$$
\text { ا . يثبت طرف الخيط جهة اليسار. }
$$

r . تغرز الإبرة مـائلة متتجهة إلى أسفل من جهة اليسـار إلى جهة اليهـين.

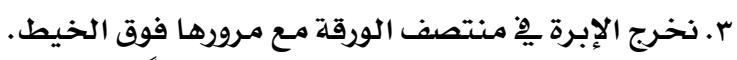

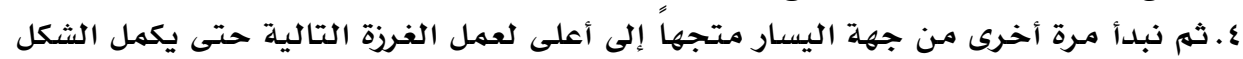

$$
\text { المطلوب تطريزه(صفاء صبري الصعيدي، V... r). }
$$
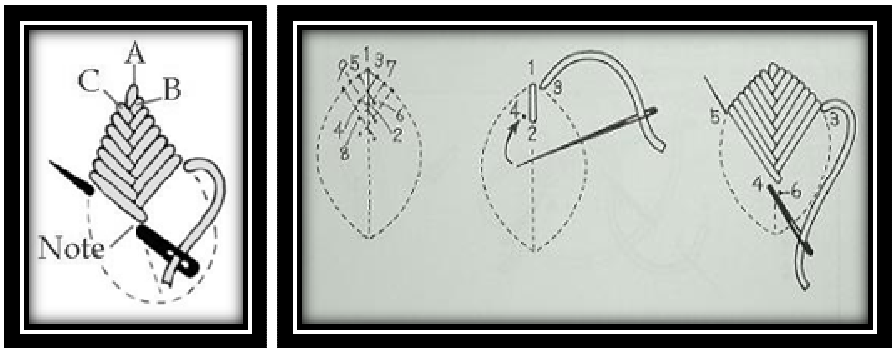

$$
\text { شكل (ی) يوضتح طريقة عمل غرزة ضلع السمكة }
$$

( http://www.iza-broderie.com/pages/les-principaux-points-de-broderie at 28/1/20171:45)

$$
\text { 9. غرزة الحشو: }
$$

تطرز بها المفارث وفساتين الأطفال وقمصان النوم والبلوزات وأي رسم مكون من خطين

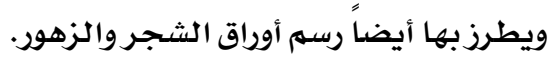


طريقة العمل: شكل(q)

تعمل سراجات صغيرة( غرزة السراجة) تحدد شكل الرسهم ثم تشغل بغرزة الحشو وذلك الكا

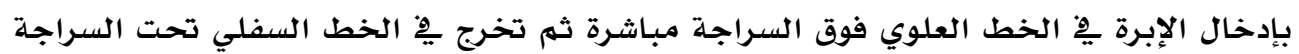

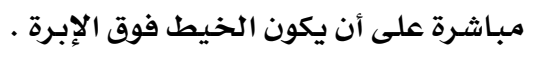

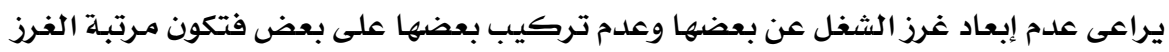

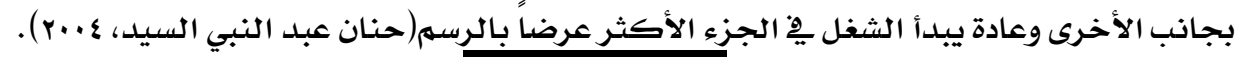

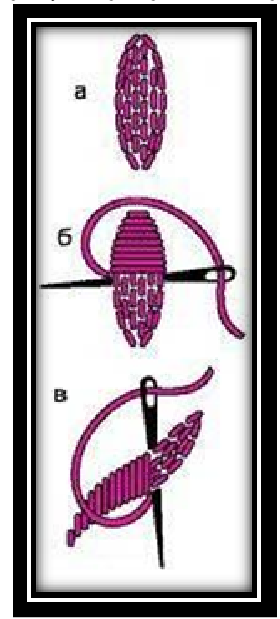

شكل (9) يوضح طريقة عمل غرزة الحشو

(http://ito.vspu.net/ENK/TIMTPN/webquest_2011/Bilohvostukova_Melnuk_Frasuny k/t.2.1.hm at 28/1/2017 10:56)

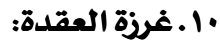

يطلق عليها (غرزة الللاسية ) وهي عبارة عن وحدات صغيرة متكررة وكل وحدة تتكون من

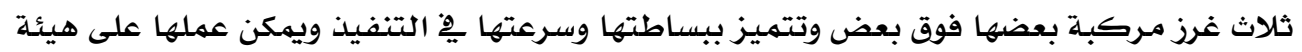

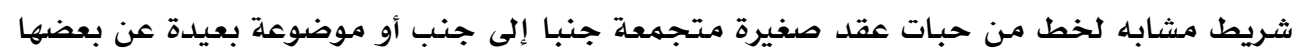

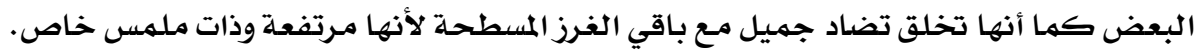
طريقة العمل: شكل( 1. 1 )

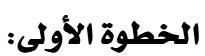

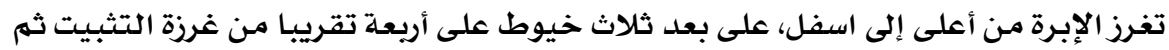

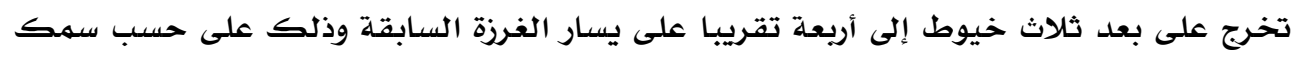
الخيط ونوع النسيج، بحيث يتوسطها خط الزخرفة، فتنتج غرزة مائلة إلى أعلى نوعا.

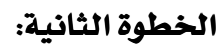

ثم تدخل الإبرة من أعلى إلى اسفل تحت الغرزة السابقة بحيث لا تخترق النسيج. 


\section{الخطوة الثانثة:}

تدخل الإبرة ثم تخرج مارة تحت الغرزة الأولى على أن يكون الخيط أسفلها بحيث لا تخترق

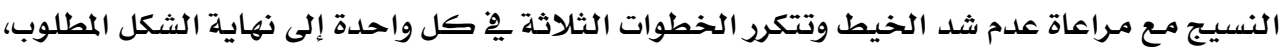

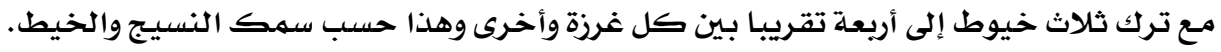

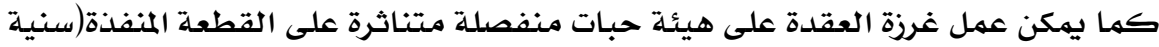

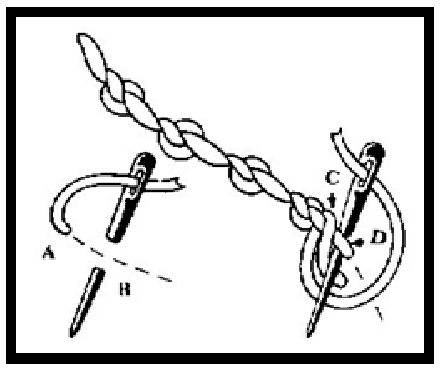

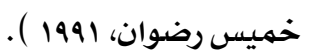

\section{شكل ( م ) يوضح طريقة عمل غرزة العقدة}

(http://www.stooob.com/646247.html at28/1/2017 2: 10.)

(11 ا.غرزة بخارة (الحصيرة ):

وتسمى هذه الغرزة باسهم الغرزة البارزة وهي سريعة وسهلة التنفيذ وتستخدم لملء المساحات

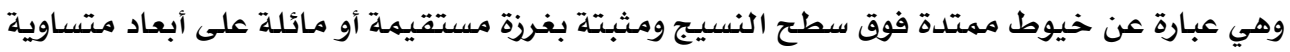

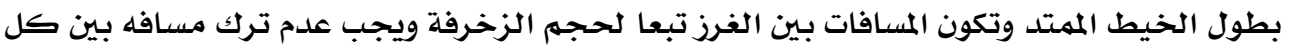
خيط وآخر واستخدام الخيوط السميكة مثل الخيط(الكتون بارليه ) ليساعد على بروزها بطريقة

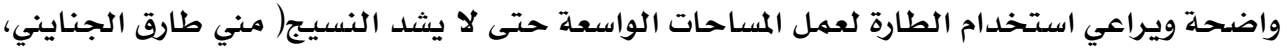

طريقة العمل: شكل(11) (11)

ا ـ يثبت طرف الخيط من جهة اليسار.

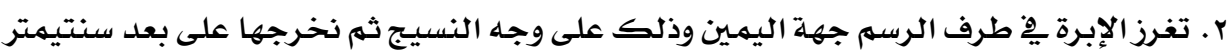

$$
\begin{aligned}
& \text { تقريبا وذلك تبعا لحجم الزخرفة وسمك الخيط ونوع النسيج المستخدم. } \\
& \text { r. تخرج الإبرة من تحت الخيط لنحصل على سطر أفقي من الخيط. }
\end{aligned}
$$

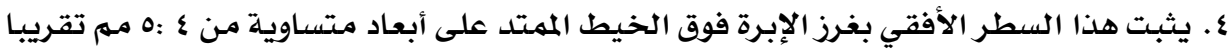

$$
\text { ويكرر التثبيت إلى آخر الخيط الأفقي المثمتد. }
$$

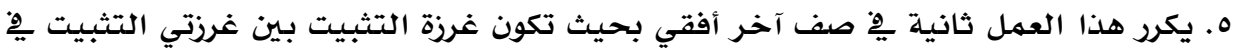
السطر السابق حتى يهتلئ فراغ الرسم المراد تطريزه ويراعى عند عمل فرئ فرزة بخارة أن يكون 


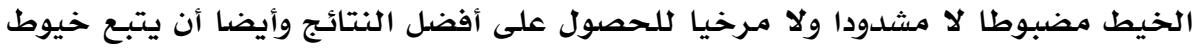

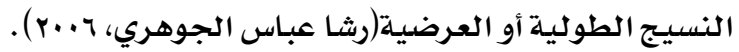

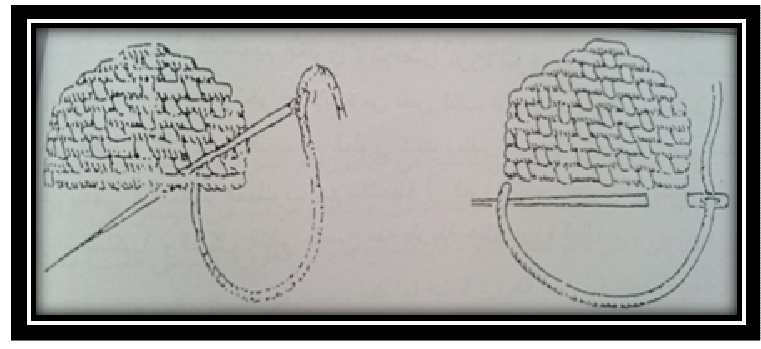

شكل (11) يوضح طريقة عمل غرزة بخارة (رشا عباس الجوهري، ج ..r).

r ا ـ أسلوب النسيج المضاف( الأبليك): ويقصد به الزخرفة بقماش مخالف للقماث المراد تطريزه أو من نفس القماث وكثيراً ما

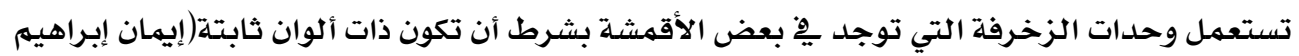

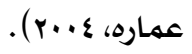
طرق حياكة النسيج سابق التجهيز ( الأبليك) اليدوي:

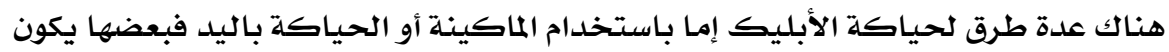

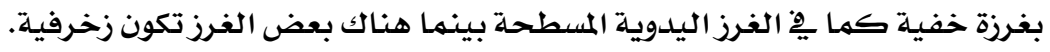

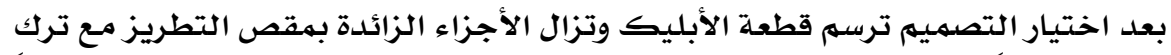

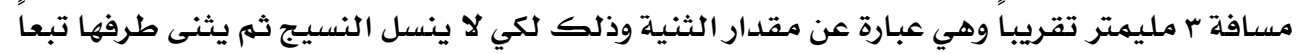
للرسهم. مِّْ حالة استخدام الأقمشة الغير قابلة للتنسيل يتم قصها على حدود الرسهم(رشا عباس

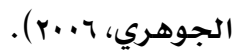
عند الحياكة باليد لابد من استخدام إبرة حادة و خيط قطني جيد ويهكن أن يكون لون

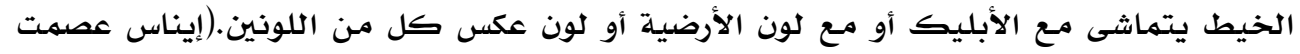

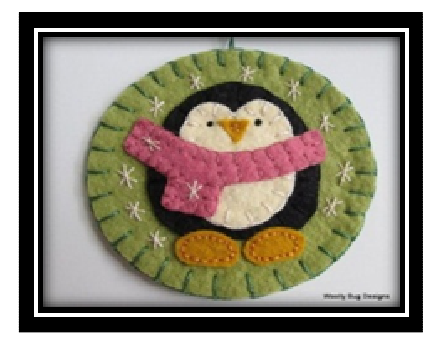

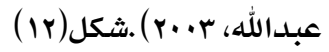

$$
\text { شكل(r) يوضـح شكل الأبليك }
$$

(https://www.pinterest.com/pin/367324913329083353/28/1/201710:30) 


\section{ثانيًا: أسلوب الطباءة:}

يطلق مصطلح طباعة المنسوجات على العمليات التي تجرى على الخامـات النسجية بقصد

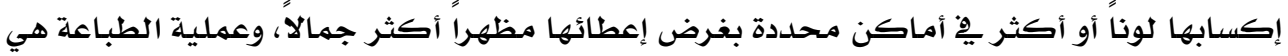

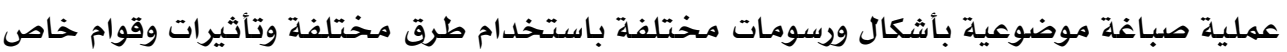

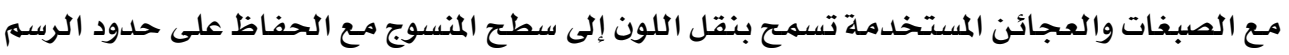

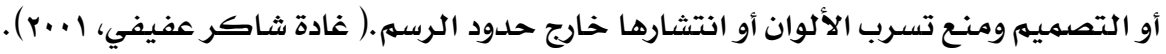
الطرق المختلفة للطباعة اليدوية على المنسوجات:

تتلخص طرق الطباعة اليدوية يِّ الآتي:

$$
\begin{aligned}
& \text { 1. الطباعة بالقوالب الخشبية. }
\end{aligned}
$$

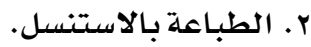

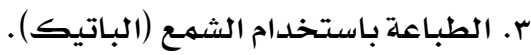

$$
\begin{aligned}
& \text { ع. الطباعة باستخدام الشابلونات. }
\end{aligned}
$$

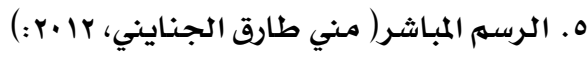

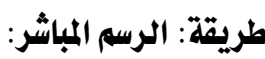

وسوف يتم استخدام أسلوب الرسم المباشر ِِّ الجانب التطبيقي لذا سوف يتم التعريف بهذا الأسلوب.

تعد طريقة الرسم المباشر على الأقمشة من الطرق التي يكون لها إمكانات كثيرة يستطيع

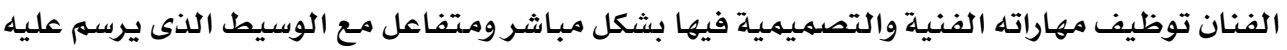

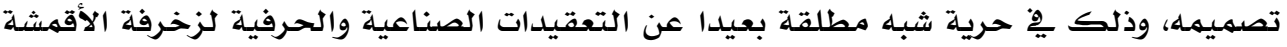

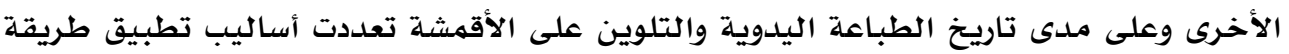

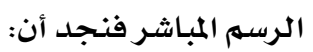

استخدمت هذه الطريقة" الرسم المباشر" يِّ بعض قطع المنسوجات الإيرانية المطبوعة

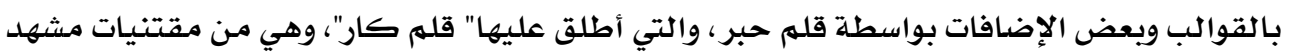
الإمام على بالنجف بالعراق. استخدم" القلم البسط" يِّ رسم الزخارف على بعض المنسوجات التي يرجـع تاريخها للعصر

$$
\text { المملوكي. }
$$

استخدمت طريقة الرسم المباشر أيضا ِِّ إبراز الإحساس بالظلال وإضفاء التدخلات

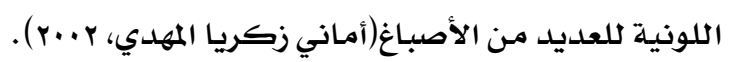

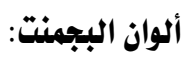

تستخدم هذه المجموعة من الملونات يْ طباعة وصباغة الأقمشة عن طريق تحضير محاليل

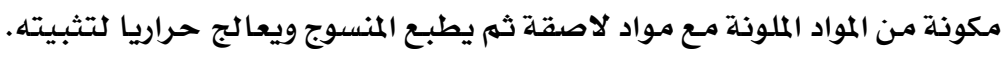




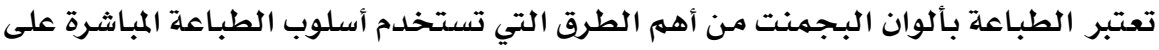

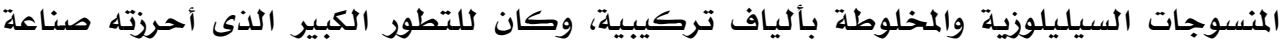

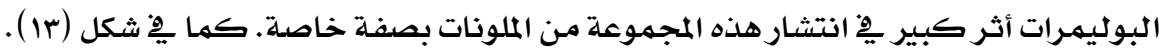

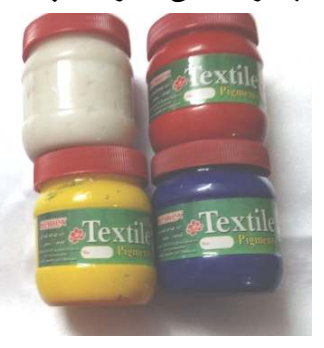

شكل(r) يوضح ألوان البجمنت(من تصوير الباحثة)

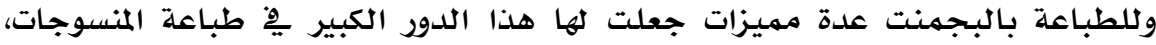

وكذلك التشكيل الفني لمنسوجات المعلقات بصفة خاصة منهات منها:

ا. سهولة طباعة المنسوجات السيليلوزيـة والمخلوطة، حيث لا تتطلب عمليات تكميلية كثيرة

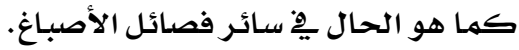

r. يمكن استخدامها بدون مشاكل تقنية معقدة مِّ طباعة الألياف الصناعية والمخلوطة، والتي

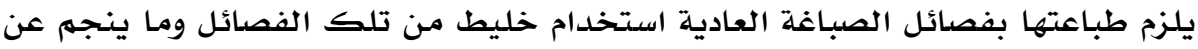

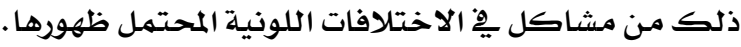

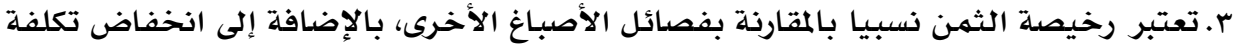

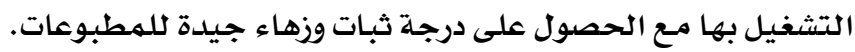

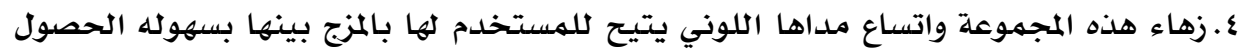

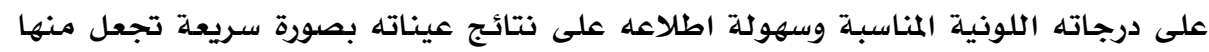

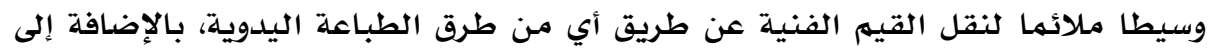

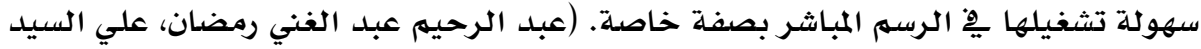

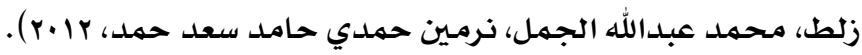

ألواز أكريليك:

هي ألوان صناعية بلاستيكية سريعة الجفاف وتحتفظ برونقها بعد جفافها ولا تسيل

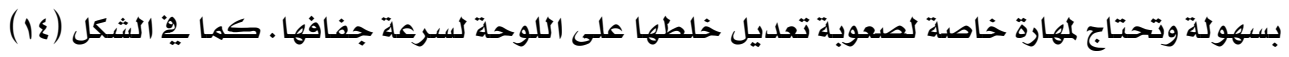

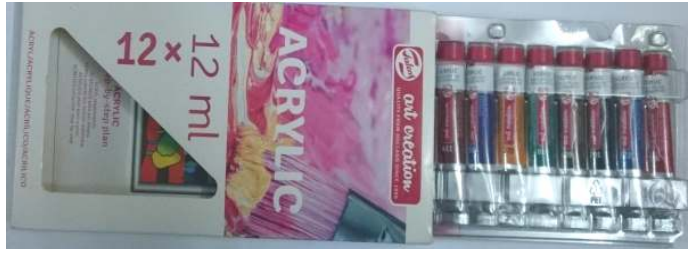

شكل(£ ) يوضح ألوان الاكريليك (من تصوير الباحثة). 


\section{مميزات ألوان الاكريليك:}

ا ـ الألوان واضحة وبراقة تدوم وقتا طويلا.

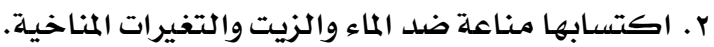

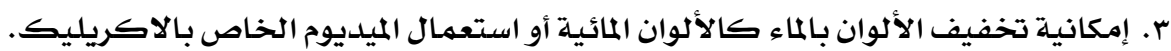
ع. إمكانية استعمال ألوان الاكريليك على أنواع كثيرة من السطوح التي تمتص الألوان.

(http://www.qassimy.com/vb/showthread.php?t=233739 at 18/1/201711:04AM)

\section{النتائج والمناقشية:}

أولا: تتائج استمارة تقيييم ملابس الطفل المنفذة باستخدام تصميمات من الفز الشعبي في ضوء آراء المحكمين. الفرض الأول: توجد فروق ذات دلالة إحصائية بين الموديلات المنفذة بِ تحقيق الناحية الوظيفية وفقا

$$
\text { لآراء المحكمين". }
$$

وللتحقق من هذا الفرض تم حساب تحليل التباين لمتوسط درجات الموديلات المنفذة ِِِ

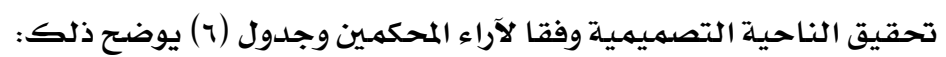

جدول(7) : تحليل التباين لمتوسط درجات الموديلات المنفذة يخ تحقيق الناحية الوظيفية وفقا لآراء المحكمين.

\begin{tabular}{|c|c|c|c|c|c|}
\hline الدلالة & قيمة "ف" & متوسط المربعات & درجة الحرية & مجموع المربعات & الناحية الوظيفية \\
\hline \multirow[t]{3}{*}{.380} & \multirow[t]{3}{*}{1.089} & 5.829 & 4 & 23.314 & بين المجموعات \\
\hline & & 5.352 & 30 & 160.571 & داخل المجموعات \\
\hline & & & 34 & 183.886 & المجموع \\
\hline
\end{tabular}

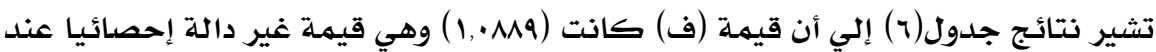

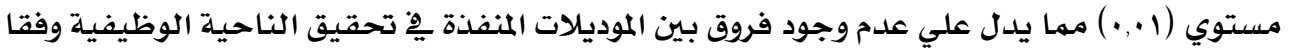

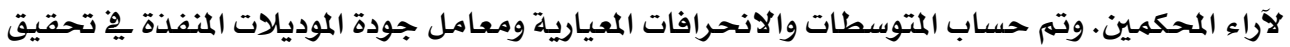

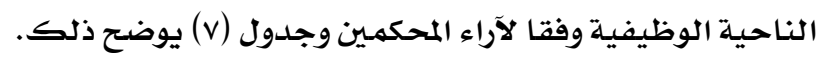

جدول(v): المتوسطات والانحرافات المعيارية ومعامل الجودة لدرجات الموديلات المنفذة يُ تحقيق الناحية الوظيفية وفقا لآراء المحكمين.

\begin{tabular}{|c|c|c|c|c|}
\hline الترتيب & معامل الجودة & الانحراف المعياري & المتوسط & الموديل \\
\hline 3 & 94.92 & 2.87 & 42.71 & الموديل 1 \\
\hline 4 & 93.02 & 2.54 & 41.86 & الموديل r \\
\hline 5 & 91.11 & 2.83 & 41.00 & الموديل r \\
\hline 2 & 95.24 & 1.57 & 42.86 & الموديل ؛ \\
\hline 1 & 96.19 & 1.25 & 43.29 & الموديل ه \\
\hline
\end{tabular}




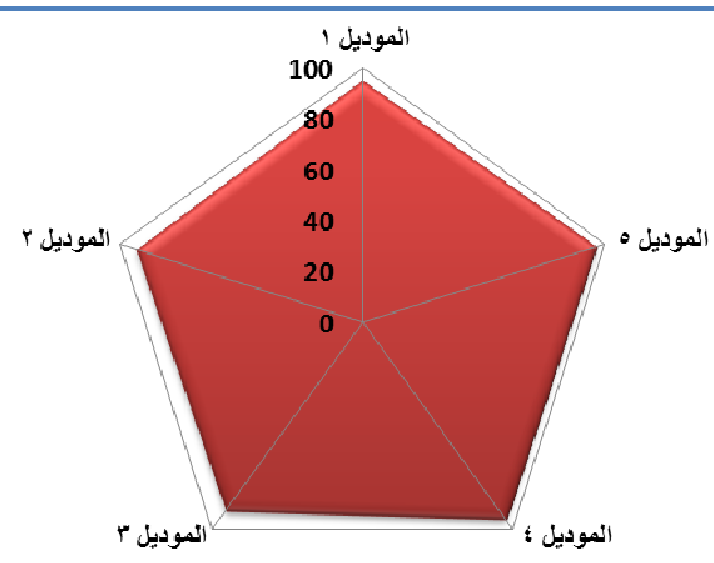

شكل (10) يوضح معامل الجودة لدرجات الموديلات المنفذة فِ تحقيق الناحية الوظيفية وفقا لآراء المحكمين.

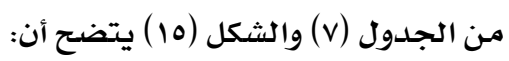

فنجد أن أفضل الموديلات المنفذة يِّ تحقيق الناحية الوظيفية، وفقا لآراء المحكمين الموديل

(ه)، وأقل الموديلات المنفذة ِِّ تحقيق الناحية الوظيفية هو الموديل (r).

الفرض الثاني: توجد فروق ذات دلالة إحصائية بين الموديلات المنفذة فِ تحقيق الناحية الجمالية

$$
\text { وفقا لآراء المحكمين. }
$$

وللتحقق من هذا الفرض تم حساب تحليل التباين لمتوسط درجات الموديلات المنفذة ِيِ

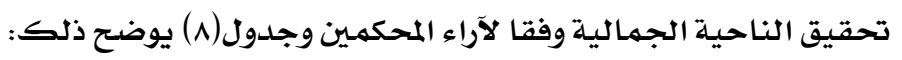

\begin{tabular}{|c|c|c|c|c|c|}
\hline الدلالة & قيمة "ف" & متوسط المربعات & درجة الحرية & مجموع المربعات & الناحية الجمالية \\
\hline \multirow[t]{3}{*}{.264} & \multirow[t]{3}{*}{1.381} & 5.971 & 4 & 23.886 & بين المجموعات \\
\hline & & 4.324 & 30 & 129.714 & داخل المجموعات \\
\hline & & & 34 & 153.600 & المجموع \\
\hline
\end{tabular}

جدول(^) : تحليل التباين لمتوسط درجات الموديلات المنفذة فو تحقيق الناحية الجمالية وفقا لآراء المحكمين.

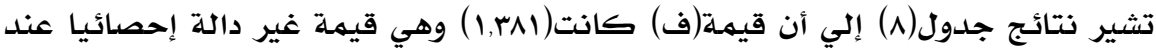

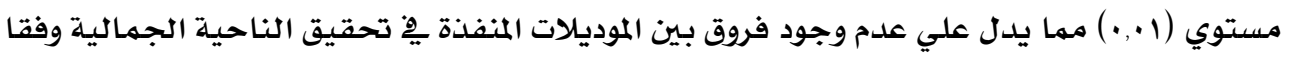

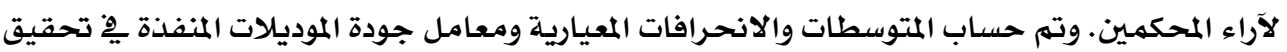

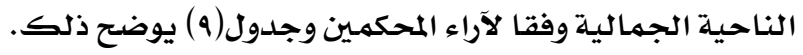


مجلة بحوث التربية النوعية - علد

جدول(ه): المتوسطات والانحرافات المعيارية ومعامل الجودة لدرجات الموديلات المنفذة يو تحقيق الناحية الجمالية وفقا لآراء المحكمـين.

\begin{tabular}{|c|c|c|c|c|}
\hline الترتيب & معامل الجودة & الانحراف المعياري & المتوسط & الموديل \\
\hline 3 & 93.33 & 1.41 & 42.00 & الموديل \\
\hline 5 & 90.16 & 3.69 & 40.57 & الموديل r \\
\hline 4 & 91.43 & 1.68 & 41.14 & الموديل r \\
\hline 1 & 94.60 & 0.79 & 42.57 & الموديل ع \\
\hline 2 & 94.92 & 1.60 & 42.71 & الموديل ه \\
\hline
\end{tabular}

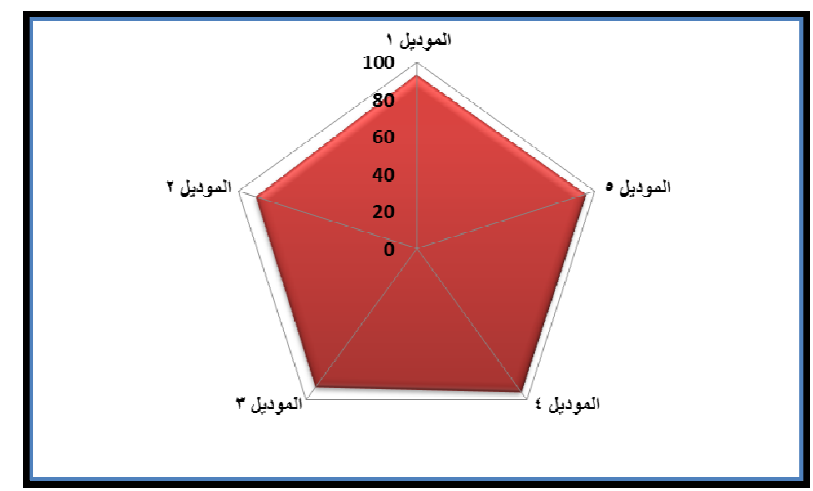

شكل(1) يوضح معامل الجودة لدرجات الموديلات المنفذة يِ تحقيق الناحية الجمالية وفقا لآراء المحكمين.

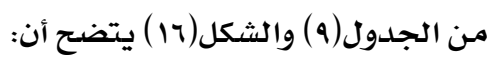

فنجد أن أفضل الموديلات المنفذة ِِّ تحقيق الناحية الجمالية، وفقا لآراء المحكمـين التصميهم

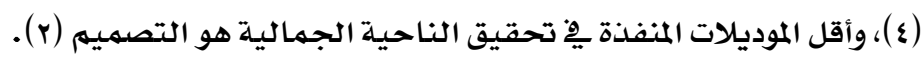

الفرض الثالث: توجد فروق ذات دلالة إحصائية بين الموديلات المنفذة ِِِ تحقيق مستوي الجودة وفقا لآراء المحكمين" توجل فروق دات د

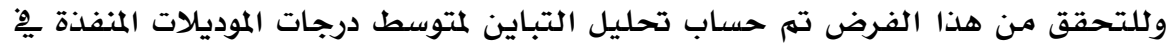

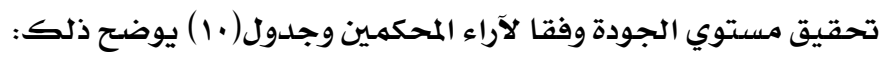

\begin{tabular}{|c|c|c|c|c|c|}
\hline الدلالة & قيمة "ف" & متوسط المربعات & درجة الحرية & مجموع المربعات & مستوي الجودة \\
\hline \multirow[t]{3}{*}{.131} & \multirow[t]{3}{*}{1.929} & 7.071 & 4 & 28.286 & بين المجموعات \\
\hline & & 3.667 & 30 & 110.000 & داخل المجموعات \\
\hline & & & 34 & 138.286 & المجموع \\
\hline
\end{tabular}

جدول ( ـ ): تحليل التباين لمتوسط درجات الموديلات المنفذة ف2 تحقيق مستوي الجودة وفقا لآراء المحكمين. 
تشير نتائج جدول (1) إلي أن قيمة (ف) كانت (1,949) وهي قيمـة غير دالة إحصائيا عند

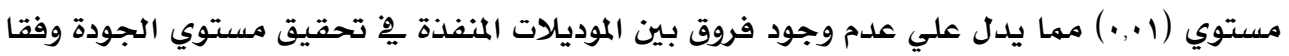

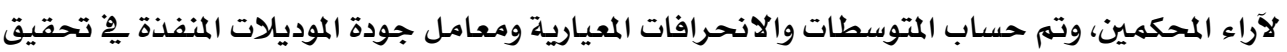

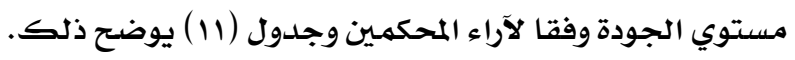

جدول(11): المتوسطات والانحرافات المعيارية ومعامل الجودة لدرجات الموديلات المنفذة فِ تحقيق مستوي الجودة وفقا لآراء المحكمين.

\begin{tabular}{|c|c|c|c|c|}
\hline الترتيب & معامل الجودة & الانحراف المعياري & المتوسط & الموديل \\
\hline 1 & 96.51 & 2.07 & 43.43 & الموديل 1 \\
\hline 3 & 92.70 & 1.80 & 41.71 & الموديل r \\
\hline 4 & 90.48 & 2.43 & 40.71 & الموديل r \\
\hline 2 & 94.29 & 1.99 & 42.43 & الموديل ؛ \\
\hline 2 & 94.29 & 0.98 & 42.43 & الموديل ه \\
\hline
\end{tabular}

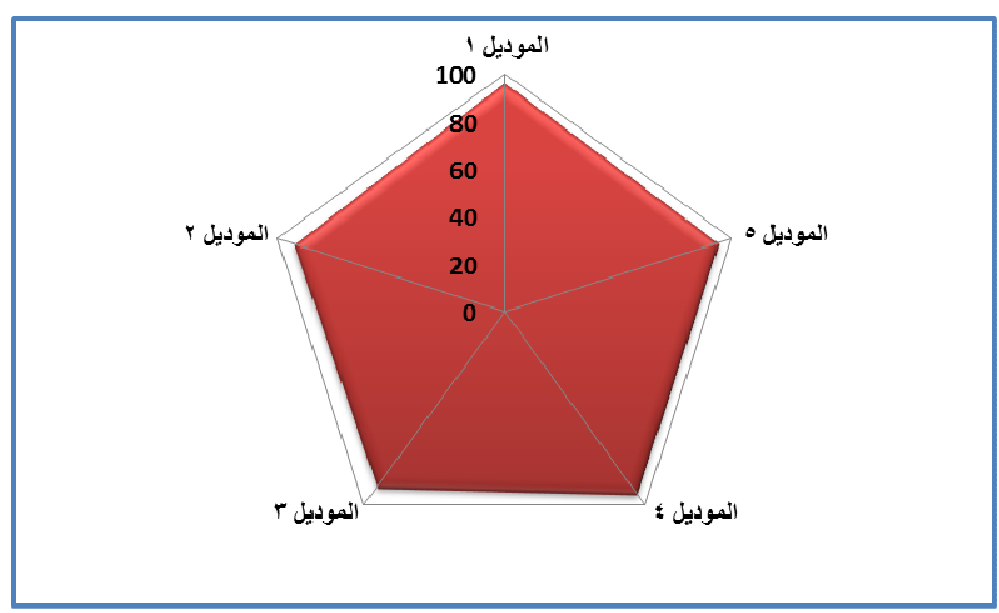

شكل (IV) يوضح معامل الجودة لدرجات الموديلات المنفذة يِّ تحقيق مستوي الجودة وفقا لآراء المحكمين.

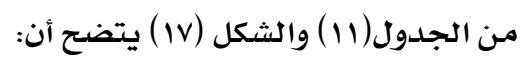

فنجد أن أفضل الموديلات المنفذة يِّ تحقيق مستوي الجودة، وفقا لآراء المحكمين الموديل(1)،

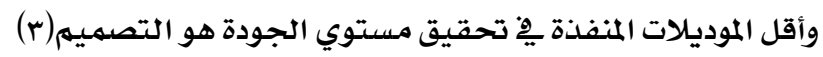

الفرض الرابع: توجد فروق ذات دلالة إحصائية بين الموديلات المنفذة وفقا لآراء المحكمين " وللتحقق من هذا الفرض تم حساب تحليل التباين لمتوسط درجات الموديلات المنفذة وفقا

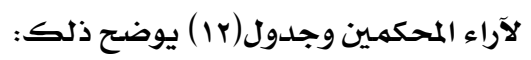


مجلة بحوث التربية النوعية - علدد

جدول(Y ) : تحليل التباين لمتوسط درجات الموديلات المنفذة وفقا لآراء المحكمين

\begin{tabular}{|c|c|c|c|c|c|}
\hline الدلالة & قيمة "ف" & متوسط المربعات & درجة الحرية & مجموع المربعات & المجموع \\
\hline \multirow[t]{3}{*}{.007} & \multirow[t]{3}{*}{3.745} & 15.667 & 4 & 62.667 & بين المجموعات \\
\hline & & 4.184 & 100 & 418.381 & داخل المجموعات \\
\hline & & & 104 & 481.048 & المجموع \\
\hline
\end{tabular}

تشير نتائج جلدول (rا) إلي أن قيمة (ف) كانت (r,V\&0) وهي قيمة دالة إحصائيا عند

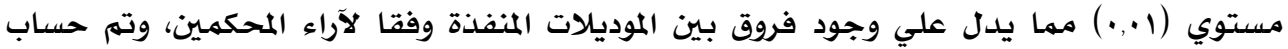

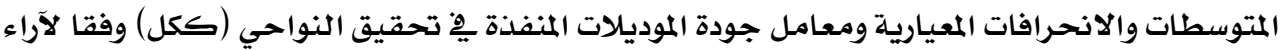

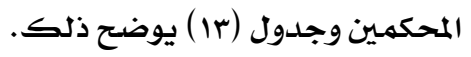

جلدول(rا ) : المتوسطات والانحرافات المعيارية ومعامل الجودة لدرجات الموديلات المنفذة وفقا لآراء المحكمين.

\begin{tabular}{|c|c|c|c|c|}
\hline ترتيب الموديلات & معامل الجودة & الانحراف المعياري & المتوسط & الموديل \\
\hline 2 & 94.92 & 2.17 & 42.71 & الموديل 1 \\
\hline 4 & 91.96 & 2.71 & 41.38 & الموديل r \\
\hline 5 & 91.01 & 2.25 & 40.95 & الموديل r \\
\hline 3 & 94.71 & 1.47 & 42.62 & الموديل ؛ \\
\hline 1 & 95.13 & 1.29 & 4281. & الموديل ه \\
\hline
\end{tabular}

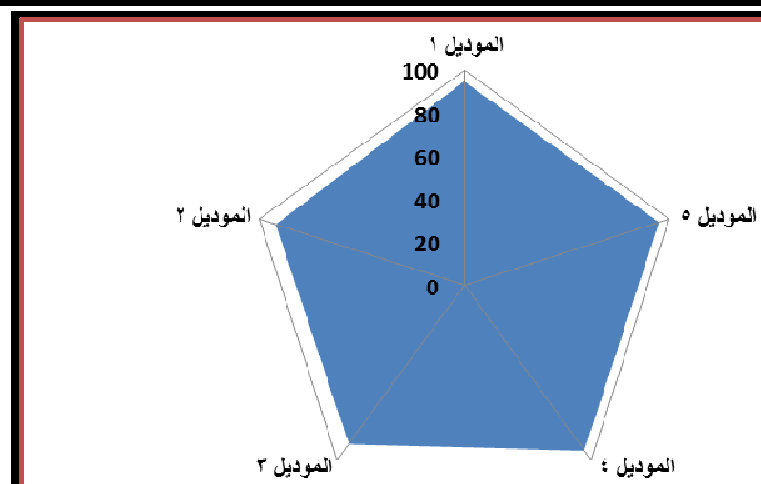

شكل (1 ) يوضح معامل الجودة لدرجات الموديلات المنفذة وفقا لأراء المحكمين.

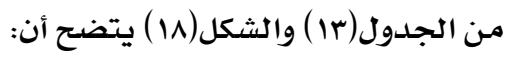

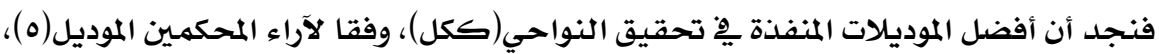

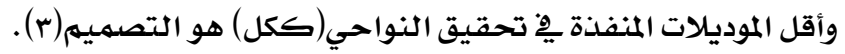




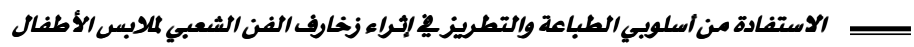

الفرض الخامس: توجد فروق ذات دلالة إحصائية بين محاور تقييم الموديلات المنفذة وفقا لآراء المحكمين " توجل فرق

وللتحقق من هذا الفرض تم حساب تحليل التباين لمتوسط درجات محاور تقييم الموديلات

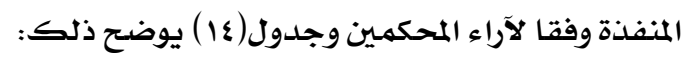

جدول(ع) ): تحليل التباين لمتوسط درجات الموديلات المنفذة وفقا لآراء المحكمين

\begin{tabular}{|c|c|c|c|c|c|}
\hline الدلالة & قيمة "ف" & متوسط المربعات & درجة الحرية & مجموع المربعات & المجموع \\
\hline \multirow[t]{3}{*}{.570} & \multirow[t]{3}{*}{.566} & 2.638 & 2 & 5.276 & بين المجموعات \\
\hline & & 4.664 & 102 & 475.771 & داخل المجموعات \\
\hline & & & 104 & 481.048 & المجموع \\
\hline
\end{tabular}

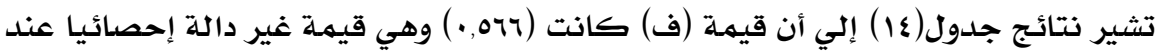

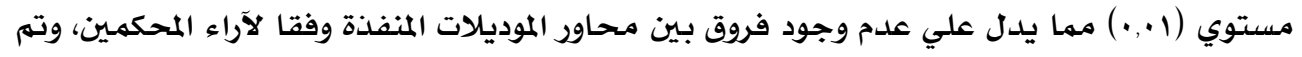

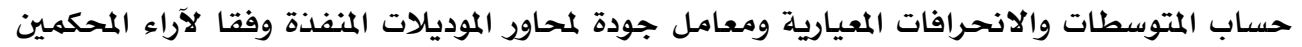
وجدول (ع أ) يوضح ذلك.

جدول(10) : المتوسطات والانحرافات المعيارية ومعامل الجودة لدرجات محاور الموديلات المنفذة

\begin{tabular}{|c|c|c|c|}
\hline معامل الجودة & الانحراف المعياري & المتوسط & المحور \\
\hline 94.10 & 2.33 & 42.34 & الناحية الوظيفية \\
\hline 92.89 & 2.13 & 41.80 & الناحية الجمالية \\
\hline 93.65 & 2.02 & 42.14 & مستوي الجودة \\
\hline
\end{tabular}

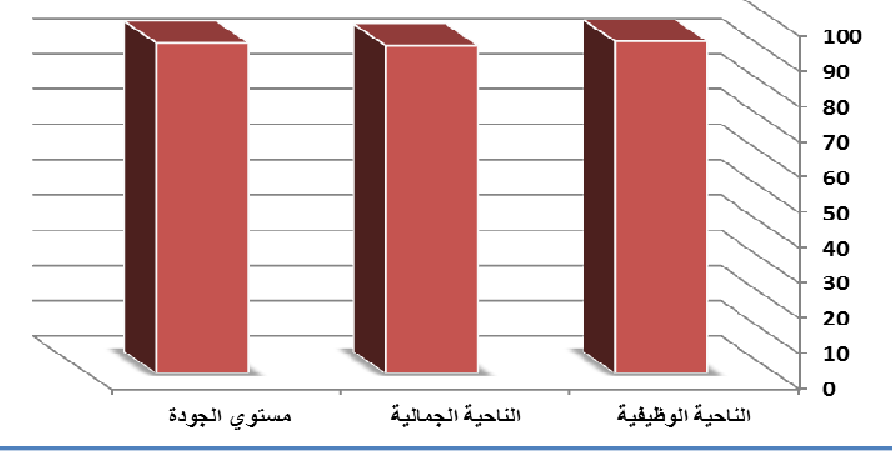

شكل (19) يوضح معامل الجودة لمحاور الموديلات المنفذة وفقا لأراء المحكمين.

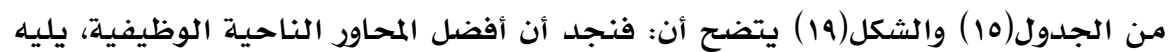
مستوي الجودة، يليه الناحية الجمالية. 
مجلة بحوث التربية النوعية - علد

ثانيا: ثتائج استبيان تقيييم المنتجات الموجه إلى المستهلكين: الفرض السادس: توجد فروق ذات دلالة إحصائية بين الموديلات المنفذة وفقا لآراء المستهلكين. وللتحقق من هذا الفرض تم حساب تحليل التباين لمتوسط درجات الموديلات المنفذة وفقا لآراء المستهلكين وجدول(17) يوضح ذلك: هن:

جدول(1) ): تحليل التباين لمتوسط درجات الموديلات المنفذة وفقا لآراء المستهلكين

\begin{tabular}{|c|c|c|c|c|c|}
\hline الدلالة & قيمة "ف" & متوسط المربعات & درجة الحرية & مجموع المربعات & المجموع \\
\hline \multirow[t]{3}{*}{.019} & \multirow[t]{3}{*}{3.245} & 76.982 & 4 & 307.927 & بين المجموعات \\
\hline & & 23.724 & 50 & 1186.182 & داخل المجموعات \\
\hline & & & 54 & 1494.109 & المجهوع \\
\hline
\end{tabular}

تشير نتائج جدول (17) إلي أن قيمة (ف) كانت (ب0,Y) وهي قيمة دالة إحصائيا عند

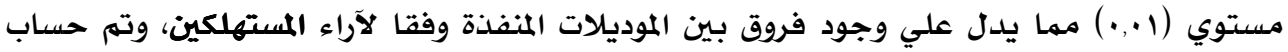

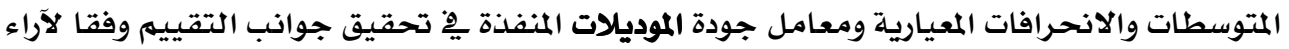
المستهلكين وجدول (IV) يوضسح ذلك.

جدول(IV) : المتوسطات والانحرافات المعيارية ومعامل الجودة لدرجات الموديلات المنفذة وفقا لآراء المستهلكين.

\begin{tabular}{|c|c|c|c|c|}
\hline ترتيب الموديلات & معامل الجودة & الانحراف المعياري & المتوسط & الموديل \\
\hline 2 & 96.67 & 3.48 & 147.91 & الموديل 1 \\
\hline 4 & 93.46 & 7.51 & 143.00 & الموديل r \\
\hline 5 & 95.31 & 3.97 & 145.82 & الموديل r \\
\hline 1 & 98.10 & 3.86 & 150.09 & الموديل ؛ \\
\hline 3 & 96.43 & 4.41 & 147.55 & الموديل 0 \\
\hline
\end{tabular}

شكل( • ) يوضح معامل الجودة لدرجات الموديلات المنفذة وفقا لآراء المستهلكين.

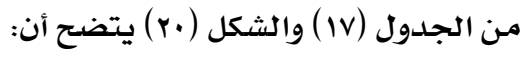




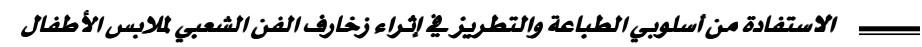

فنجد أن أفضل الموديلات المنفذة يِ تحقيق جوانب التقييم وفقا لآراء المستهلكين الموديل(ع)،

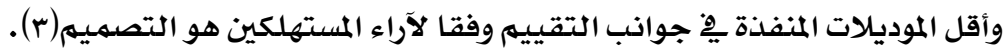

ثالثا: تتائج المقابلات الفردية لعينة من أطفال المرحلة المثلة المتوسطة.

جدول (11) معامل اتفاق الأطفال علي الموديلات المنفذة من بعض عناصر الفن الشعبي

\begin{tabular}{|c|c|c|c|c|c|c|c|c|c|c|c|c|}
\hline \multirow[t]{2}{*}{ |الترتيب } & \multirow{2}{*}{ الاتفاق } & \multicolumn{2}{|c|}{ الترتيب الخامس } & \multicolumn{2}{|c|}{ الترتيب الرابع } & \multicolumn{2}{|c|}{ الترتيب الثالث } & \multicolumn{2}{|c|}{ الترتيب الثاني } & \multicolumn{2}{|c|}{ الترتيب الأول } & \\
\hline & & $\%$ & العدد & $\%$ & العلد & $\%$ & العلد & $\%$ & العلد & $\%$ & العدد & \\
\hline 3 & 209 & 0.00 & & 5.88 & 3 & 27.45 & 14 & 17.65 & 9 & 49.02 & 25 & الموديل الأول \\
\hline 5 & 188 & 5.88 & 3 & 15.69 & 8 & 17.65 & 9 & 25.49 & 13 & 35.29 & 18 & الموديل الثاني \\
\hline 2 & 213 & 0.00 & & 9.80 & 5 & 15.69 & 8 & 21.57 & 11 & 52.94 & 27 & الموديل الثالث \\
\hline 1 & 228 & 0.00 & & 0.00 & & 17.65 & 9 & 17.65 & 9 & 64.71 & 33 & الموديل الرابع \\
\hline 4 & 202 & 0.00 & & 11.76 & 6 & 19.61 & 10 & 29.41 & 15 & 39.22 & 20 & لموديل الخامس \\
\hline
\end{tabular}

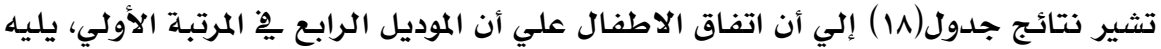

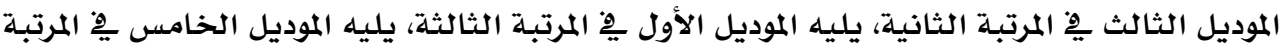

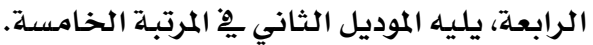
رابعا: مناقشة العلاقة الارتباطية بين تتائج البحث في ضوء آراء المحكمين، وآراء عينة البحث من المستهلكين وآراء الأطفار.

الفرض السابع: توجد علاقة ارتباطية بين ترتيب المحكمين والمستهلكين، والأطفال للموديلات المنفذة

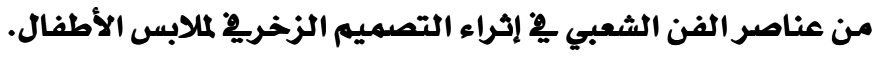

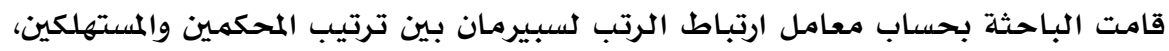

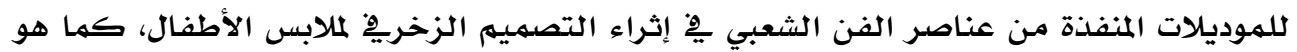

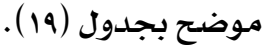

جدول(19) معامل ارتباط الرتب لسبيرمان لمعرفة العلاقة الارتباطية بين ترتيب المحكمين والمستهلكين،

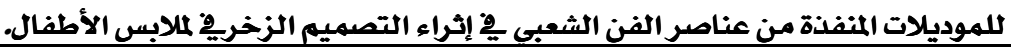

\begin{tabular}{|c|c|c|c|c|c|c|c|}
\hline \multicolumn{4}{|c|}{ معامل ارتباط الرتب لسبيرمان } & ترتيب الأطفال & ترتيب المتهلكين & ترتيب المحكمين & الموديلات \\
\hline أطفال & مستهلكين & محكمين - & & & & & \\
\hline $0.20 *$ & $0.60 * *$ & 1 & محكمين & 3 & 2 & 2 & 1 \\
\hline $0.40 *$ & 1 & & مستهلكين & 5 & 4 & 4 & 2 \\
\hline \multirow[t]{3}{*}{1} & & & أطقال & 2 & 5 & 5 & 3 \\
\hline & & & & 1 & 1 & 3 & 4 \\
\hline & & & & 4 & 3 & 1 & 5 \\
\hline
\end{tabular}




$$
\text { تشير نتائج الجدول إلي أن: }
$$

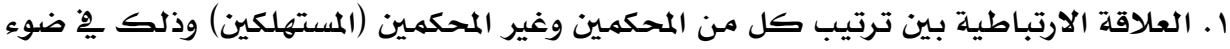

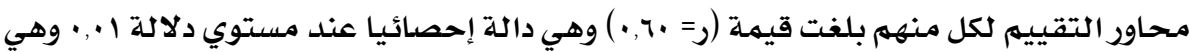

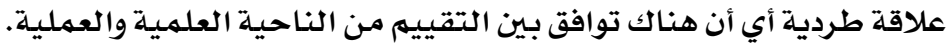

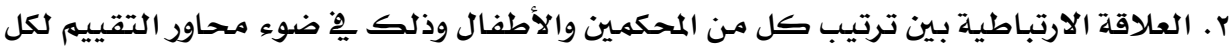

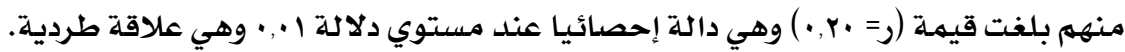

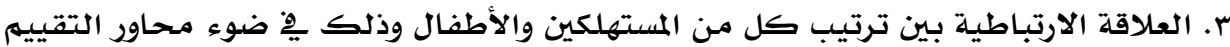

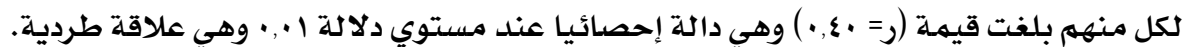

$$
\text { وبذلك يمكن للباحثة قبول الفرض الذي ينص علي: }
$$

توجد علاقة ارتباطيـة بـين ترتيب المحكمـين والمستهلكين، للمـوديلات المنفـذة مـن عناصـر الفـن

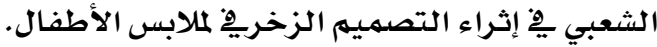

\section{ملفص النتتائه:}

ا . توجد فروق ذات دلالة إحصائية بين الموديلات المنفذة ِِّ تحقيق الناحية الوظيفية وفقا لآراء

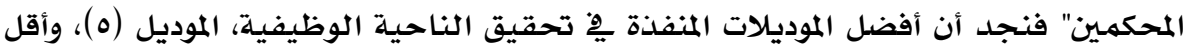

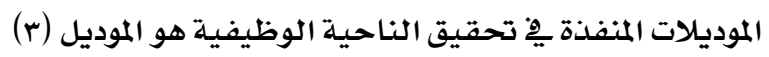

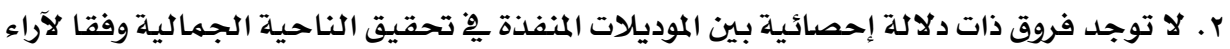

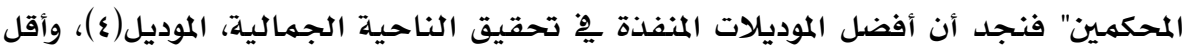

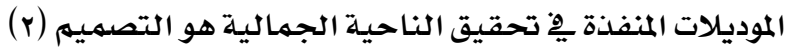

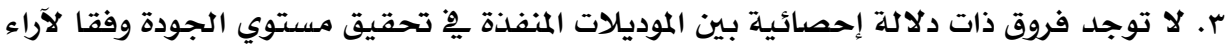

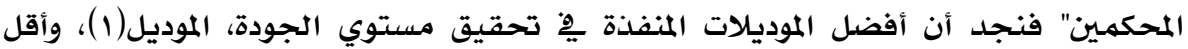

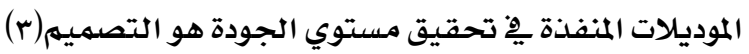

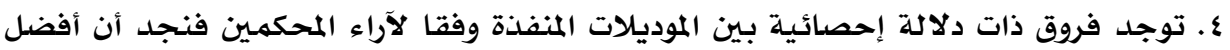

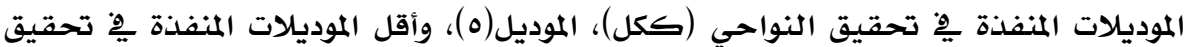
النواحي (ككل) هو التصميم (r). ه. لا توجد فروق ذات دلالة إحصائية بين محاور تقييم الموديلات المنفذة وفقا لآراء المحكمين "

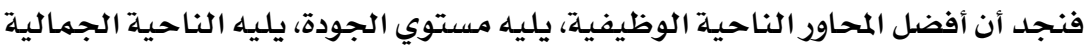

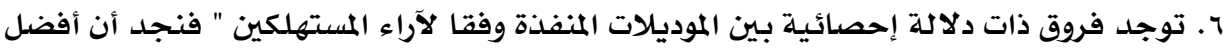

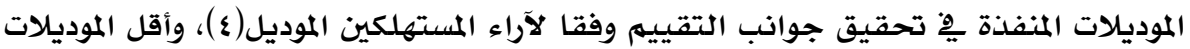

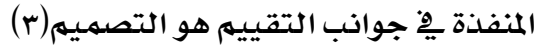

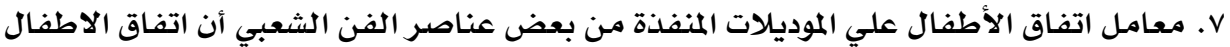

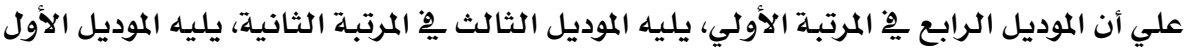


ِِّ المرتبة الثالثة، يليه الموديل الخامس ِِ المرتبة الرابعة، يليه الموديل الثاني ِِِ المرتبة

الخامسة.

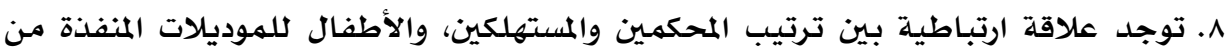

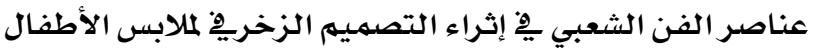

التوصيات:

ا ـ الاهتمام بدراسة التراث للمحافظة عليه من الاندثار.

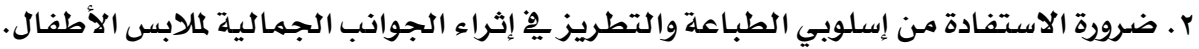

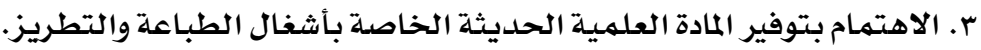

المراجع: (2)

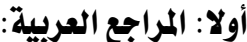

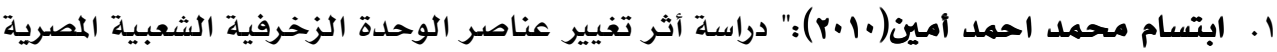

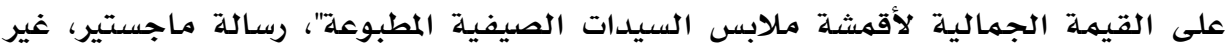

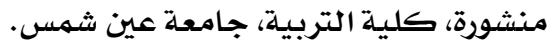

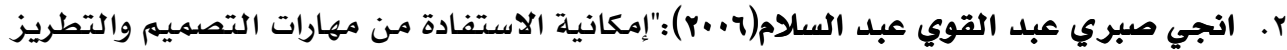

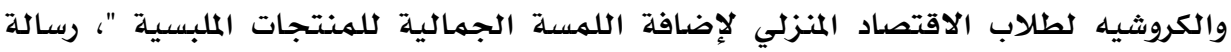
ماجستير غير منشورة، كلية الاقتصاد المنزلي، جامعلة المادية المنوفية.

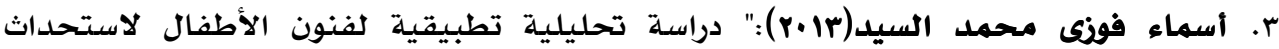
تصميمات جلديدة لملابس الأطفال ومكملاتها "، رسالة ماجستير، غير منشورة، كلية الاقتصاد

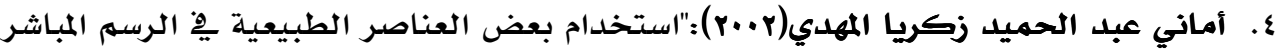

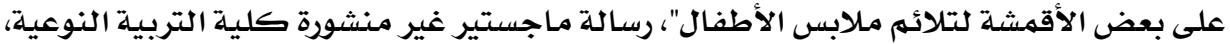

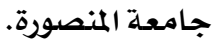

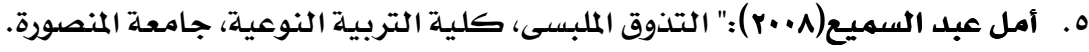

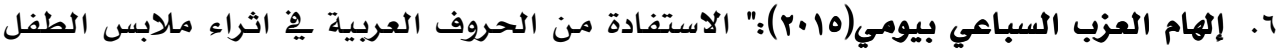

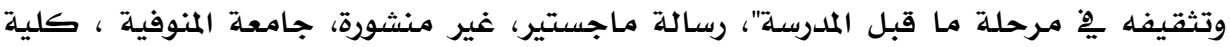
الاقتصاد المنزلي.

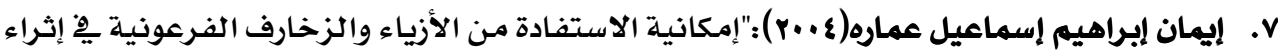

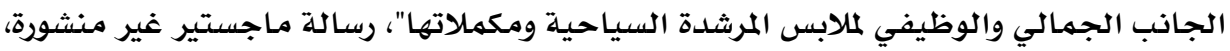
كلية الاقتصاد المنزلي، جامعة المنوفية المبية.

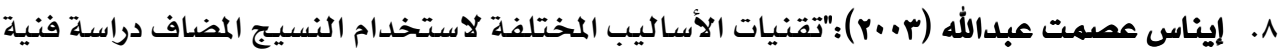
تطبيقية مقارنة"، رسالة دكتوراه غير منشورة ، كلية الاقتصاد المنزبي، جامعة حلوان. 
مجلة بحوث التربية النوعية - علد

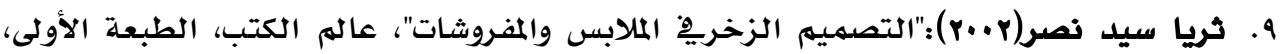
القاهرة .

• . ثناء على رجب حجى(Yl •r): "إثراء التصميهم الزخرفى لزى الطفل المصري باستخدام برامـج الحاسب الآلي، رسالة دكتوراه غير منشورة، كلية التربية النوعية، جـامعة المنصورة. 11 . حسن على حمودة(1919):"فن الزخرفة "، الهيئة المصريـة العامـة للكتاب.

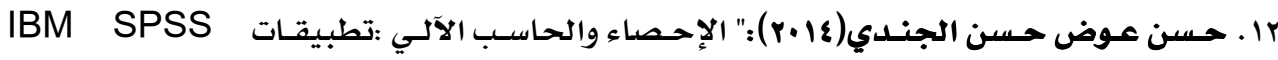
Statistics V21

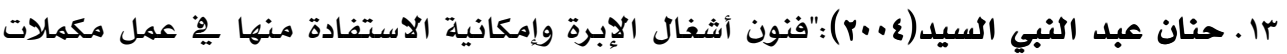
الملابس"، رسالة ماجستير غير منشورة، كلية الاقتصـاد المنزلي، جامعة المنوفية.

ع ا . سعاد ماهر(1979) :"مشهد الامام علي يِّ النجف وما بـه من هدايا وتحف "، دار المعارف، القاهرة.

$$
10
$$

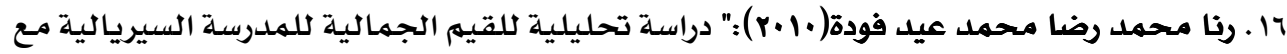
استخدام اسـاليب متنوعة من التطريز والطباعة لعمل تصميمات ل تي شيرت الاطفال"، رسالة ماجستير، غير منشورة، كلية التربية النوعيـة، جامعة طنطا. IV . رثا عباس محمد متولى الجوهري(7 +.r):" استخدام بعض أساليب التطريز وعلاقتها بالملائمهة الوظيفية لملابس الطفل"، رسالة دكتوراه غير منشورة، كلية التربية النوعية، جامعة المنصورة.

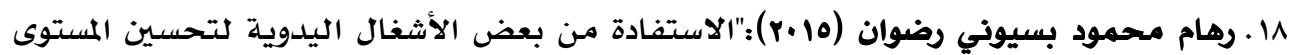
الاقتصادي لكلأسرة المصريـة"، رسالة ماجستير غير منشورة، كلية التربية النوعية، جامعة رهية المنصورة.

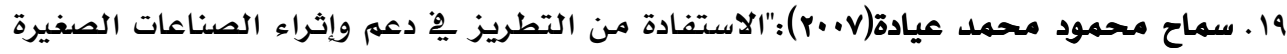
بمـحافظة المنوفية "، رسالة مـاجستير غير منشورة، كلية الاقتصاد المنزلي، جامعة المنوفية. • · . سنية خميس صبحي رضوان(1991) :"تطويع الزخارف الفرعونية لخدمة الإعلام السياحي "رسانة دكتوراه غير منشورة ،كلية الاقتصاد المنزلي جامعة حلوان.

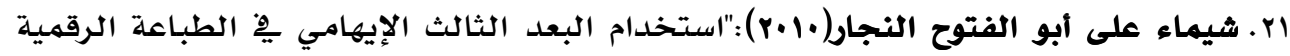
لاستحداث معلقات طباعية ٍِِ ضوء معايير ضمان الجودة والاعتماد"، رسانة ماجستير غير منشورة، كلية التربية النوعية، جامعة المنصورة. r . ع صافيناز سمير محمد (r. •r):" استحداث وحدات زخرفية معاصرة وتطبيقها بأساليب التطريز والطباعة معا لإثراء جماليات ملابس الطفل"، رسالة ماجستير غير منشورة، كلية الاقتصاد المنزلي، جامعة المنوفيـة.

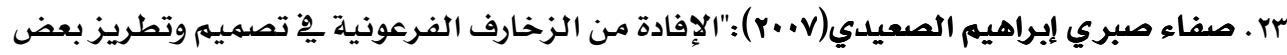
القطع الملبسية لدعهم صناعة السياحة يخ مصر"، رسالة دكتوراه غير منشورة، كلية التربية النوعية، جامعة المنصورة. 
ع . عبد التواب يوسف(1997) )" الطفل العربي والفن الشعبي"، الدار المصرية اللبنانية، الطبعة الأولى،

القاهرة.

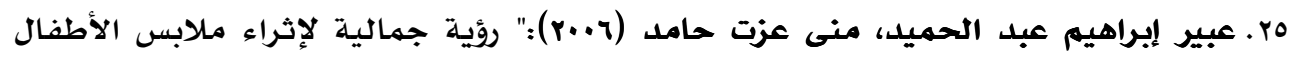

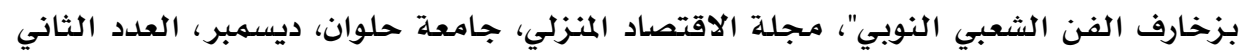

$$
\text { والعشرون. }
$$

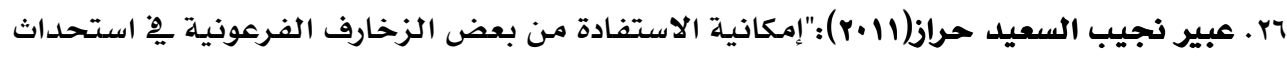

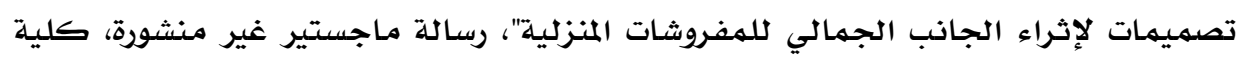
التربية النوعيلة، جامعة المنصورة.

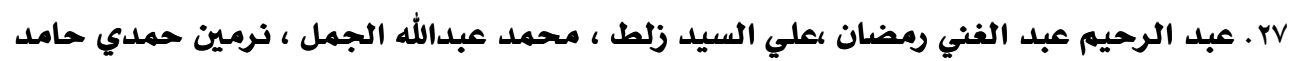

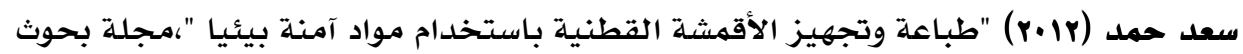

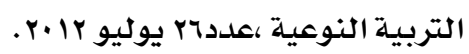

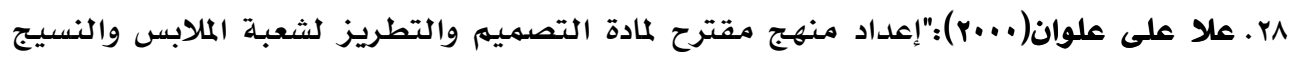

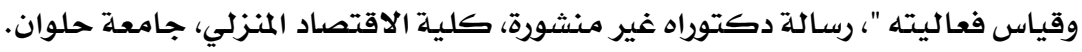

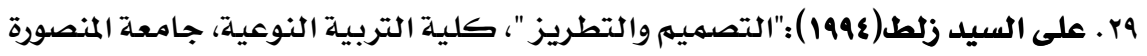

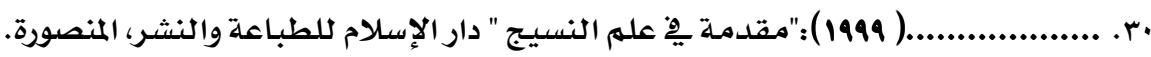

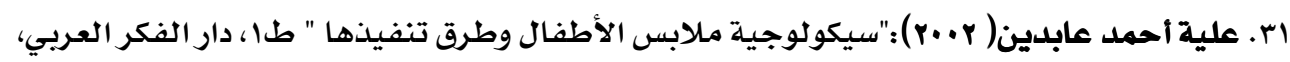
القاهرة.

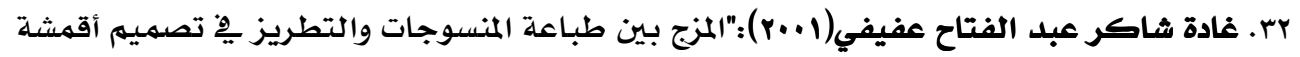

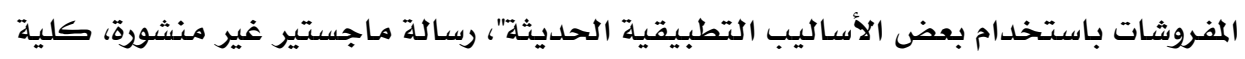

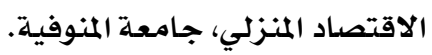

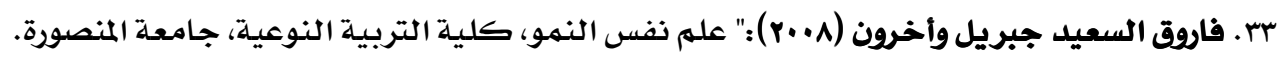

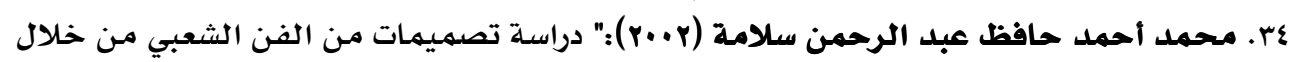

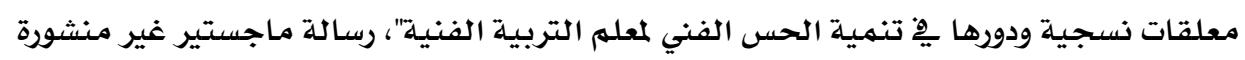
كلية التربية النوعية، جامعة المنصورة.

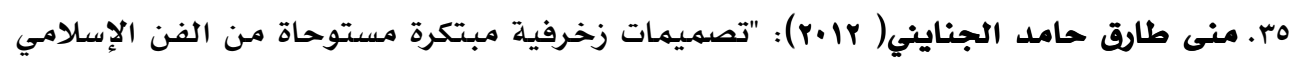

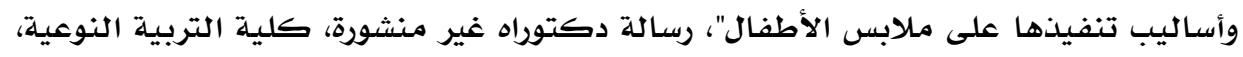
جامعة المنصورة.

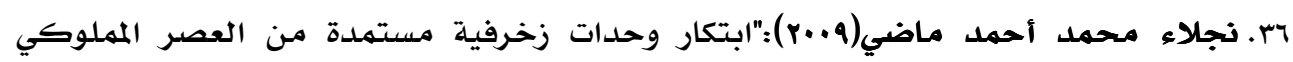

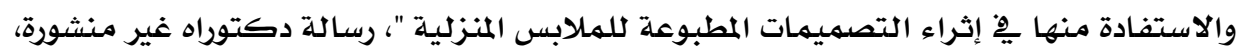

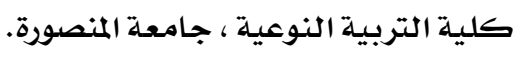

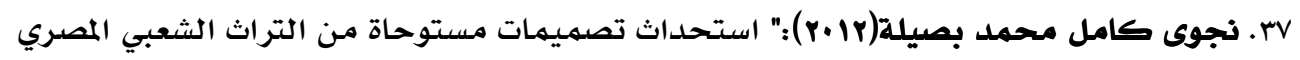

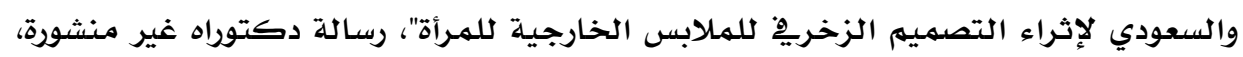


مجلة بحوث التربية النوعية - علدد

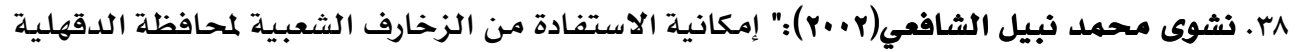

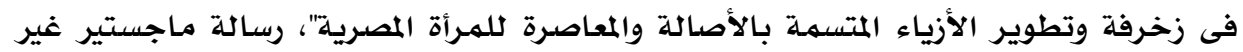

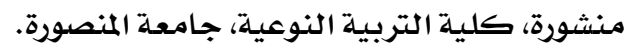

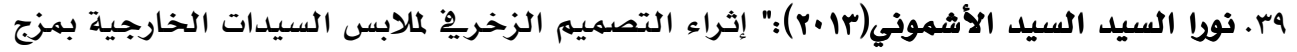

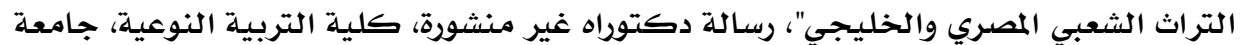

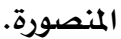

•ـ. يوسف خليفة غراب، ونجوى حسين حجازي(r.rr):" جماليات الزخارف الشعبية رؤيـة لتنمية

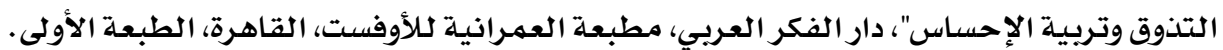

ثانيا: المراجع الأجنبية: اتئية

1. Enthoven Jacqueline,(1964): "The Stitches of Creative embroidery". New York Van nostnanol reinhold company.

2. John, Edith,(1973):"Creative Stitches" Dover Publications, Inc New York.

3. word ,Lock (1962):"The complete book of Needle Work" word, Lack co .Limited England, London.

ثالثا: مواقع الانترنت:

4. https://crafty4all.com/archives/5308 at 28/1/2107 1:38Bm

5. https://www.pinterest.com/pin/474918723191478446 at 28/1/20171:55.

6. http://legrenierdebibiane.com/Broderie/point de bouclette.html at28/1/2017 1:5.

7. https://forum.hawahome.com/t190207.html at 28/1/2017 1:50

8. http://www.bntmofeid.com/vb/showthread.php?t=17144 at 28/1/2017 2:09.

9. http://www.iza-broderie.com/pages/les-principaux-points-de-broderie at 28/1/20171:45.

10. http://ito.vspu.net/ENK/TIMTPN/webquest_2011/Bilohvostukova_Mel nuk Frasunyk/t.2.1.hm at 28/1/2017 10:56.

11. http://www.stooob.com/646247.html at28/1/2017 2: 10 .

12. -http://www.qassimy.com/vb/showthread.php?t=233739 at $18 / 1 / 2017$ 11:04AM. 


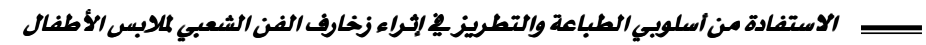

Benefiting from the Two Methods of Embroidery and Printing in Enriching the Folk Art Ornaments in Children Clothes

\section{Abstract}

Recently, it has been noticed that the children clothes in the stage of Middle Childhood tend to the western tradition, whether in the clothes' design or in the ornaments on these clothes, which is contradictory to our society and the Egyptian identity. In this regard, the researcher was motivated to select this specific study; thus, from this point of view, this current study is based on the Folk Art with its different ornaments, and how a fashion designer could benefit from it; and that is in order to advance the clothes industry, improve the aesthetic sense, and maintain our Egyptian identity.

In this context, this current research is concerned with benefiting from the two methods of Embroidery and Printing in enriching the ornamental design inspired from some Folk Art units with respect to children clothes in the stage of Middle Childhood. Thus, in this study, (5) models of children clothes were executed, and an Evaluation Form was prepared for the executed products, which were presented to (15) arbitrators specialized in this specialty, in order to judge the success of these executed designs. In addition, an Evaluation Form was prepared for the consumers' sample of (51) mothers, in order to judge the success of the executed designs.

The research concluded that there are statistically significant differences between the executed models, with regard to achieving the functional aspect; however, there are no differences between the executed models, with regard to achieving (the aesthetic aspects - the performance quality level). In addition, there are no statistically significant differences between the axes of assessing the executed models; however, there are statistically significant differences between the executed models according to the views of the consumers. Furthermore, there is a correlation between the order of arbitrators, consumers and children for these models, which have been executed from elements of the Folk Art in order to enrich the ornamental design of children clothes. 
مجلة بحوث التربية النوعية - عدد IV - ميوليو

\title{
الملاحق
}

هلمق (1)

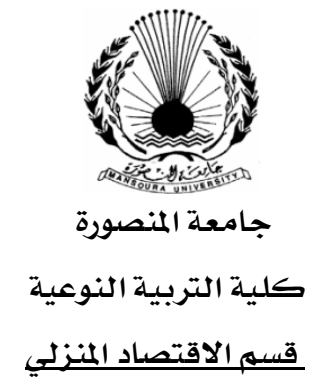

استمارة تقييم ملابس الطفل المنفذة باستخدام تصميمات من الفز الشعبي

السيد الأستاذ الدكتور السين

\author{
تحية طيبـة وبعد ،"،.،؛ \\ تقوم الباحثة بإعداد رسالة ماجستير بعنوان:
}

الاستفادة من بعض عناصر الفن الشعبي يِّ إثراء التصميم الزخربِ لملابس الأطفال

تستهدف الدراسة دراسة زخارف الفن الشعبي ومحاولـة تطويعها لابتكار تصميمات جديدة

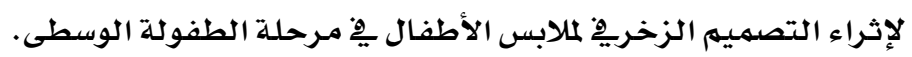

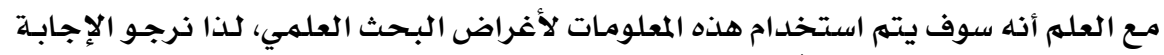

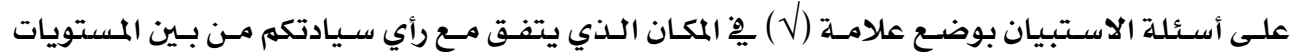

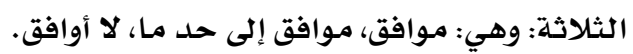

ولسيادتكمم جزيل الشكر والتقدير

الباحثة :

البيانات : سميحة محمد حافظ

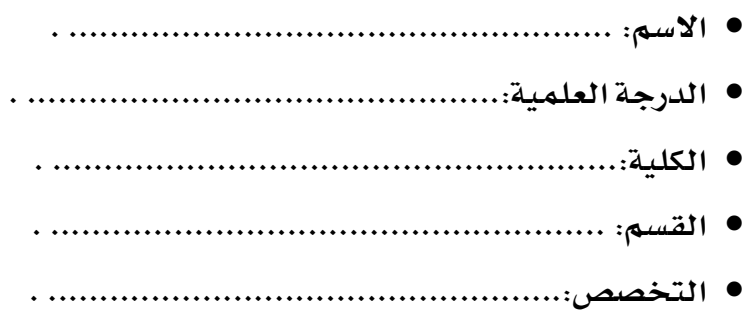




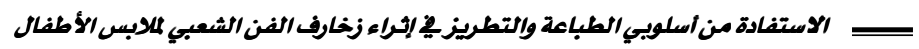

تابع استمارة تقييم ملابس الطفل المنفذة باستخدام تصميمات من الفن الشعبي

\begin{tabular}{|c|c|c|c|}
\hline \multicolumn{3}{|c|}{ مستوى التقييي } & \multirow{4}{*}{ عناصر التقييم } \\
\hline \multicolumn{3}{|c|}{ الموديل رقم ( ) } & \\
\hline 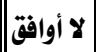 & موافق إلى حلد ما & 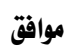 & \\
\hline 1 & r & $r$ & \\
\hline & & & 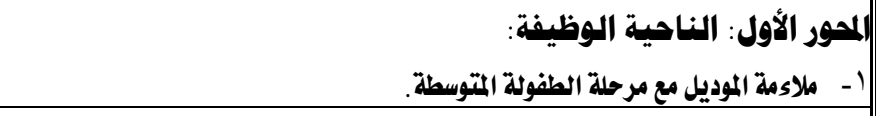 \\
\hline & & & • ملاءهة التقنيات (الطباعة و التطريز) مع مرحلة الطفولة التتوسطة. \\
\hline & & & • • ملاءمة أسلوب الطباعة (الرسم المباشر) مع ملابس الأطفال. \\
\hline & & & 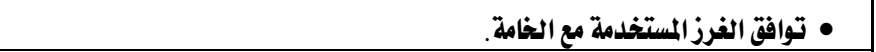 \\
\hline & & & • • تناسب نوع الخيوط المستخدمة مع القماش. \\
\hline & & & • التصميم الزخرفي المنفذ يساهم في تعريف الطفل بالفن الشعبي. \\
\hline & & & • تم إبراز سمات الفن الشعبي بروح معاصرة في المنتج النهائى. \\
\hline & & & المحور الثاني: الناحية الجمالية: \\
\hline & & & • • وجود انسجام وتوافق بين ألوان الطباعة وألوان الموديل. \\
\hline & & & • ملاءمة الفرز المستخدمة للتصميم الزخرفي. \\
\hline & & & • • توافق الفرز المستخدمة مع الشكل النهائي للموديل. \\
\hline & & & • وجود انسجام بين ألوان الخامة وألوان خيوط التطريز. \\
\hline & & & 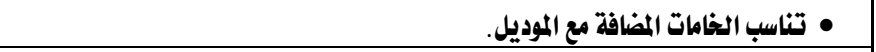 \\
\hline & & & • • تناسب ألوان الخامات المساعدة مع ألوان التقنيات المستخدمة(الطباعة والتطريز). \\
\hline & & & 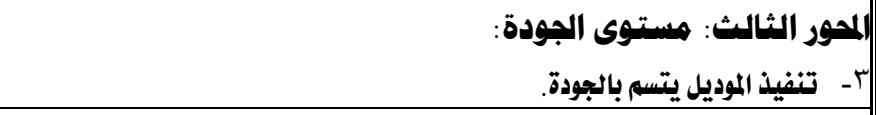 \\
\hline & & & • ملاءمة أبعاد الوحدات الموزعة على الموديل. \\
\hline & & & • • تناسب الألوان المنفذة مع الوحدة الأصلية. \\
\hline & & & • دقة و وضوح التصميم الزخرفي من خلال التقنيات (الطباعة والتطريز) المستخدمة. \\
\hline & & & • والخود تناسق لوني بين جميع مفردات القطعة المنفذة (القماشـــ ألوان الطباعة_ الفرز- \\
\hline & & & • الألوان المستخدمة (البجمنت و الاكريلك) مناسبة للخامة المستخدمة. \\
\hline & & & • • درجة اتتظام الفرز المستخدمة في تنفيذ التقنية. \\
\hline
\end{tabular}


مجلة بحوث التربية النوعية - عدد

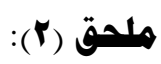

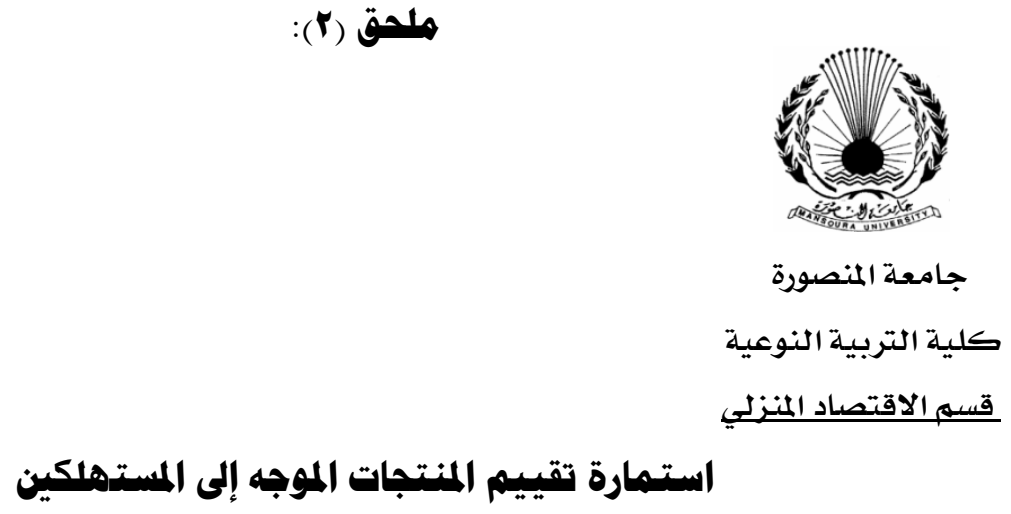

عزيزتي المتتهلكة/

\author{
تحية طيبة وبعد \\ تقوم الباحثة بإعداد رسالة ماجستير بعنوان:
}

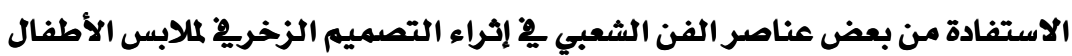

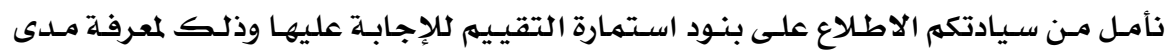

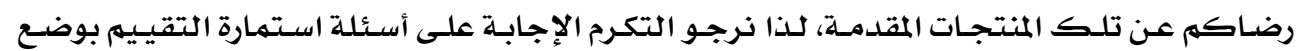

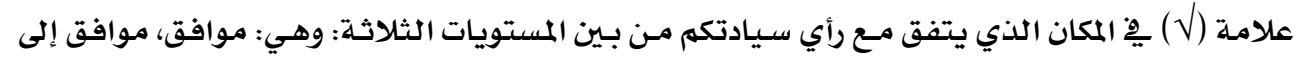
حد ما، لا أوافق.

ولسيادتكم جزيل الشكروالتقدير .،u،u

الباحثة :

البيانات : سميحة محمد حافظ

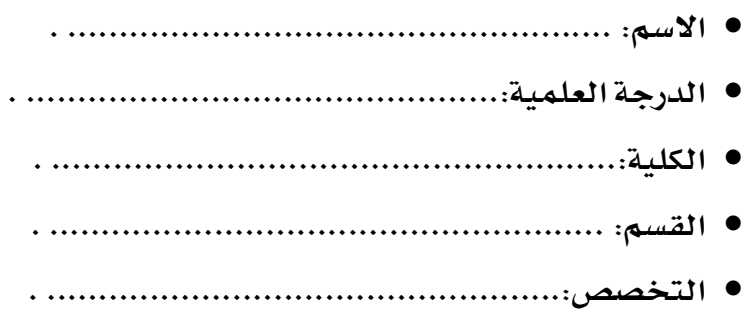




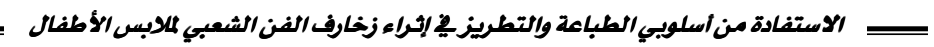

تابع استمارة تقييم المنتجات الموجه إلى المستهلكين

\begin{tabular}{|c|c|c|c|c|}
\hline \multicolumn{3}{|c|}{ مستوى التقييم } & \multirow[b]{3}{*}{ عناصر التقييم } & \\
\hline \multicolumn{3}{|c|}{ الموديل رقم () ( } & & \\
\hline غير موافق & موافق إلى حد ما & موافق & & \\
\hline & & & | ملاكمة النموذج المنفذ للذوق العام. & 1 \\
\hline & & & |ملاكمة النموذج المنفذ للموضة. & r \\
\hline & & & |يضيف التصميه الزخرفي للقطعة الملبسية جمالأ مميزاً. & $r$ \\
\hline & & & التوزيع التصميم الزخرفي مناسب مع المرحلة العمرية المتوسطة للطفل. & $\xi$ \\
\hline & & & يساعد التصميم في تعريف الطفل على أهم الوحدات الزخرفية في الفن الشعبي. & 0 \\
\hline & & & تناسق ألوان التصييم مع القطعة المنفذة. & 1 \\
\hline & & & ساهمت تقنيات (التطريز - الطباعة ) في إثراء الملبس. . & $\checkmark$ \\
\hline & & & يعد التصميه المترح إضافة لتصميمات الخاصة بالأطفال في السوق المصري. & $\Lambda$ \\
\hline & & & يمكن شراء التصميم للطفل لارتدائه. & 9 \\
\hline & & & ملمس التقنيات (الطباعة والتطريز) يساهم في اثراء ملابس الطفل في مرحلة الطفولة المتوسطة. & 1. \\
\hline & & & |الشكل العام للتقنيات (الطباعة والتطريز) يساهم في اثراء التصميم الزخرفي (الفز الشعبي). & 11 \\
\hline
\end{tabular}

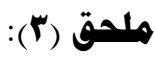

قائمة بأسماء السادة المحكمين لتقييم التصميمات المقترحة والمنتجات المنفذة

\begin{tabular}{|c|c|c|}
\hline الوظيفة وجهة العمل & اسماء السادة المحكمين & $\hat{2}$ \\
\hline استاذ النسيج والملابس- كلية التربية النوعية- جامعة طنطا. & أ.د/ عادل جمال الدين الهنداوي. & 1 \\
\hline أستاذ تصنيع الملابس_ كلية الاقتصاد المنزليـ جامعة حلوان. & أ. د/ أسامة محمد حسين أبو هشيمة. & $r$ \\
\hline استاذ التصميه والتطريز_كلية الاقتصاد المنزلي- جامعة حلوان. & أ.د / سامية أحمد حسن الجارحي. & $r$ \\
\hline أستاذ النسيج والملابس- كلية الاقتصاد المنزلي- جامعة المنوفية. & أ. د/ نشوة عبد الرؤوف عبد الحليم. & $\varepsilon$ \\
\hline أستاذ النسيج والملابس - كلية الاقتصاد المنزليـ جامعة المنوفية . & أ. دـ سالي أحمد أحمد العشماوي. & 0 \\
\hline أستاذ مساعد النسيج والملابس-كلية التربية النوعية - جامعة المنصورة & أ.م.د/ صفاء صبري إبراهيم الصعيدي & 9 \\
\hline أستاذ مساعد النسيج والملابس- كلية التربية النوعية - جامعة طنطا. & أ.م.د/ رانيا محمد أحمد حمودة . & $\checkmark$ \\
\hline استاذ مساعد تصنيع الملابســ كلية الاقتصاد المنزليـ جامعة حلوان. & أ.م.د/ عزيزة أحمد محمد العقلي. & $\wedge$ \\
\hline أستاذ مساعد النسيج والملابس-كلية التربية النوعية - جامعة طنطا. & أ.م.د / آية محمد فوزي لبشتين. & 9 \\
\hline أستاذ مساعد النسيج والملابس- كلية التربية النوعية - جامعة طنطا. & أ. م.د/ هيام دمرداش الفزالي. & $1 \cdot$ \\
\hline استاذ مساعد النسيج والملابسـ كلية التربية النوعيةـ جامعة المنصورة & أ.م.د / نجلاء محمد أحمد ماضي. & 11 \\
\hline استاذ مساعد النسيج والملابس_كلية التربية النوعيةـ جامعة المنصورة. & أ.م.د/ إيرينى سمير مسيحة داود. & ir \\
\hline استاذ مساعد النسيج والملابس_كلية الاقتصاد المنزليـ جامعة المنوفية. & أ. م.د / عبدالله عبد المنعم عبلاتله حسين. & it \\
\hline ملدرس النسيج والملابس-كلية التربية النوعية- جامعة المنصورة . & د/ دعاء محمد سالمان. & $1 \varepsilon$ \\
\hline ملدرس النسيج والملابسـ كلية التربية النوعيةـ جامعة المنصورة. & د / فاطمة جاد محمود سري. & 10 \\
\hline
\end{tabular}

